The following document is a pre-print version of:

Ross P-S, Carrasco-Núñez G, Hayman P (2017) Felsic maar-diatreme volcanoes: a review. Bull. Volc. 79: Article 20 (33 pages)

\title{
Felsic maar-diatreme volcanoes: a review
}

\author{
Pierre-Simon Ross ${ }^{1, *}$, Gerardo Carrasco Núñez ${ }^{2}$, Patrick Hayman ${ }^{3}$ \\ 1. Institut national de la recherche scientifique, 490 rue de la Couronne, Québec (Qc), G1K 9A9, Canada, \\ rossps@ete.inrs.ca \\ 2. Centro de Geosciencias, UNAM, Boulevard Juriquilla 3001, 76230 Querétaro, Qro Mexico, \\ gerardoc@dragon.geociencias.unam.mx \\ 3. Queensland University of Technology, 2 George Street, Brisbane 4000, Australia, patrick.hayman@qut.edu.au \\ * Corresponding author
}

\begin{abstract}
Felsic maar-diatreme volcanoes host major ore deposits but have been largely ignored in the volcanology literature, especially for the diatreme portion of the system. Here we use two Mexican tuff rings as analogues for the maar ejecta ring, new observations from one diatreme, and the economic geology literature on four other mineralized felsic maar-diatremes, to produce an integrated picture of this type of volcano. The ejecta rings are up to $50 \mathrm{~m}+$ thick, and extend laterally up to $\sim 1.5 \mathrm{~km}$ from the crater edge. In two Mexican examples, the lower part of the ejecta ring is dominated by pyroclastic surge deposits with abundant lithic clasts (up to $80 \%$ at Hoya de Estrada). These deposits display lowangle cross-bedding, dune bedforms, undulating beds, channels, bomb sags, and accretionary lapilli, and are interpreted as phreatomagmatic. Rhyolitic juvenile clasts at Tepexitl have only 0-25\% vesicles in this portion of the ring. The upper parts of the ejecta ring sequences in the Mexican examples have a different character: lithic clasts can be less abundant, the grain size is typically coarser, and the juvenile clasts can be different in character (with some more vesicular fragments). Fragmentation was probably shallower at this stage. The post-eruptive maar crater infill is known at Wau and consists of reworked pyroclastic deposits as well as lacustrine and other sediments. Underneath are bedded upper diatreme deposits, interpreted as pyroclastic surge and fall deposits. The upper diatreme and post-eruptive crater deposits have dips larger than 30 degrees at Wau, with approximately centroclinal attitudes. At still lower structural levels, the diatreme pyroclastic infill is largely unbedded; Montana Tunnels and Kelian are good examples of this. At Cerro de Pasco, the pyroclastic infill seems bedded despite about $500 \mathrm{~m}$ of post-eruptive erosion relative to the pre-eruptive surface. The contact between the country rocks and the diatreme is sometimes characterized by country rock breccias (Kelian, Mt Rawdon). Pyroclastic rocks in the diatreme are typically poorly sorted, and ash-rich. They contain a heterolithic mix of juvenile clasts and lithic clasts from various stratigraphic levels. Megablocks derived from the ejecta ring or the country rocks are often found in the diatremes. Evidence for multiple explosions is in the form of steep cross-cutting pyroclastic bodies within some diatremes, and fragments of pyroclastic rocks within other pyroclastic facies. Pyroclastic rocks are cut by coherent felsic dikes and plugs which may have been feeders to lava domes at the surface. Allowing for the difference in magma composition, felsic maar-diatreme volcanoes have many similarities with their ultramafic to mafic equivalents. Differences include a common association with felsic domes, inside the crater or just outside (Wau), although the domes within the crater may be destroyed during the eruption (Hoya de Estrada, Tepexitl); the dikes and plugs feeding and invading felsic diatremes seem larger; the processes of phreatomagmatic explosions involving felsic magmas may be different.
\end{abstract}

\section{Introduction}

Maar-diatremes are the second most common volcano type on continents and islands after scoria cones (Lorenz 2007 and references therein). Maar-diatremes are found in monogenetic volcanic fields and as parasitic vents on larger edifices such as stratovolcanoes. The vast majority 
of documented maar-diatremes were created by eruption of mafic to ultramafic magmas (White and Ross 2011). Felsic maar-diatreme volcanoes, broadly defined as andesitic to rhyolitic (but mostly dacitic to rhyolitic in this review), are less known than their mafic to ultramafic counterparts. In the volcanology literature, a few Quaternary felsic tuff rings have been well described (e.g., Cano-Cruz and Carrasco-Núñez 2008; Austin-Erickson et al. 2011), but apparently no true maars or diatremes (see definitions below). However a number of older felsic maar-diatremes host metallic ores, often epithermal gold-silver deposits (Sillitoe and Bonham 1984) or Cordilleran base metal deposits (Bendezú et al. 2003). Other felsic diatremes cross-cut porphyry-type ore deposits (e.g., Howell and Molloy 1960; Sillitoe 1985; Sillitoe and Angeles 1985; Skewes et al. 2002; Sillitoe et al. 2013). Therefore felsic diatremes have been described in variable detail in the economic geology literature, unknown to most volcanologists. Since the pioneering papers of R.H. Sillitoe and coworkers in the mid-1980s (Sillitoe and Bonham 1984; Sillitoe et al. 1984; Sillitoe 1985; Sillitoe et al. 1985), diatremes have progressively become a relatively widely recognized feature in both porphyry and epithermal systems.

This reviews aims to compile the geology of felsic maardiatreme volcanoes from the best documented examples worldwide, and compare them with their mafic to ultramafic counterparts, with which they have a number of similarities. We use five examples of felsic diatremes from Australia, Indonesia, Papua New Guinea, Peru and the United States. One of these (Wau in Papua New Guinea) also has most of the maar preserved. Other examples of true felsic maars could not be found, so we integrate two Mexican tuff rings, thought to be close cousins to maars, in order to bring in details about the ejecta rings, juvenile pyroclasts and phreatomagmatic fragmentation. The combination of these seven sites allows the general characteristics of felsic maar-diatremes to be distilled and an overview of their eruptive processes to be proposed.

It is hoped that this largely descriptive paper will be useful for economic geologists trying to ascertain whether a particular ore deposit is associated with a diatreme or not, or trying to interpret whether a particular body of coarse fragmental rocks represents a diatreme or another type of 'breccia'. Recognizing that a mineral deposit is hosted by a maar-diatreme volcano, and identifying at which structural level the ore sits in, has multiple implications for exploration. For example, it provides constraints on the probable shape of the body of fragmental rocks hosting mineralization. Also, maar-diatreme volcanoes tend to occur in clusters, so if a diatreme hosts ore, other similar occurrences may be found in the region. Beyond the economic implications, it is anticipated that the review will bring felsic maar-diatremes to the attention of the volcanological community.

\section{Nomenclature and basic concepts}

To avoid ambiguity, and because some readers may not be volcanologists, some definitions and basic explanations are given here.

Phreatomagmatism: an eruptive style in which the magma, of any composition, is fragmented explosively due to interaction with external water (Zimanowski et al. 2015). White and Valentine (2016) discuss how phreatomagmatic products can be distinguished from those of explosive magmatic eruptions (Cashman and Scheu 2015), which do not involve external water.

Maar-diatreme volcano: a small volcano consisting of a crater, a surrounding ejecta (tephra) ring, and a diatreme under the crater (Lorenz 1986; White and Ross 2011 and references therein). The maar crater, by definition, is excavated below the pre-existing ground surface (Lorenz 1973), otherwise the volcano is known as a tuff ring (White and Ross 2011 and references therein). Maarforming eruptions send pyroclasts and fluids into the atmosphere (e.g., Kienle et al. 1980) and their explosive character is largely due to magma meeting aquifers, i.e. subterranean phreatomagmatic activity (e.g., Zimanowski et al. 1991, 1997a; Austin-Erickson et al. 2008; Valentine and White 2012). Many maar-diatreme volcanoes have magmatic explosive phases, or effusive phases, but for the landform to be a maar-diatreme volcano, the dominant eruptive style needs to be phreatomagmatic (White and Ross 2011). The ejecta ring consists of generally wellbedded deposits which, in the mafic to ultramafic examples, are formed mostly by pyroclastic surges and fallout. The beds can be mm to meters in thickness. Some surge deposits display channels, low-angle cross-beds, dunes, or ripples (e.g., Vazquez and Ort 2006; Ross et al. 2011), and many are planar-bedded. Accretionary lapilli are often, but not always, found in the ejecta ring (e.g., Fisher and Waters 1970; Buchel and Lorenz 1993). Pyroclastic flow deposits are rarely reported (e.g., White 1991; White and Schmincke 1999; van Otterloo and Cas 2016). The ejecta ring can also contain ballistic curtains (Graettinger et al. 2015). After the eruption, the crater can become partly to totally filled with lacustrine deposits, resedimented material from the ejecta ring, and/or other sediments (e.g., White 1989; Pirrung et al. 2008). These remobilized or sedimentary deposits are referred to as the post-eruptive crater infill (White and Ross 2011).

Diatreme: the sub-crater portion of a maar-diatreme volcano, consisting of a typically cone-shaped body of mostly pyroclastic rocks, emplaced within pre-existing country rocks. The horizontal diameter of a diatreme is tens of meters to a few thousand meters. The pyroclastic rocks in the diatreme contain both juvenile clasts and lithic fragments (see White and Houghton 2006 for definition of 'pyroclastic', 'lithic', 'juvenile' and the general nomenclature to describe volcaniclastic deposits and rocks). The most common rock type is lapilli tuff to tuff 
breccia (e.g., White 1991; Stiefenhofer and Farrow 2004; Lefebvre et al. 2013; Delpit et al. 2014). In the ultramafic to mafic examples, the pyroclastic rocks can be bedded (e.g., Delpit et al. 2014) or non-bedded (e.g., Lefebvre et al. 2013); when both bedded and non-bedded pyroclastic rocks occur, the bedded ones are generally in the upper portion of the diatreme (White and Ross 2011 and references therein). Subsidence can be an important process operating in the diatreme during the eruption (e.g., Delpit et al. 2014) and after (e.g., Suhr et al. 2006). Diatreme-filling fragmental rocks can be differentiated from other coarse fragmental rocks in which ores can also be found using the following criteria:

- the sorting is relatively poor, i.e. there is a significant proportion of ash ( $\leq 2 \mathrm{~mm})$-grade components as well as some larger clasts;

- $\quad$ there are juvenile fragments, as well as country rock (lithic) clasts;

- the cone-shaped body of pyroclastic rocks was connected to the surface during eruption, as shown by features such as carbonized wood, sinter, pyroclastic surge deposits, and accretionary lapilli (Sillitoe 1985), which can have subsided to deeper final locations; the wood, for example, must have come from the paleosurface, demonstrating that the diatreme was overlain by a crater open to the atmosphere during the eruption. In contrast, in other types of "breccia pipes" found near ore deposits, or hosting ore deposits, such as some hydrothermal breccias, there is no need for a connection to the paleo-surface;

- there is a lack of significant open space between the clasts due to the abundant ash matrix (Sillitoe 1985), whereas some other types of fragmental rocks, such as hydrothermal breccias, are typically clast supported and include cement instead of an ash matrix.

Tuff rings are small volcanoes (e.g., Hoya de Estrada, Tepexitl) that represent close cousins to maars (see Table 3 in White and Ross 2011). They have a similar well stratified ejecta ring. However the crater is not excavated into the pre-existing surface, and the diatreme is thought to be shallower. Lithic fragments are commonly less abundant in tuff rings than in maar ejecta rings, a typical figure mentioned by Lorenz (1986) being 1-5\% lithics, although there are examples with much more (see Hoya de Estrada and Tepexitl below, and footnote 4 in Table 3 from White and Ross 2011). The vast majority of tuff rings are thought to be phreatomagmatic in origin (e.g., Leys 1983; Lorenz 1986; Chough and Sohn 1990; Rottas and Houghton 2012).

Diatreme-dome complex: many felsic maar-diatremes are associated with lava domes or plugs (Cerro de Pasco, Guinaoang, Kelian, Wau). For this reason, these volcanoes have sometimes been called diatreme-dome complexes (e.g., Baumgartner et al. 2009: Cerro de Pasco and two other nearby centers). However, some felsic tuff rings lack preserved domes (Hoya de Estrada, Tepexitl), and this may also apply to felsic maars, so "diatreme-dome complex" is not a generally applicable name.

Megablocks are fragments larger than a few meters across in the diatreme, which can consist of country rocks or subsided pyroclastic deposits. The megablocks are normally surrounded by pyroclastic deposits.

Breccia: a volcanic breccia is a type of volcaniclastic rock containing over $75 \%$ clasts larger than $64 \mathrm{~mm}$ (White and Houghton 2006). This rock type is rare in maar-diatreme volcanoes: block-size fragments rarely form over $75 \%$ of the deposits, which are more typically tuffs, lapilli tuffs and tuff breccias. In the economic geology literature, however, the term breccia can mean a wide range of things, including post-emplacement hydraulic fracturing of coherent rocks and a range of other hydrothermal breccias. Here, when it is believed that the rocks being described are not primary volcaniclastic rocks containing over $75 \%$ clasts larger than $64 \mathrm{~mm}$, they are labelled 'breccia' with the single quotation marks.

Juvenile pyroclast: fragment of solidified magma produced during an eruptive episode that is derived either directly from the magma (primary juvenile), or recycled during the eruption (White and Houghton 2006). Juvenile clasts range from dense to vesicular, and include aggregates of finergrained clasts (e.g., accretionary lapilli). It can be difficult to distinguish new dense juvenile clasts from either earlier formed coherent rocks, such as dykes and plugs in the diatreme, that are fragmented during subsequent eruptions, or from country rock lithic clasts derived from pre-maar volcanic sources with similar compositions.

Pumice is a particular type of juvenile pyroclast, typically of felsic composition, with over $60 \%$ vesicles (Cashman et al. 2000). When workers have called clasts with less than $60 \%$ vesicles 'pumice', the single quotation marks are used to show that these clasts are not strictly pumice.

Quartz latite: one diatreme reviewed here is described as having been formed by quartz latite magma, and no geochemistry is available to position these rocks in the total alkali silica (TAS) diagram and compare them with other diatremes. Quartz latite is not specifically defined in the TAS diagram: instead, in the IUGS classification, this is "a volcanic rock in which $\mathrm{Q} /(\mathrm{Q}+\mathrm{A}+\mathrm{P})$ is between 5 and 20 , and $\mathrm{P} /(\mathrm{A}+\mathrm{P})$ is between 35 and $65 "$, where $\mathrm{Q}$ is quartz, $\mathrm{P}$ is plagioclase, $\mathrm{A}$ is alkali feldspar (American Geosciences Institute, Glossary of Geology, $5^{\text {th }}$ edition). To get an approximate idea of where quartz latites generally plot in the TAS diagram, we compiled the 138 whole-rock samples labelled as such in the GEOROC database, for which the elements $\mathrm{Si}, \mathrm{Na}$ and $\mathrm{K}$ were available. This shows that the vast majority of samples plot 
in the dacite and trachyte/trachydacite fields in the TAS diagram.

We now present felsic maar-diatreme volcanoes from top to bottom, focusing on the best documented examples (Table 1).

\section{Felsic maars and tuff rings}

Wau in Papua New Guinea is a Pliocene volcano in which the maar ejecta ring, the post-eruptive crater infill, and the underlying diatreme is known (Sillitoe et al. 1984). Since we know of no other examples of well documented true felsic maars ${ }^{1}$, we also review two Pleistocene Mexican felsic tuff rings: Hoya de Estrada (Cano-Cruz 2007; CanoCruz and Carrasco-Núñez 2008) and Tepexitl (Erickson 2007; Austin-Erickson et al. 2008, 2011). In mafic volcanoes, the ejecta rings around maars are very similar to those of tuff ring volcanoes, and we assume that the same applies to felsic maars. Therefore the two Mexican tuff rings provide information on what the ejecta rings of felsic maars potentially look like.

The craters of felsic maars and tuff rings can be large: 1.2 $\mathrm{km}$ at Hoya de Estrada, $1 \mathrm{~km}$ at Tepexitl, $1.4 \mathrm{~km}$ at Wau. The ejecta rings are up to $50 \mathrm{~m}+$ thick (Tepexitl) and extend laterally up to $1.8 \mathrm{~km}$ from the craters (Hoya de Estrada). The bedded pyroclastic deposits in the ejecta rings contain a mixture of lithic and juvenile clasts (all three examples). Some beds display cross-bedding attributed to surge deposition (all three examples), as well as accretionary lapilli (all three examples). Other beds are interpreted as pyroclastic fall deposits. There is no lava dome in or near the crater in the two Mexican examples, although a dome seems to have existed at some stage, and to have been subsequently destroyed, in both cases (see details below). At Wau, felsic domes occur outside of the crater and are interpreted as contemporaneous with the maar-diatreme volcano.

\section{Hoya de Estrada \\ Description}

Hoya de Estrada is a $0.18 \pm 0.03$ Ma rhyolitic tuff ring in the Valle de Santiago volcanic field, within the central part of the Trans-Mexican Volcanic Belt (Fig. 1a). The following summary is based largely on Cano-Cruz (2007) and Cano-Cruz and Carrasco-Núñez (2008) and the reader is referred to these sources for some additional details and methodological information, but new photos are included here, and a slightly updated interpretation of eruptive processes. The Valle de Santiago area lies in the intersection of two dominant structural trends (NNW and E-W), where more than ten maar volcanoes are aligned in the NNW direction. Most of the volcanoes in this field are basaltic to andesitic, except for Hoya de Estrada. The circular crater at Hoya de Estrada is $1.23 \mathrm{~km}$ in diameter

\footnotetext{
${ }^{1}$ Acıgöl maar in Turkey is reported to be rhyolitic (Gençalioğlu-
} Kuşcu et al. 2012), but unfortunately no details are available. and its current depth is $60 \mathrm{~m}$ relative to the rim (Fig. 1b); it currently does not contain a lake. Country rocks consist mainly of andesitic lavas but are not exposed in the crater walls.

The ejecta ring is known to extend up to $1.8 \mathrm{~km}$ from the crater rim. The proximal deposits are well exposed (Figs. 1c, 1d) and the composite stratigraphic section is $45 \mathrm{~m}$ thick (see Fig. 2a, which does not show the youngest unit, a mafic spatter deposit). The thickest section logged at one place is about $27 \mathrm{~m}$, on the eastern side (Fig. 1b). The tuff ring consists of two stratigraphic units, separated by an undulating contact (Figs. 1c, 2a). The lower unit is dominated by relatively indurated layers of coarse ash to fine lapilli, with minor non-indurated lapilli layers. The median clast diameter of the non-indurated layers, determined by dry sieving, is mostly 0 to -3 phi ( 1 to 8 $\mathrm{mm}$ ) (Fig. 2b). The upper unit is mostly not indurated, and coarser on average, with layers consisting mostly of medium to coarse lapilli. For unconsolidated layers, the median clast diameter is mostly within the -2 to -3 phi (4 to $8 \mathrm{~mm}$ ) range (Fig. 2b) in the upper unit. For both units, Inman sorting values for unconsolidated layers are relatively constant, typically ranging from 2 to 3 (Fig. 2c), which translates as poorly sorted in the Cas and Wright (1987) scheme (a few samples have sorting values of less than 2, corresponding to the well sorted category). According to a visual estimate, sorting is poorer in the indurated ash beds.

In general, juvenile clasts are subangular to subrounded, and lithic clasts are subangular to angular. Within the lapilli size fraction of the unconsolidated layers, the firstand second-most abundant lithic types are andesite and altered/oxidized clasts, respectively (Fig. 2d). Six types of juvenile clasts are found in the tuff ring: pale gray rhyolite, dark gray rhyolite, pale gray (rhyolitic) 'pumice', dark grey (dacitic) pumice, rhyolitic breccias (see Cano-Cruz and Carrasco-Núñez 2008 for details) and felsic clasts with mafic enclaves (Fig. 2d). The lower unit contains only pale gray rhyolite, dark gray rhyolite (both of which have about $5-15 \%$ vesicles), and pale gray (rhyolitic) 'pumice', whereas the upper unit contains all types. Pale gray 'pumice' has a restricted silica content (73-75 wt $\% \mathrm{SiO}_{2}$; no normalization) with an average vesicularity in the lower unit (38-41\%) that contrasts with the more variable vesicularity of clasts in the upper unit ( 30-55\%). Dark gray (dacitic) pumice has an average silica content of 63 71 wt. $\% \mathrm{SiO}_{2}$ and an average vesicularity of $\sim 65 \%$.

The 24.5-m thick lower unit, characterized by crossbedding, accretionary lapilli, bomb sags, channels, undulating beds (Fig. 1d) and lithic-rich deposits (up to $80 \%$; Fig. 2d), is divided into three members, A to C (Fig. 2a). Member A comprises a $7.6 \mathrm{~m}$-thick finely stratified 
and laminated sequence showing cross-stratification (Fig. 3a), abundant accretionary lapilli, and occasional bomb sags. Ash layers alternate with thin lapilli layers comprising pale gray 'pumice' and poorly vesicular rhyolite clasts. This is conformably overlaid by Member B, a $6.6 \mathrm{~m}$-thick bedded sequence dominated by massive to diffusely stratified, clast-supported, medium-to-fine lapilli layers with abundant lithic clasts and subordinated juvenile clasts. This alternates with some thin, indurated, laminated ash layers (Fig. 3b). A few oversized lithic blocks are up to $12 \mathrm{~cm}$ in diameter, whereas the juvenile clasts average 2 $\mathrm{cm}$ in diameter (max. $10 \mathrm{~cm}$ ). Member $\mathrm{C}$ is $10.3 \mathrm{~m}$-thick and includes a basal coarse ash, cross-bedded, indurated sequence featuring accretionary lapilli and frequent bomb sags associated with ballistic lithic blocks (Fig. 3c). This grades upwards into a stratified sequence consisting of thin clast-supported lithic-rich lapilli layers (Fig. 3d).

The 20.7-m thick upper unit, characterized by coarser and more massive deposits that contain lesser proportions of lithic clasts (mostly <50\%; Fig. 2d), is composed of three members, D to F (Fig. 3e). Member D is $11.2 \mathrm{~m}$ thick and mostly comprises clast-supported, plane-parallel layers of coarse to fine lapilli, some with lithic clasts as well as 'pumice' (including dark gray pumice) and rhyolitic clasts (Figs. 3e, 3f). These alternate with subordinate thin indurated ash layers, some of which are cross-bedded and undulating. Blocks in member $\mathrm{D}$ are about $15 \mathrm{~cm}$ in diameter, but some reach up to $25 \mathrm{~cm}$. Member E is $4.9 \mathrm{~m}$ thick and includes, at its base and top, two thick, massive, clast-supported layers made up of overwhelmingly juvenile coarse lapilli, with very minor amounts of lithic clasts (Figs. 2d, 3e). These thick layers include blocks ranging in size from 35 to $60 \mathrm{~cm}$ in diameter. The middle part of member E contains clast-supported layers of coarse lapilli of variable componentry. Member F is a $4.6 \mathrm{~m}$-thick stratified sequence containing indurated coarse ash layers alternating with non-indurated coarse lapilli layers (Fig. $3 e)$. The latter contains blocks up to $20 \mathrm{~cm}$ in diameter.

Within the western portion of the crater sits a small spatter accumulation, approximately $5 \mathrm{~m}$ thick, made of welded trachyandesite $\left(55-56 \% \mathrm{SiO}_{2}\right)$ clasts up to $60 \mathrm{~cm}$ in diameter.

\section{Interpretation}

Both the lower unit and the upper unit of the Hoya de

Estrada tuff ring are interpreted as products of

phreatomagmatic fragmentation, based on (i) the

abundance of lithic clasts (especially in the lower unit); (ii) the low vesicularity of many juvenile clasts; (iii) evidence for moisture in the eruption column and deposits, such as accretionary lapilli (especially in the lower unit), ballistic sags with plastic deformation of the underlying material (in the lower unit only) and indurated ash layers. The source of the groundwater is inferred to have been within fractures in the andesitic country rock. The felsic magma that was fragmented had both relatively dense and vesicular portions, as shown by the coexistence of several types of juvenile fragments in each sampled layer. Given the coarser average grain size, the efficiency of fragmentation may have been less in the upper unit. This is supported by the paucity of evidence for external water in the upper unit. However, other factors than the water-magma ratio can explain or contribute to the difference in grain size, such as the influence of pre-existing craters and the depth and intensity of individual explosions (Taddeucci et al. 2013; Graettinger et al. 2015; Valentine et al. 2015).

The lower unit consists mostly of the deposits of pyroclastic surges (Fig. 2e), as demonstrated by crossstratification and undulating beds. The abundance of water in the erupting mixture contributed to a surge-dominated regime. The less abundant lapilli layers of the lower unit are clast-supported, better sorted, display mantle bedding, and thus are interpreted as fallout. The undulating contact between the two main units may indicate a brief period of repose although the time gap between the lower and upper units, if any, was not sufficient for paleosol development.

The upper unit consists mostly of pyroclastic fall deposits with some surge beds (Fig. 2e). The fallout layers are characterized by their lateral continuity, a clast-supported framework, comparatively good sorting (compared with the finer grained surge layers) and an absence of bomb sags. Cano-Cruz and Carrasco-Núñez (2008) propose that a dome or cryptodome of rhyolite was constructed in the crater, and then destroyed (Fig. 2e), as shown by the abundance of rhyolite blocks, especially in member E (Fig. $2 d)$.

After the construction of the rhyolitic tuff ring was complete, a small mafic lava fountain occurred and formed welded basaltic trachyandesite spatter on the western portion of the crater (not shown on Fig. 2). Mafic and felsic magmas were both present during formation of the upper unit of the tuff ring (Fig. 2e), based on the presence of mafic enclaves in some felsic juvenile clasts (Fig. 2d), and mafic and felsic banding in some of the pumiceous clasts. The presence of dark gray (dacitic) pumice clasts within the upper unit is consistent with complete, but local, mixing between the mafic and silicic end-member compositions and the more vesicular nature of the dacitic pumice clasts, in comparison to rhyolitic pumice, can be explained by a gas-rich mafic magma.

\section{Tepexitl}

\section{Description}

Tepexitl is a rhyolitic tuff ring located in the center of the Serdán-Oriental Basin within the eastern Trans-Mexican Volcanic Belt (Fig. 4a). Tepexitl occurs along a NW-SE fault, along with two rhyolitic dome ( \pm tuff ring) complexes (Las Derrumbadas and Cerro Pinto). Most of the volcanoes in the Serdán-Oriental Basin are mafic (scoria cones and maars, e.g., Carrasco-Núñez et al. 2007; Ort and CarrascoNúñez 2009). The following information is taken from 
Erickson (2007) and Austin-Erickson et al. (2008, 2011), except for a new Ar-Ar date presented at the end of this section. The reader is referred to these sources for additional details and methodological information about Tepexitl.

The Tepexitl crater is approximately circular and $1 \mathrm{~km}$ in diameter from rim to rim (Fig. 4b, dashed line). The current lake-free crater floor is $20 \mathrm{~m}$ lower than the surrounding terrain, and the pyroclastic deposits contain an average of $27 \%$ lithics, indicating significant excavation into the country rocks. However, the country rocks are not exposed in the crater walls at Tepexitl, whereas this is the case for basaltic maars in the area, which also contain lakes. The estimated volume of the Tepexitl ejecta ring is $0.036 \mathrm{~km}^{3}$. Juvenile clasts contain $\sim 75 \% \mathrm{SiO}_{2}$ volatile-free and display $3-7 \%$ phenocrysts $(0.05-0.4 \mathrm{~mm}$, mostly quartz and plagioclase).

Pyroclastic deposits from the proximal ejecta ring are divided into a lower sequence and an upper sequence, both made up of outward dipping beds (Fig. 4c), which are well exposed on the east and south sides of the crater. The composite stratigraphic section through the ejecta ring is $55 \mathrm{~m}$-thick (Fig. 4d), of which $50 \mathrm{~m}$ can be measured in a single site (section CS on Fig. 4b). This accounts for units $\mathrm{L} 1$ to L5 and U1 to U2 on Fig. 4d. The last $5 \mathrm{~m}$ (unit U3) of the composite section was measured on the NW crater rim (Fig. 4b). An outcrop of distal deposits occurs $1.5 \mathrm{~km}$ from the crater (not shown). Six volcanic facies are observed in the crater wall deposits: three fine ash facies (median diameter 2.5 to 1.6 phi or about $0.18 \mathrm{~mm}$ to $0.33 \mathrm{~mm}$ ) and three coarse ash to fine lapilli facies (median diameter -0.4 to -2.6 phi or about $1.3 \mathrm{~mm}$ to $6.1 \mathrm{~mm}$ ), which alternate every 10 to $100 \mathrm{~cm}$ vertically. Inman sorting is poor to very poor for all facies, as determined by dry sieving.

In the thinly bedded lower sequence (L1-L4), fine-grained facies dominate, there is an abundance of tuff with softsediment deformation, and block-size clasts are rare, mostly in the $1-7 \%$ range (with blocks consisting mostly of juvenile obsidian and of lithic fragments). Accretionary lapilli, scour channels, undulatory bedding, dune bedforms and bomb/lapilli sags are observed. Lithic contents range from $11 \%$ to $54 \%$ in the 2 phi $(0.25 \mathrm{~mm})$ size fraction (Fig. 4d) and juvenile clasts make up the rest of this size fraction. Juvenile clasts, listed from most to least abundant, include: stony rhyolite, obsidian (Fig. 4d) and rare pumice (not shown on Fig. 4d). The juvenile clasts are mostly of low vesicularity $(0-25 \%)$. Juvenile ash in the 4 phi $(0.063 \mathrm{~mm})$ size fraction is dominated by dense blocky particles with features such as stepped fractures, branching quench cracks, and pitting.

In the upper sequence (U1-U3), the beds are coarsergrained, lack bomb sags, and contain abundant blocks (20$30 \%$ ) dominated by stony rhyolite. Soft-sediment deformation features are rare to absent. The proportion of lithic clasts ranges from $0 \%$ to $34 \%$ in the 2 phi $(0.25 \mathrm{~mm})$ size fraction but is mostly below $20 \%$ (Fig. 4d). The same types of juvenile clasts in similar relative proportions are observed in upper unit as found in the lower unit.

Volatile content was measured from loss on ignition data obtained by heating juvenile clasts from $200^{\circ} \mathrm{C}$ to $1000^{\circ} \mathrm{C}$. Obsidian clasts contain about $1 \%$ volatiles (mostly magmatic $\mathrm{H}_{2} \mathrm{O}$ ) whereas stony rhyolite clasts contain $\sim 2 \%$ volatiles.

\section{Interpretation}

The lower sequence is interpreted by Erickson (2007) and Austin-Erickson et al. $(2008,2011)$ as phreatomagmatic in origin, based on the fine-grained nature of proximal deposits, the relatively high abundance of lithic clasts, the presence of bomb sags and scour channels, the nature of the juvenile clasts $(0-25 \%$ vesicles, with particle shapes and surface features typical of phreatomagmatic fragmentation), and the presence of accretionary lapilli. More specifically, phreatomagmatic blasts associated with abundant external water are invoked, especially for units L1 to L3, where the lithic contents are the highest. The source of this water was a shallow, sandy-silty aquifer. Excavation (diatreme development) seems to have stopped during formation of units L4 and L5, and it is possible that dome growth started at this stage, but the dome was repeatedly destroyed. Pyroclastic surges were the dominant depositional mechanism, as shown by undulatory bedding, duneforms, and scour channels. Obsidian clasts are interpreted as derived from the margin of a felsic plug/conduit, whereas the stony rhyolite clasts are thought to represent the interior of a plug/conduit or dome.

During formation of the upper sequence, external water had less of an influence on the eruptive style, as shown by the lack of bomb/lapilli sags, lack of deformed tuff, coarser grainsize, and lower abundance of lithic fragments. In detail, units U1 and U2 are interpreted by Erickson (2007) and Austin-Erickson et al. $(2008,2011)$ as formed by relatively dry or low energy phreatomagmatic activity, or magmatic explosive activity, with the magma plug present at a shallow depth or even above the crater floor, as a dome. Unit U3 was formed by the destruction of a small lava dome (about 2 million cubic meters) or plug, with the possible causes of explosions including internal pressure build-up, and external water such as rainwater and groundwater. These explosions widened the crater westward.

The LOI data, along with the generally dense to low vesicular nature of the juvenile clasts, indicates that magma degassing and outgassing were not complete at the time of fragmentation and quenching. Obsidian clasts were formed in an area of the plug/conduit where more outgassing was taking place, relative to stony rhyolite clasts. 
New Ar-Ar date

We have obtained a new date for the Tepexitl tuff ring. The sample was collected by G.C.N. from a large mostly aphanitic rhyolite juvenile clast containing abundant plagioclase and minor amounts of biotite crystals within a microlitic matrix. ${ }^{40} \mathrm{Ar} /{ }^{39} \mathrm{Ar}$ dating was done in the Department of Geoscience at the University of Wisconsin, on the groundmass of the sample. The irradiated sample was step-heated with a laser. A plateau age of $29.1 \pm 3.5 \mathrm{ka}$ was obtained, taking into account a two sigma error (Supplementary Figure S1). This is interpreted as the crystallization age of the juvenile rhyolite clast and therefore as the age of the eruption.

\section{Wau}

Wau is a $\sim 2.4$ Ma degraded maar-diatreme-dome complex in the Morobe goldfield of Papua New Guinea (Fig. 5) and was studied by Sillitoe et al. (1984) because it hosts epithermal gold mineralization. The following account, including the quotes, is based on that paper, unless otherwise noted. Pre-maar rocks include Late Cretaceous to Paleogene basement rocks (Kaindi Metamorphics), as well as Pliocene ignimbrites (Bulolo Ignimbrite, about 1 m.y. older than the maar) and fluviatile sediments (Otibanda Formation) (Fig. 5). The pre-maar Pliocene deposits are now tilted due to fault activity. The Wau maar crater is situated 600-1000 m east of a major fault zone, dipping about 40 degrees eastward. The volcanic structure is about $1.4 \mathrm{~km}$ across, at the present erosion level, and $<100 \mathrm{~m}$ of deposits are estimated to be missing since the ejecta ring is partly preserved and the crater is occupied in part by lacustrine mudstones, travertine and sinter.

The ejecta ring deposits are locally known as the Namie Breccia and crop out to the west and south up to $1.6 \mathrm{~km}$ from of the crater. The Namie Breccia is "composed of angular to rounded fragments of Kaindi Metamorphics and dacite porphyry set in a gray-colored matrix of finely comminuted rock material". The dacite porphyry clasts include pumiceous fragments which may be juvenile or derived from the Bulolo Ignimbrite. The dacite porphyry clasts also include flow-banded clasts interpreted by Sillitoe et al. (1984) as possibly derived from a pre-maar dome, although based on other felsic maar-diatremes (e.g., Tepexitl), the flow-banded clasts could also be derived from the margins of a plug or dike (this study). Most beds in the Namie Breccia are coarse, poorly stratified and poorly sorted. These are interbedded with a "fine, silty, and well-stratified facies", which is thinly bedded, with lowangle stratification and accretionary lapilli; this latter facies is interpreted by Sillitoe et al. (1984) as deposited by pyroclastic surges. Smaller occurrences of Namie Breccia within the maar crater are "interpreted as blocks that slid into the maar at a later date" (Fig. 6a), although one deep occurrence is interpreted as a subsided block within the diatreme.
The deposits infilling the post-eruptive crater and the upper diatreme are intersected in drill holes to depths of about $300 \mathrm{~m}$ (Fig. 5). The diatreme is probably much deeper, based on the crater diameter (see Lorenz 1986) and the angle of the ring fault, which dips at 50-70 degrees inward (Fig. 6a). The deposits within the post-eruptive crater and upper diatreme are bedded, with dip angles $>30$ degrees (Fig. 5). They consist of an upper sedimentary and reworked pyroclastic sequence within the post-eruptive crater, and a lower pyroclastic sequence within the diatreme. The upper sequence includes grits, sandstones, and laminated mudstones including "horizons rich in plant matter as well as cherty horizons with bedded pyrite", plus local travertine and sinter. The lower sequence contains abundant dacite porphyry clasts and fewer Kaindi Metamorphics clasts than in the Namie Breccia, contained in a pale matrix. Well-bedded horizons and accretionary lapilli are known. These upper diatreme pyroclastic deposits are interpreted by Sillitoe et al. (1984) as phreatomagmatic fall and surge deposits.

Two main lava domes, considered contemporaneous to maar formation, occur next to the maar (Fig. 5) with locations partly controlled by the diatreme walls (Fig. 6a). The NW dome is composed of dacite porphyry whereas the southern one is made of andesite porphyry (no geochemical analyses supplied). The flanks of the NW dome are made of coarse monomictic breccia with dense dacite blocks up to $2 \mathrm{~m}$ across or more; the finer-grained version of this breccia is intercalated with the post-eruptive crater infill.

Hydrothermal brecciation, hydrothermal alteration and gold mineralization at Wau are generally thought to have occurred during dome emplacement and maar-diatreme formation. In detail, gold may have been deposited after the initial maar-diatreme activity but before emplacement of the last lava dome. Post-maar events include Pleistocene(?) fluviatile sedimentation and landslides. The Koranga Crater, which cuts the SE portion of the Wau maar (Fig. 5), may have been formed during hydrothermal eruptions in 1967 and before.

In contrast to the interpretation of Sillitoe et al. (1984), Corbett and Leach (1998) suggest that the Namie Breccia at Upper Ridges was created by an earlier (pre-Wau) phreatomagmatic event (Fig. 6b). Corbett and Leach (1998) mention two more diatremes in the same district, Nauti and Kerimenge, but Sillitoe (pers. commun., 2016) thinks that "these rocks are almost certainly fluvial sediments unrelated to diatremes".

\section{Felsic diatremes}

Apart from Wau, described in the previous section, the four main examples of felsic diatremes reviewed here are Montana Tunnels, Montana (Sillitoe et al. 1985); Cerro de Pasco, Peru (Silberman and Noble 1977; Rogers 1983; Baumgartner et al. 2008, 2009); Kelian, Indonesia (Davies 
2002; Davies et al. 2008a, 2008b); and Mt Rawdon, Australia (Brooker 1991; Brooker and Jaireth 1995; this study). These were chosen due to the relative completeness of information about them, and lack of strong debate about their origin (as opposed to some other sites). Some incomplete diatreme characterizations are available for Cripple Creek, Colorado (Thompson et al. 1985), El Teniente, Chile (Howell and Molloy 1960), Guinaoang, Philippines (Sillitoe and Angeles 1985), and Roşia Montană, Romania (Hewson et al. 2005; Manske et al. 2006; Wallier et al. 2006; Tămaş and Minuţ 2012). Other examples were compiled by Sillitoe and Bonham (1984) and Sillitoe (1985) such as Acupan (Philippines), Bassick (Colorado), or Dizon (Philippines), but no modern descriptions of these diatremes seem available. Rhyolitic diatremes are mentioned by Lorenz and Haneke (2004) in the Saar-Nahe basin of Germany but unfortunately few details are given. Based on these examples, the following characteristics can be extracted for felsic diatremes:

- The diatremes can have steep walls (e.g., western part of Cripple Creek; Kelian; Montana Tunnels) that may locally overhang.

- The diatreme contacts can be defined by ring faults (Cerro de Pasco; Runcing Breccia at Kelian; Wau) or linear faults (Mt Rawdon).

- The diatremes can be large in horizontal dimensions (Montana Tunnels $=2.1 \mathrm{~km} \mathrm{~N}-\mathrm{S}$, surface area about $1 \mathrm{~km}^{2}$; Guinaoang 8.5 x $3.5 \mathrm{~km}$; Cerro de Pasco 2.0-2.5 km diameter), but those of the Saar-Nahe basin are only "several tens to hundreds of meters in diameter"; the largest ones may represent coalescence of several diatremes.

- Some diatremes have a large vertical extent: the Braden pipe at El Teniente is over $1.6 \mathrm{~km}$ deep, and most diatremes compiled by Sillitoe (1985) are over $300 \mathrm{~m}$ deep.

- The diatremes are largely filled by pyroclastic rocks; other rock types are megablocks of country rocks or of bedded pyroclastic rocks, and felsic dikes and plugs (details below).

- Pyroclastic rocks in diatremes are typically poorly sorted, and ash-rich. They contain a heterolithologic mix of juvenile clasts and lithic clasts from various depths (Cerro de Pasco; some volcaniclastic facies at Kelian; Montana Tunnels; Mt Rawdon).

- Most juvenile clasts in diatremes have no vesicles or have a low vesicularity (e.g., Mt Rawdon), although some lithofacies at Cerro de Pasco and Guinaoang contain pumice or welded pumice ${ }^{2}$.
- In the upper part of diatremes, pyroclastic rocks can be bedded (Braden Pipe at El Teniente; Mt Rawdon; Wau).

- The lower parts of diatremes are typically not bedded (Kelian, Montana Tunnels).

- Cross-cutting bodies of finer or coarser-grained pyroclastic material (Montana Tunnels), or different composition (Kelian, possibly Mt Rawdon), are sometimes observed in the diatreme infill.

- The diatremes can contain country rock megablocks up to hundreds of meters long (Cerro de Pasco; Montana Tunnels). They can also contain megablocks of bedded ejecta ring (or upper diatreme) material with cross-bedding (Cerro de Pasco, Cripple Creek, Dizon, Guinaoang, Kelian, Montana Tunnels), and accretionary lapilli (Cripple Creek, Cerro de Pasco, Dizon, Guinaoang, Kelian). A final type of megablock consists of fluvio-lacustrine sediments inferred to have been deposited in the maar (Cripple Creek).

- Inclusions of carbonized wood are sometimes found (Acupan, Bassick, Cripple Creek, Dizon, Kelian, Montana Tunnels, Roşia Montană).

- The pyroclastic rocks are often cut by coherent dikes or plugs of the same composition as the juvenile clasts within the pyroclastic rocks (many examples). Intrusions can be pre-, syn- or postdiatreme.

- It is sometimes possible to observe country rock breccias between intact country rocks and the heterolithologic diatreme infill (Kelian, Mt Rawdon) or within the diatreme (Montana Tunnels).

- There is sometimes an association with peperites or peperite-like rocks (Kelian, Montana Tunnels, Mt Rawdon).

The minimum preserved volumes of the felsic diatremes reviewed below range from $\sim 0.2 \mathrm{~km}^{3}$ for the Tepu Breccia at Kelian to $\sim 3.6 \mathrm{~km}^{3}$ at Cerro de Pasco, using truncated cone shapes, the reported diatreme diameters at the premining surface, known minimum depths, and assuming $70^{\circ}$ walls for simplicity (Table 1 ). These are obviously underestimates of the original volumes, due to posteruptive erosion, and drilling often not reaching maximum depths. It is assumed that all felsic diatremes described in this section originally had maars on top of them, even though the ejecta rings and the post-eruptive crater-filling sediments are now eroded.

\footnotetext{
${ }^{2}$ In general, it should be noted that the fiamme or eutaxitic texture in pumiceous deposits is not always due to welding (Gifkins et al. 2005; Bull and McPhie 2007).
} 


\section{Montana Tunnels}

Montana Tunnels is a diatreme-hosted Au-Ag-Pb-Zn (epithermal) ore deposit in SW Montana, USA (Fig. 7). Production started from an open pit in 1986 (Schaefer 2012). Some 23 years later, $98 \mathrm{Mt}$ of ore had been processed with extracted grades of $\sim 0.51 \mathrm{~g} / \mathrm{t} \mathrm{Au}$, $\sim 9.5 \mathrm{~g} / \mathrm{t} \mathrm{Ag}, \sim 0.18 \% \mathrm{~Pb}$ and $\sim 0.51 \% \mathrm{Zn}$ (calculated from production figures in Schaefer 2012: $1.6 \mathrm{Moz}$ gold, 30 Moz Ag, 400 million lb $\mathrm{Pb}, 1.1$ billion $\mathrm{lb} \mathrm{Zn}$ ). There are plans for more production in the future. The following information, including quoted text, is taken from Sillitoe et al. (1985).

The Montana Tunnels diatreme is Eocene $(50 \pm 2 \mathrm{Ma})$; two more diatremes of the same age are known in the district in association with a quartz latite porphyry dike swarm. Prediatreme rocks include the Late Cretaceous Elkhorn Mountains Volcanics (middle unit: altered felsic ignimbrites; upper unit: andesitic fluvial sediments), dipping 20-30 towards the SE; Late Cretaceous intrusions including the Butte Quartz Monzonite; and the Eocene Lowland Creek Volcanics (mostly welded crystal-rich ignimbrites, some lithic-rich ignimbrites), dipping $15-35^{\circ}$ to the ESE (Fig. 7). The latter ignimbrites have approximately the same radiometric age as the diatremes and quartz latite porphyry dikes, suggesting a "temporal and genetic relationship", although the Montana Tunnels diatreme cuts the Lowland Creek Volcanics so it must be slightly younger.

The diatreme is elongated N-S, with a maximum horizontal size of $2.1 \mathrm{~km}$ at the current erosion level, estimated to be "at least several hundred meters" below the pre-eruptive surface. The diatreme is known by drilling to depths of at least $310 \mathrm{~m}$ from the pre-mining surface, and its walls are nearly vertical. The dominant diatreme infill, known as the 'heterolithologic diatreme breccia', is a non-bedded, gray to white "wackelike" rock, with 70-90\% matrix less than 2 $\mathrm{mm}$ in grain size. The matrix has over $80 \%$ sand-grade material in it, as opposed to clay- and silt-grade; it contains crystals and crystal fragments (quartz, feldspar, biotite, and feldspar) interpreted as juvenile, as well as crystal aggregates and lithic particles. Most fragments larger than $2 \mathrm{~mm}$ are less than $3 \mathrm{~cm}$ across (locally $20 \mathrm{~cm}$ ); these fragments are sub-angular to well rounded. They consist of Elkhorn Mountains Volcanics, quartz monzonite, alaskite (leucogranite), aplite, quartz latite porphyry, and Lowland Creek ignimbrite. The quartz latite porphyry clasts are interpreted as juvenile and all the other clast types are lithic. The quartz monzonite, alaskite and aplite clasts are thought to have been sourced from host rocks lower in the sequence, whereas carbonized wood and megablocks of ejecta ring deposits (see below) have travelled down from the paleosurface.

Cross-cutting bodies of 'diatreme breccia' occur, and are distinguished from the main 'heterolithologic diatreme breccia' based on grain size and matrix proportions: some cross-cutting bodies contain "as little as 10\% matrix" and consist mostly of fragments $0.5-3 \mathrm{~cm}$ across, whereas other bodies consist largely of matrix without larger clasts.

The diatreme contains megablocks and domains of the upper unit of the Elkhorn Mountains Volcanics and of Lowland Creek ignimbrite. In particular, half of the northern part of the diatreme is occupied by a large mass of lithic-rich ignimbrite from the Lowland Creek Volcanics (Fig. 7). The domains of Elkhorn Mountains Volcanics (black triangles on the map) are $<270 \mathrm{~m}$ long, are brecciated (i.e., they form country rock breccias) and are locally injected by "veins" of 'diatreme breccia' 0.1->15 m wide.

Smaller blocks floating in the 'diatreme breccia' are interpreted as ejecta ring remnants that have subsided in the diatreme (not shown on the map). They consist of bedded sand-grade material similar in composition to the matrix of the diatreme infill, but the grains are more angular and smaller $(<1 \mathrm{~mm})$. Cross-bedding and dune forms have been observed in this material, suggesting original deposition from phreatomagmatic surges.

At least three quartz latite porphyry dikes cut the 'diatreme breccia' as well as the included megablocks and country rock breccias. The largest dikes are up to $90 \mathrm{~m}$ wide and do not extend into the diatreme host rocks, although other quartz latite porphyry dikes are found in the host rocks. The contact relationships between the 'diatreme breccias' and the dikes are described as complex: "in some places, irregular veinlets of [diatreme] breccia were injected into the walls of dikes, whereas elsewhere swirly tongues of quartz latite porphyry were intruded into the breccia" and locally, "globular masses of porphyry were detached from these offshoots and incorporated as clasts in the breccia and, in common with the margins of dikes and their offshoots developed dark gray chilled zones against the breccia". These thick dikes may have fed extrusive domes, now eroded.

\section{Cerro de Pasco}

Cerro de Pasco is a Cordilleran base metal ( $\mathrm{Zn}-\mathrm{Pb}-\mathrm{Ag}-\mathrm{Cu}-$ Bi) deposit in central Peru, associated with a mid-Miocene diatreme-dome complex (Baumgartner et al. 2008) and has been mined since at least 1630 . Known resources and post1950 production total more than $175 \mathrm{Mt}$ grading $7 \% \mathrm{Zn}$, $2 \% \mathrm{~Pb}$, and $3 \mathrm{oz} / \mathrm{t} \mathrm{Ag}$ (Baumgartner et al. 2008). Other diatreme-dome complexes occur south of Cerro de Pasco at Colquijirca and Yanamate (Baumgartner et al. 2009). The Cerro de Pasco volcanic structure was interpreted as a small caldera by Rogers (1983) but as a felsic diatreme by Silberman and Noble (1977), Sillitoe (1985) and Baumgartner et al. $(2008,2009)$. The diatreme interpretation is retained here due to similarity with other felsic diatremes, lack of reported pumice in the dominant vent fill, and small size relative to many calderas.

However, Cerro de Pasco is the largest diatreme reviewed 
here in detail and is the only one showing clear evidence of a magmatic explosive style for a significant portion of its eruptive history (see below), suggesting that it may indeed be a 'hydrid' between a maar-diatreme and a caldera, of the type proposed by Palladino et al. (2015).

The Cerro de Pasco diatreme occurs along a N-S regional high-angle reverse fault that juxtaposes rocks of different ages (Silberman and Noble 1977; Baumgartner et al. 2008). Country rocks adjacent to the diatreme include the Devonian Excelsior Group (shale, phyllite, quartzite), the Permo-Triassic Mitu Group (sandstone, conglomerate), and the Upper Triassic-Lower Jurassic Pucará Group (limestone, dolomite) (Baumgartner et al. 2008) (Fig. 8). The Eocene Shuco conglomerate is not exposed near the diatreme but is found as megablocks within it (Rogers 1983) (Fig. 8, cross-section B-B').

At surface, the diatreme is a roughly circular feature about $2 \mathrm{~km}$ (Rogers 1983) to $2.5 \mathrm{~km}$ (Baumgartner et al. 2009) in diameter, with very steep contacts (Rogers 1983). Postdiatreme erosion is estimated to be about $500 \mathrm{~m}$ (Baumgartner et al. 2008). The structure contains two types of felsic volcaniclastic rocks (see below), dacitic to rhyodacitic "domes" (see below) as well as dikes and masses of quartz monzonite porphyry (Rogers 1983; Baumgartner et al. 2009). The dacites and quartz monzonites contain $61-67 \% \mathrm{SiO}_{2}$ before normalization to volatile-free compositions. After normalization, they plot in the dacite field on the TAS diagram (Baumgartner 2007).

Dating of single zircon crystals by U-Pb techniques produced ages of "15.36 $\pm 0.03 \mathrm{Ma}$ for an accretionary lapilli tuff from a collapsed block within the diatreme, $15.40 \pm 0.07 \mathrm{Ma}$ for a dacite porphyry dome in the diatreme, $15.35 \pm 0.05 \mathrm{Ma}$ and $15.16 \pm 0.04 \mathrm{Ma}$ for two quartz monzonite porphyry dikes" (Baumgartner et al. 2009).

The contact between the diatreme infill and the country rocks is a fault, which is expressed either as "a single polished surface", or "a zone, up to one meter wide, of closely spaced shear surfaces", or as "heterogeneous breccias containing fragments of rock from both within and outside the vent" (Rogers 1983).

The vertical extent of known diatreme infill is at least $1 \mathrm{~km}$ (Rogers 1983). Two types of volcaniclastic rocks are described by Rogers (1983) from the diatreme infill: (1) the Rumiallana Agglomerate; and (2) crystal-rich volcaniclastic rocks (intermediate to felsic tuffs on Fig. 8). The Rumiallana Agglomerate occupies most of the diatreme and consists of lithic-rich, heterolithic, matrixsupported, non-bedded to bedded volcaniclastic rocks (Silberman and Noble 1977; Rogers 1983; Baumgartner et al. 2009). The clasts in the Rumiallana Agglomerate are up to $24 \mathrm{~cm}$ long and are sub-angular to sub-rounded (Rogers
1983). Ninety percent or more of the clasts are lithic fragments (phyllite, limestone, and chert; Rogers 1983), derived from the Excelsior, Mitu, and Pucará groups (Baumgartner et al. 2009). Five to ten percent of fragments consist of "highly altered porphyritic igneous rock" (Rogers 1983), which may represent juvenile constituents. The componentry of these clasts varies laterally. The matrix (size cutoff not specified) contains plagioclase and biotite crystals which may also represent juvenile components; the matrix is described as "silicic" and "pyroclastic" by Silberman and Noble (1977). Rogers (1983) describes local thin bedding in the Rumiallana Agglomerate; Silberman and Noble (1977) mention crossbedding, dune structures, and "other features typical of base or ground surge deposits". The areas displaying thin bedding are interpreted by Baumgartner et al. (2009) as belonging to subsided megablocks derived from the noweroded ejecta ring, although it is not clear if the megablocks were observed within the Rumiallana Agglomerate or within the crystal-rich volcaniclastic rocks.

The northwest and south portions of the diatreme are occupied by different volcaniclastic rocks (Rogers 1983), of unspecified grain size but possibly finer than the Rumiallana Agglomerate. These are intermediate to felsic, white to gray, and commonly exhibit thin bedding (Rogers 1983). The rocks are crystal-rich (50-80\%: mostly quartz, feldspar, and biotite), and are reported to contain undeformed glass shards. Rare beds have a "eutaxitic texture", although pumice is not described in the beds which contain undeformed glass shards. Rogers (1983) interprets these rocks as mostly pyroclastic fall deposits and minor pyroclastic density current deposits. The contact between the Rumiallana Agglomerate and the crystal-rich volcaniclastic rocks is gradational (Rogers 1983; Fig. 8, cross-section A-A').

Bedding planes measured at surface in both volcaniclastic units show broadly centroclinal dips (Rogers 1983; Fig. 8, cross-section A-A'), suggesting subsidence. In detail, the strikes and dips are variable within relatively small areas, and "the scatter in the data suggests that the units were broken into blocks that moved semi-independently during the collapse" (Rogers 1983).

Megablocks within the diatreme infill are of two types. In the NW part of the complex, at unspecified locations, megablocks display dacitic tuff with cross-bedding, containing rim-type accretionary lapilli $2-5 \mathrm{~mm}$ in diameter. These megablocks are interpreted as derived from the ejecta ring (Baumgartner et al. 2009). In addition, country rock megablocks (Shuco Conglomerate, Pucara Group, Mitu Group) up to $\sim 700 \mathrm{~m}$ long, occur in the western part of the diatreme, along the ring fault.

Coherent dacite to rhyodacite porphyries occupy most of the SW part of the complex and intrude the volcaniclastic rocks. The porphyries display flow foliation with typically 
very steep angles (Fig. 8, cross-section B-B'). Rogers (1983) interprets the porphyries as the lower part of a series of interfingered mushroom-shaped features ("domes") that are each 100-500 $\mathrm{m}$ in diameter. The rocks contain variable proportions of quartz, feldspar, biotite, \pm thornblende phenocrysts within an aphanitic groundmass, and include devitrification textures in places. Coherent rocks are accompanied by local autobreccias (Rogers 1983).

The Rumiallana Agglomerate, which is the dominant vent fill, seem typical of felsic diatremes and could be phreatomagmatic given the very large proportion of country rock clasts. However, the locally welded crystalrich volcaniclastic rocks with glass shards are unusual for diatremes and may indicate a more magmatic explosive style in the western part of the structure. The relative chronology of emplacement between these two volcaniclastic rocks is not clear.

\section{Kelian}

The Kelian epithermal deposit of Kalimantan in Borneo, Indonesia, originally contained over $240 \mathrm{t} \mathrm{Au}(\sim 7.7 \mathrm{Moz})$, within resources of $92.1 \mathrm{Mt}$ grading $2.6 \mathrm{~g} / \mathrm{t} \mathrm{Au}$ (Davies et al. 2008a). It was mined in an open pit between 1991 and 2003. Maar-diatreme volcanism, with associated rhyolitic (QFP and QP) intrusions, occurred in the early Miocene, at about 19.8-19.5 Ma (Davies 2002). Country rocks adjacent to the diatremes include Upper Cretaceous felsic volcaniclastic rocks (Kelian Volcanics); Eocene to Oligocene sedimentary rocks including several carbonaceous lithologies; and Miocene andesitic (dioritic to plagioclase-hornblende porphyry) intrusions (Davies et al. 2008a, 2008b) (Fig. 9). The andesitic intrusions, diatremes and associated rhyolitic intrusions occur at the intersection of two regional-scale structures (Davies et al. 2008b).

The geology at Kelian is complex and fragmental rocks have various inferred origins including tectonic, hydrothermal, phreatic and phreatomagmatic (Davies et al. 2008b). The following account is condensed from Davies (2002) and Davies et al. (2008b) and focusses on rocks interpreted by these authors and Sillitoe (1994) to belong to three diatremes, referred to as, from north to south, the Runcing, Burung and Tepu Breccias (Fig. 9). All three diatremes narrow with depth and are mostly filled by nonbedded, matrix-rich, polymictic, juvenile clast-bearing pyroclastic rocks, with some diatreme margins occupied by country rock breccias (Fig. 10a). These country rock breccias are interpreted as both formed from collapse along the diatreme margins, and tectonic activity. Fragments of the ejecta ring are preserved within the diatremes (Fig. 10b).

The Runcing Breccia is $750 \mathrm{~m}$ by $750 \mathrm{~m}$ in horizontal dimensions with a roughly circular shape, and is over 500 $\mathrm{m}$ deep. It is surrounded by arcuate faults interpreted as ring faults. A 300x250x>75 m megablock of bedded pyroclastic rocks occurs in the middle part of the diatreme (Fig. 9, B facies). Rocks of the megablock are planarbedded to cross-bedded (e.g., Fig. 10c), with local dunes. They contain accretionary lapilli (Fig. 10d) and show soft sediment deformation. The southern portion of the diatreme, dominated by country rock breccias, is intruded by a QFP plug $550 \mathrm{~m}$ by $300 \mathrm{~m}$ across. The dominant pyroclastic infill is the non-bedded A4 facies (see below), which occurs in multiple pipes within the diatreme.

The Burung Breccia is $275 \times 175 \mathrm{~m}$ in horizontal dimensions, and over $450 \mathrm{~m}$ deep. On the west side there are country rock breccias and in the rest of the body, the A4 facies dominates. A small QFP rhyolite plug intrudes the body.

The Tepu Breccia is $750 \mathrm{~m}$ across and $>500 \mathrm{~m}$ deep. This diatreme contains steep pipes, tens of meters to less than $100 \mathrm{~m}$ across, extending hundreds of meters vertically, of pyroclastic rocks with contrasting characteristics, classified by Davies et al. (2008b) into different facies. Megablocks of bedded pyroclastic rocks occur. The dominant diatreme infill is the A3 and A4 facies.

The A4 facies is the most common non-bedded heterolithic diatreme infill for Kelian as a whole (Figs. 10b, 10e, 10f). These poorly sorted pyroclastic rocks are interpreted to be phreatomagmatic in origin. Fragments reach $50 \mathrm{~m}$ in size but are mostly $0.5-10 \mathrm{~cm}$ across; they are sub-angular to sub-rounded (Davies 2002). Lithic clasts most commonly consist of carbonaceous mudstone and fine sandstone, and also include coherent andesitic clasts (from pre-diatreme Miocene intrusions). Juvenile fragments, forming typically $5-30 \%$ of the clast population, consist of QP and/or QFP rhyolites. The finer than $2 \mathrm{~mm}$ matrix, representing 20$90 \%$ of the rock (typically 40-60\%), consists of lithic clasts (mostly carbonaceous mudstone and sandstone) and crystal fragments (quartz, feldspar). The largest A4 bodies reach over $500 \mathrm{~m}$ in vertical extent. Rare accretionary lapilli have been found in facies A4 (Davies 2002), and may have disaggregated from subsiding bedded pyroclastic megablocks derived from the ejecta ring (this study), since some beds in these megablocks contain up to $60 \%$ accretionary lapilli (Davies 2002). A less likely alternative is that the accretionary lapilli somehow formed underground in the diatreme (e.g., Woolsey et al. 1975), rather than in an eruption cloud or in a pyroclastic density current.

The A3 facies is less abundant but very interesting (Figs. $10 \mathrm{~g}, 10 \mathrm{~h}$ ). The rocks are described as texturally similar to blocky and fluidal peperites, although some interactions between intruding rhyolite magma and wet 'sediment' could have been explosive (phreatomagmatic). Among the clasts, there are 30-60\% carbonaceous sediments (lithic) and $10-80 \%$ QP and/or QFP rhyolite (juvenile). The latter clasts are $2 \mathrm{~mm}$ to $18 \mathrm{~cm}$ in size, and come in two main 
varieties. The first is "ragged and wispy with fine feathery margins" and the second is "blocky with curviplanar margins" (Davies 2002). Some rhyolite clasts have relict pumice textures or fine flow banding, but internal textures are commonly obscured by hydrothermal alteration. Carbonized wood is found locally and accretionary lapilli 2-8 $\mathrm{mm}$ across form up to $5 \%$ of the rock. The matrix, accounting for $40-50 \%$ of the rock, contains small wispy rhyolite fragments, broken quartz crystals, and lithic components. The $\mathrm{A} 3$ pipes in the Tepu Breccia are often larger than $30 \mathrm{~m}$ across, and the largest is $100 \mathrm{~m}$ in diameter.

Both the A4 and A3 facies contain clasts of other types of diatreme-filling rocks, including A3 clasts in A4 domains and vice-versa (e.g., Fig. 10f). This, along with the internal sub-vertical contacts between different types of pyroclastic rocks, attest to the numerous explosions responsible for generating the diatremes.

\section{Mt. Rawdon}

The Mt. Rawdon gold mine is situated in SE Queensland, Australia. Ore has been exploited from an open pit since 2001. As of 31 December 2015, 47.2 Mt of ore had been milled in total with average grades of $1.0 \mathrm{~g} / \mathrm{t} \mathrm{Au}$, representing 1.4 Moz Au and 2.4 Moz Ag recovered (S. Wangi, written. commun., 2016). Remaining resources on the same date were $56.1 \mathrm{Mt} @ 0.7 \mathrm{~g} / \mathrm{t} \mathrm{Au}$, with a cutoff of $0.2 \mathrm{~g} / \mathrm{t}$, representing 1.2 Moz Au (Evolution Mining Limited 2016).

Brooker (1991) and Brooker and Jaireth (1995) interpreted the geological setting of the Mt. Rawdon epithermal goldsilver deposit as a felsic diatreme, based on what was known in the early 1990s, before the start of mining. Two weeks of preliminary field work (mapping, core logging) have confirmed many of their observations and strongly support the diatreme interpretation. Brooker and Jaireth (1995) estimated the erosion level to be 200-600 m below the pre-eruptive surface, so the maar crater infill and the ejecta ring have been eroded.

According to the best available geological map (Fig. 11), the gold mineralization is located in the northern part of a polygonal zone, largely bound by faults. The polygonal zone containing dacitic volcaniclastic rocks and intrusive dacites is $1.45 \mathrm{~km} \mathrm{~N}-\mathrm{S}$ by $1.39 \mathrm{~km} \mathrm{E}-\mathrm{W}$ and this is interpreted here as the outline of the diatreme (Brooker and Jaireth 1995 showed a more elliptical shape). A number of dikes, ranging mostly from intermediate to felsic in composition, cut these rocks; some of the dike families are largely restricted to the diatreme. Some of the dacitic intrusions have peperitic margins where emplaced in volcaniclastic rocks, showing that they are not much younger than their hosts. U-Pb dating of zircons yielded ages of $229.7 \pm 5.3 \mathrm{Ma}$ for a dacite porphyry and $222.5 \pm$ 7.8 Ma for a "trachyte" dike (unpublished ages from the Australian National University, cited in Angus and Lewis
1996), indicating that these rocks, and presumably the undated dacitic volcaniclastic rocks which they intrude, are Late Triassic in age.

The country rocks around the diatreme consist of metasediments and schists from the Carboniferous Curtis Island Group. These are cut by pre-diatreme granitoids assigned by Brooker (1991) to the Briggs Granodiorite (apparently not shown on the map, unless included in part in the dikes). West of the diatreme, the hills are mapped as belonging to the Late Triassic Aranbanga Volcanic Group, which sits unconformably on the Curtis Island Group (Cranfield 1994). Regionally, the Aranbanga Volcanic Group consists of "several basaltic, dacitic, rhyolitic flow units, rhyolitic pyroclastics, and undivided sediments", and one of the basalts is dated at $221 \pm 4 \mathrm{Ma}$ (Cranfield 1994). Brooker and Jaireth (1995) mention a broad range of 234$214 \mathrm{Ma}$ for the Aranbanga Volcanic Group and intrusions within. The distribution, composition and age of the Aranbanga Volcanic Group immediately west of Mt Rawdon is not well established due to poor exposure and limited work; the geometrical and temporal relationships between the Aranbanga Volcanic Group and the diatreme rocks are not clear at this stage.

Dacitic volcaniclastic rocks in the diatreme are documented by drilling to vertical depths of $915 \mathrm{~m}$ below the pre-mining surface (hole MRDD203600-1 on Fig. 11) and their maximum vertical extent (i.e., the remaining depth of the diatreme after natural erosion) is not yet known. The diatreme includes three main lithofacies described in the next paragraphs.

\section{Bedded volcaniclastic rocks}

The upper $150 \mathrm{~m}$ of the volcaniclastic rocks contain some relatively thin (cm- to dm-thick) beds (Fig. 12a), mostly showing plane-parallel stratification. The sorting appears better than in the deeper volcaniclastic rocks, based on a visual assessment. Brooker and Jaireth (1995) describe cross-bedding, "rare dune structures", and "an apparent ballistic impact structure" (see Plate 20 in Brooker 1991) which leads to an interpretation of deposition from pyroclastic surges. Bedding dips at very variable angles (from near vertical to $40-50^{\circ}$ from horizontal), suggesting that "slumping occurred within the fragmental sequence" (Brooker and Jaireth 1995), or that some of this bedding may exist in megablocks derived from the upper diatreme or ejecta ring. A single accretionary lapillus has been observed within the well-bedded portion of the volcaniclastic rocks (this study; Fig. 12b), demonstrating the presence of water in the eruption column and a connection with the atmosphere at the time of the explosions.

Non-bedded to thickly bedded, poorly sorted, polymict volcaniclastic rocks

Deeper down, the volcaniclastic rocks are coarser grained (mostly lapilli tuffs), more poorly sorted, and not as clearly 
bedded. Although bedding is not readily apparent in the open pit (even at the highest elevations), some very thick beds, in the tens of meters range, are visualized in drill core based on downhole changes in componentry and grainsize, which are sometimes abrupt (suggesting a contact between two distinct beds), and rare normally graded bed tops (Fig. 12c). Brooker (1991) mentions domains of "cross-cutting polymict 'breccia' enriched in basement lithics", presumably with steep contacts, and interprets them as "emplaced by explosion from below in the pipe". In the open pit, one occurrence of a steep contact between two types of volcaniclastic rocks was seen, but it was apparently a faulted contact, so more work is needed on the topic of cross-cutting volcaniclastic zones at Mt Rawdon.

The most common macroscopic clast type in the coarser, non-bedded to thickly bedded polymict volcaniclastic rocks is juvenile dacite (Figs. 12d to $12 \mathrm{~g}$ ). The dacitic clasts are interpreted as juvenile because (1) they are very abundant; and (2) they are texturally similar to dacitic dikes and plugs which invade the diatreme, with some of the dikes having peperitic margins. Specifically, some of the larger dacite clasts have dark (hydrothermally altered) phenocrysts of mostly feldspar and lesser biotite (Fig. 12f) in a fine groundmass. This texture is also observed in dacite dikes that cross-cut the volcaniclastic rocks and the dikes are thought to be connected to the main dacite bodies (Brooker 1991). Other juvenile dacite fragments appear aphyric (Figs. 12c, 12d, 12e, 12g), although this may in part represent the groundmass material between the phenocrysts. The juvenile dacite clasts are mostly less than $5 \mathrm{~cm}$ across and are dense (non-vesicular). Flow-banding was only observed by us in a single dacite lapillus. Juvenile dacite fragments typically do not contain quartz phenocrysts.

Lithic (non-juvenile) fragments vary from minor to locally dominant. Brooker and Jaireth (1995) mention a maximum of $10 \%$ lithics, but this is an underestimate in our opinion. Lithic clasts consist of recognizable metasediments and schists from the Curtis Island Group; associated granitoids; dark clasts which may be igneous and mafic, and/or metasedimentary in origin (e.g., Fig. 12d); and rare quartz crystal-bearing silicic welded ignimbrite with fiamme (Fig. $12 \mathrm{~g})$. In relation with the latter clast type, Brooker and Jaireth (1995) describe "meter-size blocks of welded tuff" from the pre-mining surface and mention that no rocks of the same composition occur outside the diatreme. This suggests that an early episode of magmatic explosive eruptions occurred, with the products now found as fragments in the diatreme (Brooker and Jaireth 1995). On the other hand, if the Aranbanga Volcanic Group is at least partly older than the diatreme, then the ignimbrite clasts could be derived from there. Brooker (1991) also reports relatively uncommon fragments of "re-brecciated fragmental rock".
The less than $2 \mathrm{~mm}$ matrix typically represents $60-80 \%$ of the rock (Brooker and Jaireth 1995), although some intervals are richer in lapilli and blocks. The matrix contains dacite clasts; lithic fragments; quartz, derived from the basement granitoids; feldspar, derived from both the basement and juvenile dacite; amphibole and biotite; and "fibrous tuffaceous fragments" (Brooker and Jaireth 1995). Brooker (1991) states that there is a lack of fine ash in the matrix.

\section{Country rock breccias}

At several locations, the geological map shows that the diatreme margins are occupied by "breccias" of an unspecified nature (Fig. 11). Brooker (1991) and Brooker and Jaireth (1995) recorded these as "marginal basement breccias" with widths of 5-50 $\mathrm{m}$ at the surface and steep dips. They contain only metasedimentary and granitoid lithologies near the contact with the basement, i.e. they lack juvenile dacite clasts. Moving towards the center of the diatreme, the marginal breccias "grade into the diatreme fragmental sequence, with the appearance of dacite porphyry clasts, a decrease in basement fragments, and a transition to a dacitic matrix" (Brooker and Jaireth 1995). Moving away from the diatreme center, the basement breccias transition into "shattered basement" with little matrix and then into intact basement (Brooker 1991).

We examined a country rock breccia in the bottom portion of diamond drill hole MTRRCD097, which was drilled northward. This is likely equivalent to the zone of weathered country rock breccia cropping out just north of the open pit (Fig. 11). The last $\sim 2.5 \mathrm{~m}$ of the core shows monomict clast-supported country rock breccias, consisting of either granitoid clasts or metasediment and schist clasts, without mixing (Fig. 13a). This may resemble the "shattered basement" of Brooker (1991) and suggests that the hole terminated not far from intact basement or at least "shattered basement". Uphole (towards the south, i.e. the interior of the diatreme), the interval from $\sim 532 \mathrm{~m}$ to $\sim 565 \mathrm{~m}$ downhole depth is a polymict, mostly clastsupported, country rock breccia, completely devoid of macroscopic dacitic (juvenile) fragments, with mixed metasediment, schist and granitoid clasts, in a dark matrix (Fig. 13b). Locally the rock is darker and matrixsupported. Still further uphole, dacitic clasts start to appear, first a few per core tray (Fig. 13c), and eventually their abundance grades into what is normal for diatreme volcaniclastic rocks.

\section{Discussion}

In this section we first discuss the various eruptive styles responsible for generating felsic maar-diatreme volcanoes, based on the information presented above.

Phreatomagmatism is found to be the dominant eruptive style, and we elaborate on the possible details of phreatomagmatic fragmentation involving felsic magmas. We then compare felsic maar-diatreme volcanoes with 
their ultramafic/mafic counterparts, emphasizing similarities and differences. Finally we compare felsic maar-diatremes with domes surrounded by tuff rings, and with small calderas.

\section{Eruptive styles of felsic maar-diatremes volcanoes}

Three eruptive styles are variably expressed in the deposits of felsic maar-diatreme volcanoes: phreatomagmatism, intrusive/extrusive phases, and explosive magmatic activity.

\section{Dominance of phreatomagmatism}

Several writers have stated that felsic maar-diatremes are phreatomagmatic volcanoes (e.g., Sillitoe and Bonham 1984; Sillitoe 1985; Sillitoe et al. 1985; Brooker and Jaireth 1995; Carrasco-Núñez and Ort 2012; Lorenz and Suhr 2012; Palladino et al. 2015), partly by analogy with their ultramafic to mafic counterparts. Using only evidence summarized in this review and relating to felsic maardiatremes, phreatomagmatism must be the dominant eruptive style to explain the following features: (i) deep diatremes (sometimes over $1 \mathrm{~km}$ deep) with abundant lithic clasts, signifying efficient country rock fragmentation; (ii) evidence for water in the eruption column and deposits of the ejecta ring, such as bomb sags, accretionary lapilli, or tuff with soft-sediment deformation; (iii) dense to poorly vesicular juvenile clasts being typical of, or abundant in, the ejecta ring and diatreme; (iv) at Tepexitl, juvenile ash in the 4 phi size fraction being dominated by dense blocky particles with features such as stepped fractures, branching quench cracks, and pitting.

The dominance of phreatomagmatism and the presence of deep diatremes with abundant lithics imply that fragmentation occurred underground and that groundwater was available. External water can have come from a porous granular aquifer (e.g., Tepexitl), but also from faults, since felsic maar-diatreme volcanoes often lie along, or at the intersection of, regional faults (e.g., Cerro de Pasco, Hoya de Estrada, Montana Tunnels, Tepexitl, Wau; see also Corbett and Leach 1998). These faults further channeled the felsic magma and may in some cases have controlled, in part, the diatreme location and shape.

The dominance of phreatomagmatism in felsic maardiatreme volcanoes also implies relatively modest longterm eruptive rates, otherwise magma would not interact explosively with the aquifer (Valentine and White 2012; Valentine et al. 2014). Because the magma involved is generally quite dense, and because plugs and domes are commonly formed towards the end of the eruption, we envisage felsic maar-diatremes as generated by dome-like eruptions strongly modified by phreatomagmatism. Therefore, eruptive rates may be dome-like, perhaps in the $10^{3}-10^{4} \mathrm{~kg} / \mathrm{s}$ range (e.g., Pyle 2000), with durations of years to decades for the largest felsic maar-diatremes. The volumes of felsic-maar-diatremes are also relatively small, no more than a few $\mathrm{km}^{3}$ for the largest diatremes (diatreme deposits including lithics and pore space; Table 1). We elaborate on how felsic phreatomagmatism may work below.

\section{Intrusivelextrusive phases}

The intrusion and extrusion of mostly dense felsic magma into, or near, existing maar-diatremes creates dikes, plugs and domes. These are often the last, or nearly the last, preserved phases of the eruption, although older intrusions and domes were probably formed but subsequently destroyed by explosions.

\section{Explosive magmatic phases}

Some of the beds in the Mexican tuff rings may have been formed by explosive magmatic phases (see discussion in the Tepexitl section). A portion of the diatreme infill at Cerro de Pasco has features compatible with an explosive magmatic style (see above for descriptive details) and ignimbrite clasts are reported in several diatremes (Montana Tunnels, Mt Rawdon, Wau). However the timing, duration and volume of products for the magmatic explosive style are not firmly established for many felsic maar-diatremes. At Cerro de Pasco for example, the timing of the crystal-rich volcaniclastic rocks containing glass shards, relative to the ordinary (phreatomagmatic) diatreme infill, is unclear. Ignimbrite clasts from Wau are sourced from deposits that are about $1 \mathrm{~m}$.y. older than the maar. At Montana Tunnels, there are some ignimbrites which have approximately the same radiometric age as the diatreme, but there could still be a significant time gap between ignimbrite generation and the diatreme-forming eruptions. At Mt Rawdon, the welded ignimbrite fragments contain quartz crystals, whereas the dacitic juvenile fragments in the diatreme lack quartz phenocrysts. So for many felsic maar-diatremes, the products of the magmatic explosive style may not have been formed by the same batch of magma, and may be significantly older, although more detailed volcanological and geochronological studies are needed to resolve this. Even in cases where magmatic explosive activity is maar-related, this style must play a relatively minor role over time, otherwise the landform would differ. The possible exceptions are Cerro de Pasco and Guinaoang, which may be hybrid volcanoes between maars and small calderas, as discussed below.

\section{Details of phreatomagmatic fragmentation}

It is interesting to speculate on how felsic magma interacts explosively with aquifers, and how this may differ from the situation with mafic to ultramafic magmas. In lowviscosity magmas, it is generally thought that the first step in an explosive interaction (molten fuel coolant interaction, MFCI, leading to a thermohydraulic explosion) is a coarse premix (i). The coarse premix is a dispersion of domains of low-viscosity magma into the aquifer, or more likely, domains of water or wet sediment into the magma (Zimanowski et al. 1997b). This is followed by (ii) vapor film destabilization allowing direct contact between the magma and liquid water, (iii) rapid heat transfer and fine 
fragmentation, and (iv) expansion (e.g., Zimanowski et al. 1997a). Hydrodynamic mixing efficiency, which controls the premix, depends on a limited viscosity contrast between the magma and the aquifer (Zimanowski and Büttner 2002). Therefore a coarse premix seems more difficult to achieve with a felsic magma, since the viscosity contrast is large. Felsic peperites (e.g., Hanson and Wilson 1993) may be evidence of such premixes, but they probably did not explode since they are preserved as peperite.

Explosive interaction of rhyolite with water is possible in the laboratory (Austin-Erickson et al. 2008), but was achieved using a different configuration than the classic one involving mafic to ultramafic magmas and water injection. The experiments reported by Austin-Erickson et al. (2008) involved remelting Tepexitl rhyolitic material in a crucible; specifically, the material chosen for melting was stony rhyolite, as it did not tend to vesiculate during fast melting. A layer of liquid water was added on top of the magma, less than one second before the start of deformation. Compressed air, injected from below, domed up the magma, which cracked. Liquid water flowed into the cracks, coming in direct contact with the hot magma and allowing rapid heat transfer. Experiments were also performed without adding the liquid water for comparative purposes. Particles in the 4 phi $(0.063 \mathrm{~mm})$ size fraction differed between the 'dry' and the 'wet' experiments. Those generated in the wet experiments were typical "active" particles (cf. Büttner et al. 1999).

In a natural setting, one can envisage a felsic dike or plug rising in a granular aquifer, or perhaps in an existing diatreme. At shallow depths, the highly viscous margins of the plug or dike fracture and heal repeatedly because of flow-related strain (Tuffen et al. 2003; Rust et al. 2004). This is not due to phreatomagmatism, but to the processes occurring in the margins of the flowing felsic magma. However, these temporary fractures may permit infiltration of external water, or fluidized/liquefied sediment, in the felsic magma, allowing phreatomagmatic explosions to occur (Austin-Erickson et al. 2008, 2011). This mechanism should work better for low magma fluxes, and lowvesicularity magmas, since gas bubbles dampen or even suppress the explosivity of phreatomagmatic interactions (Zimanowski et al. 1995).

\section{Comparison with ultramafic to mafic maar-diatremes: similarities}

The similarities between felsic maar-diatremes, and their better known ultramafic to mafic counterparts (White and Ross 2011 and references therein), are numerous. First, felsic maar-diatreme volcanoes can occur in groups (e.g., Cerro de Pasco, Kelian, Montana Tunnels), as is the case for many mafic monogenetic volcanoes and felsic domes (e.g., Nemeth and Kereszturi 2015).
Second, the overall structure of the volcano (maar crater with ejecta ring around it and diatreme underneath) is thought to be the same (Figs. 14a, 14b). The dimensions of the craters and diatreme diameters and depths associated with felsic maars are generally similar to those for maficultramafic counterparts (White and Ross 2011). Many of the felsic maar-diatremes reviewed here are relatively large, but those of the Saar-Nahe basin are only "several tens to hundreds of meters in diameter" (Lorenz and Haneke 2004), so we expect that the full spectrum of sizes exist from a few tens of meters to kilometers.

Third, ultramafic/mafic maar-diatreme volcanoes commonly, but not always, evolve into scoria cones or lava lakes that partly or totally fill their craters when the aquifer water runs out or the eruptive rate increases (e.g., Lorenz 1986; White 1991; White and Ross 2011, Kereszturi et al. 2014; and references therein) (Fig. 14c). A comparable evolution in eruptive style occurs in some felsic maardiatremes and tuff rings: phreatomagmatism is responsible for the overall shape of the volcano and generating the bulk of its pyroclastic deposits, but there is often a latestage evolution towards dryer phreatomagmatism, magmatic explosive eruptions and/or lava dome formation. This shift is manifested in the character of the upper parts of the ejecta rings (Hoya de Estrada, Tepexitl), in the preservation of extrusive domes (Wau) and as thick dikes and plugs in the diatremes (Cerro de Pasco, Guinaoang, Kelian, Montana Tunnels, Mt Rawdon), which may have fed domes or lavas at the surface (Fig. 14b). If the dome/lava phase constitutes a major part of the eruptive history of a felsic volcano, then it may look more like a dome, with an underlying or surrounding pyroclastic ring (Fig. 14d). This ring may be phreatomagmatic or partly magmatic in origin (Heiken and Wohletz 1987), as discussed below. Other evolutions in eruptive style are possible, for example some mafic maar-diatremes have an initial scoria cone phase, or have frequently changing eruptive styles (e.g., Valentine and White 2012 and references therein), and such possible evolutions may also apply to felsic maar-diatremes and other small felsic volcanoes.

Fourth, ultramafic/mafic and felsic ejecta rings (in maars and tuff rings) have a similar thickness and distribution. Features such as low-angle cross-bedding, dune bedforms, undulating beds, and channels, are typical of deposition from pyroclastic surges, and found in both ultramafic/mafic and felsic examples (e.g., Hoya de Estrada, Tepexitl). Bomb sags, soft-sediment deformation and accretionary lapilli indicate water in the eruption column and in the deposits. Both ultramafic/mafic and felsic ejecta rings contain pyroclastic fall deposits (Hoya de Estrada, Tepexitl, Wau). Pyroclastic deposits in ultramafic/mafic and felsic ejecta rings are mostly in the tuff and lapilli tuff size range, and contain mixtures of juvenile and lithic clasts in variable proportions. The abundance of lithic fragments is an indication that the 
diatreme is being excavated in the country rocks and that the source of external water is typically groundwater. Ejecta rings consist of tens to hundreds of beds, which suggests a pulsatory eruptive style.

Fifth, felsic diatreme deposits are very similar to their ultramafic to mafic counterparts, in that they are mostly poorly sorted, relatively coarse (lapilli tuff to tuff breccia), heterolithic deposits (Cerro de Pasco, Guinaoang, Kelian, Montana Tunnels, Mt Rawdon, Wau). The lithic fragments are from a range of depths (e.g., Montana Tunnels) and are mixed together. In the deeper portions of both felsic and ultramafic/mafic diatremes, the pyroclastic deposits tend to be non-bedded (Guinaoang, Kelian, Montana Tunnels). Lack of bedding in the lower diatreme has been attributed to destruction of bedding (White 1991), fallback of pyroclasts into the vent (White 1991; Porritt et al. 2008; Ross et al. 2013), fluidization (Sparks et al. 2006; Walters et al. 2006), and debris jets (see below). Despite the common lack of bedding, bedded pyroclastic megablocks are often found at depth (Cerro de Pasco, Kelian). The deposits in these bedded pyroclastic megablocks formed in the ejecta ring or syn-eruptive crater floor, but progressively subsided into the diatreme as megablocks. Mt Rawdon has very thick beds, the origin of which is currently unclear. These "megabeds" (>10 m thick) also occur in the deeper parts of some kimberlite diatremes (e.g., Mwadui: Stiefenhofer and Farrow 2004; Jericho: Hayman and Cas 2011) and are defined by changes in component types and grainsize. Non-bedded pyroclastic deposits in felsic or ultramafic/mafic diatremes can consist of sub-vertical columns with different grain sizes and componentries, suggesting multiple explosions and migrating vent sites (Kelian, Montana Tunnels, possibly Mt Rawdon). The columns in ultramafic/mafic diatremes are typically interpreted as formed by the passage of debris jets (White 1991; Ross and White 2006; Ross et al. 2008a, 2008b; White and Ross 2011; Valentine and White 2012; Lefebvre et al. 2013). Fragments of one pyroclastic facies in another (Kelian) also suggest multiple explosions and migrating vent sites. The margins of both ultramafic/mafic and felsic diatremes are sometimes occupied by country rock breccias (Kelian, Mt Rawdon), and megablocks of country rocks can occur (Cerro de Pasco, Montana Tunnels).

Sixth, juvenile fragments in both ultramafic/mafic and felsic maar-diatremes may have a range of vesicularities, since external water can meet the rising magma at any stage in its vesiculation and degassing history (Ross and White 2012 and references therein), but the clasts are often dense to poorly vesicular (e.g., Mt Rawdon, Tepexitl).

Seventh, crater lakes can form in felsic maars (Wau) or ultramafic/mafic maars, which is also indicative of external water being present (although no lake is currently present in the Mexican tuff rings reviewed here). These posteruptive craters become filled with remobilized pyroclastic deposits from the ejecta ring, and a range of sediments, including lacustrine sediments (Wau).

Both the upper diatreme beds and the post-eruptive crater infill can display centroclinal dips, which indicates subsidence, occurring during and/or after the eruption (Cerro de Pasco, Wau). The role of subsidence in ultramafic/mafic diatremes has been discussed by Suhr et al. (2006), White and Ross (2011) and Delpit et al. (2014).

\section{Differences with ultramafic to mafic maar-diatremes}

There are of course some differences between felsic maardiatremes and their ultramafic/mafic equivalents. In the Trans-Mexican Volcanic Belt, many mafic maars currently contain a lake whereas the felsic tuff rings reviewed here do not, indicating shallower craters (Carrasco-Núñez and Ort 2012). This may also mean shallower fragmentation and limited country rock excavation for the felsic tuff rings in Mexico, although the final level of the crater is in part a function of the late eruptive activity which may fill the crater, and post-eruptive sedimentation. However, not all felsic maar-diatremes are characterized by shallow excavation, as shown by numerous examples of deep diatremes (up to $1 \mathrm{~km}$ or more) cited in this review.

The dikes and plugs feeding and invading felsic diatremes seem larger (Fig. 14b) than most of the dikes related to mafic to ultramafic ones (Fig. 14a). Wider conduits appear to be needed for the more viscous felsic magmas to ascend to surface (Carrasco-Núñez and Ort 2012). Specifically, the feeder dikes of kimberlitic diatremes tend to be less than $1 \mathrm{~m}$ across (e.g., Mitchell 1986; Gurney and Menzies 1998; Lorenz and Kurszlaukis 2007). The feeder dikes of mafic maar-diatremes can be somewhat wider, for example the minette dike NE of Ship Rock, Navajo volcanic field, New Mexico, has an average thickness of $2.3 \mathrm{~m}$ (Delaney and Pollard 1981), although a minette dike south of the Cathedral Cliff diatreme, in the same volcanic field, is only about $1 \mathrm{~m}$ across on average (Ross, unpublished observation). Valentine et al. (2014) have compiled the sizes of mostly mafic intrusions in and around some diatremes, and list some larger examples including pods reaching $100 \mathrm{~m}$ across. The present review shows that felsic intrusions in diatremes are often large: $90 \mathrm{~m}$ wide quartz latite porphyry dikes at Montana Tunnels; interpenetrating dacitic porphyries each 100-500 $\mathrm{m}$ across at Cerro de Pasco; a rhyolite plug $550 \mathrm{~m}$ by $300 \mathrm{~m}$ across at Kelian (see above).

There are several other important differences. The composition and some textures of the juvenile pyroclasts are obviously different in felsic versus ultramafic/mafic maar-diatremes (e.g., mineralogy, flow banding). The processes of phreatomagmatic explosions involving felsic magmas may be different too, as discussed above. The eruption of the largest felsic maar-diatreme volcanoes, by analogy with felsic domes, may have lasted years to 
decades, compared to the days to months typically envisaged for mafic to ultramafic maar-diatremes (e.g., Kienle et al. 1980).

\section{Comparison with domes surrounded by tuff rings}

Examples of felsic domes surrounded by tuff rings include Cerro Pinto in Mexico (Zimmer et al. 2010), Panum Crater in California, USA (Sieh and Bursik 1986), the Ramadas Volcanic Centre in Argentina (Tait et al. 2009), Puketarata in New Zealand (Brooker et al. 1993) and Sugarloaf Mountain in Arizona, USA (Heiken 1974; Sheridan and Updike 1975), among others (Heiken and Wohletz 1987).

Sugarloaf Mountain consists of a tuff ring up to $75 \mathrm{~m}$ thick surrounding a lava dome $150 \mathrm{~m}$ high and about $1 \mathrm{~km}$ across. According to Sheridan and Updike (1975), the tuff ring consists entirely of pyroclastic surge deposits of phreatomagmatic origin. It is surrounded by a much more widespread ("several kilometers"), 3-10 m thick, pyroclastic fall deposit which consists mostly of "large, angular, highly vesiculated pumice lapilli" probably formed by an early magmatic explosive phase. In contrast, at Puketarata, the distal fall deposit is interpreted as phreatomagmatic by Brooker et al. (1993).

Cerro Pinto is a rhyolitic tuff ring-dome complex, with four rings and four domes, located in the Serdán-Oriental basin of Mexico (Zimmer et al. 2010), not far from the Tepexitl tuff ring described above. At Cerro Pinto, pyroclastic deposits are dominated by pumiceous fall deposits, from sub-Plinian sustained-column activity (Zimmer et al. 2010). Although the early parts of each eruptive cycle were phreatomagmatic, fragmentation continued under the influence of magma vesiculation. Subsequently, domes were built in a periodic way. The activity was cyclic at Cerro Pinto, and phreatomagmatism was less important than for other volcanoes including the nearby Tepexitl tuff ring.

It is tempting to draw parallels between tuff ring-dome complexes and the felsic maar-diatremes described here. They feature the same three eruptive styles in variable proportions: magmatic explosive activity forming pumiceous pyroclastic fall deposits and perhaps some ignimbrites; phreatomagmatic explosive activity, forming an ejecta ring and, if this style persists over time, a diatreme; effusive and intrusive activity, forming lava domes and plugs. Thus, maar-diatremes are volcanoes for which the phreatomagmatic eruptive style dominates over the other two styles, whereas effusive activity was more successful at tuff ring-dome complexes, and in some cases, phreatomagmatism was minor.

\section{Comparison with small calderas}

The smallest calderas overlap in size with the largest felsic maar-diatremes (Nemeth et al. 2009; Lorenz and Suhr 2012; Palladino et al. 2015). They are both characterized by more or less circular depressions surrounded by a relatively thin package of pyroclastic deposits. Therefore, examination of the eruptive products, not only the landforms, is necessary to distinguish one from another. The maar ejecta rings will be dominantly phreatomagmatic, and the caldera pyroclastic deposits mostly magmatic, although maar-diatremes can have magmatic explosive phases, while calderas can have phreatomagmatic phases. Palladino et al. (2015) describe transitional or 'hydrid' cases between the two types of volcanoes. Cerro de Pasco and Guinaoang may be examples of hydrid volcanoes, however, most of the other cases compiled here seem firmly in the phreatomagmatic maar-diatreme (and tuff ring) camp. They involved relatively small volumes of magma and, presumably, dome-like eruptive rates, to allow explosive magma-water interaction.

\section{Outlook}

Although the diatreme interpretations are rather convincing in the examples selected for this review, most of the diatremes mentioned here would probably benefit from further work by volcanologists (although access may not be possible anymore since several mines have closed). Felsic maar-diatremes are far from as well studied as their ultramafic to mafic counterparts, but this volcanological review has compiled what is currently known about them, focusing on the best documented examples. Felsic maardiatremes are important economically: among the 14 largest circum-Pacific epithermal gold deposits reviewed by Sillitoe (1997), three or four occur in or near felsic diatremes, making this the most common volcanic setting for that deposit type, along with flow-dome complexes. It is hoped that the information presented here will assist economic geologists in evaluating whether a certain ore deposit sits in a diatreme or not, and which structural level they are dealing with in the volcano. It is also hoped that this review will inspire some volcanologists to dig into the economic geology literature, or even use drill cores and mining exposures to study volcanoes!

\section{Acknowledgements}

The initial manuscript was written while P.-S.R. was on sabbatical at Queensland University of Technology (QUT) in Brisbane, Australia. P.-S.R. acknowledges Discovery Grant funding from NSERC. Brian Jicha dated the Tepexitl sample and partial support for dating was provided by Conacyt grant CB-150900 to G.C.N. Evolution Mining Limited is acknowledged for logistical support during field work at Mt. Rawdon. Samson Wangi in particular is thanked for sharing his knowledge of the geology there and facilitating everything. T. Watson showed the senior author some interesting core intervals at Mt Rawdon. James D.L. White made useful comments on an early draft of the manuscript. We thank Karoly Nemeth, Dick Sillitoe, and Greg Valentine for constructive comments on the submitted version, which helped to significantly improve the paper. Acting executive editor 
Steve Self is thanked for final suggestions on the revised version.

\section{References}

Angus M, Lewis RW (1996) Mt. Rawdon gold project feasibility study, volume 1 - geology. Internal company report, Placer Pacific Ltd, Sydney NSW, Australia, 59 p.

Austin-Erickson A, Büttner R, Dellino P, Ort MH, Zimanowski B (2008) Phreatomagmatic explosions of rhyolitic magma: experimental and field evidence. J. Geophys. Res. 113:paper B11201

Austin-Erickson A, Ort MH, Carrasco-Núñez G (2011) Rhyolitic phreatomagmatism explored: Tepexitl tuff ring (Eastern Mexican Volcanic Belt). J. Volcanol. Geotherm. Res. 201:325-341

Baumgartner R (2007) Sources and evolution in space and time of hydrothermal fluids at the Cerro de Pasco Cordilleran base metal deposit, central Peru. PhD thesis, Université de Genève, Switzerland, $167 \mathrm{p}$.

Baumgartner R, Fontboté L, Vennemann T (2008) Mineral zoning and geochemistry of epithermal polymetallic Zn$\mathrm{Pb}-\mathrm{Ag}-\mathrm{Cu}-\mathrm{Bi}$ mineralization at Cerro de Pasco, Peru. Econ. Geol. 103:493-537

Baumgartner R, Fontboté L, Spikings R, Ovtcharova M, Schaltegger U, Schneider J, Page L, Gutjahr M (2009) Bracketing the age of magmatic-hydrothermal activity at the Cerro de Pasco epithermal polymetallic deposit, central Peru: a U-Pb and ${ }^{40} \mathrm{Ar} /{ }^{39} \mathrm{Ar}$ study. Econ. Geol. 104:479-504

Bendezú R, Fontboté L, Cosca M (2003) Relative age of Cordilleran base metal lode and replacement deposits, and high sulfidation $\mathrm{Au}-(\mathrm{Ag})$ epithermal mineralization in the Colquijirca mining district, central Peru. Mineralium Deposita 38:683-694

Brooker M (1991) Geology, alteration and mineralization of the Mount Rawdon diatreme-hosted gold deposit. MSc thesis, James Cook University of North Queensland, Australia, $180 \mathrm{p}$.

Brooker M, Jaireth S (1995) Mount Rawdon, Southeast Queensland, Australia; a diatreme-hosted gold-silver deposit. Econ. Geol. 90:1799-1817

Brooker MR, Houghton BF, Wilson CJN, Gamble JA (1993) Pyroclastic phases of a rhyolitic dome-building eruption: Puketarata tuff ring, Taupo Volcanic Zone, New Zealand. Bull. Volc. 55:395-406

Buchel G, Lorenz V (1993) Syn- and post-eruptive mechanism of the alaskan Ukinrek maars in 1977. In: Negendank JFW, Zolitschka B (eds) Paleolimnology of European Maar Lakes, Lecture Notes in Earth Sciences 49, pp 15-60

Bull KF, McPhie J (2007) Fiamme textures in volcanic successions: flaming issues of definition and interpretation. J. Volcanol. Geotherm. Res. 164:205-216

Büttner R, Dellino P, Zimanowski B (1999) Identifying magmawater interaction from the surface features of ash particles. Nature 401:688-690

Cano-Cruz M (2007) Evolución del volcán Hoya de Estrada. MSc thesis, Universidad Nacional Autónoma de México, 136 p.

Cano-Cruz M, Carrasco-Núñez G (2008) Evolución de un cráter de explosión (maar) riolítico: Hoya de estrada, campo volcánico valle de Santiago, Guanajuato, México [Evolution of a rhyolitic explosion crater (maar): Hoya de Estrada, Valle de Santiago volcanic field, Guanajuato,
Mexico]. Revista Mexicana de Ciencias Geologicas 25:549-564

Carrasco-Núñez G, Ort M (2012) Rhyolitic and basaltic maar volcanoes, a perspective from Mexican volcanism [extended abstract]. Forth International Maar Conference, Auckland, New Zealand, Abstract volume, p. 21-22. (https://vhub.org/resources/1435/download/4IMC_Abstra ct_Volume.pdf)

Carrasco-Núñez G, Ort MH, Romero C (2007). Evolution and hydrological conditions of a maar volcano (Atexcac crater, Eastern Mexico). J. Volcanol. Geotherm. Res. 159:179-197.

Cas RAF, Wright JV (1987) Volcanic successions, modern and ancient. Allen \& Unwin, London, 528 p.

Cashman KV, Scheu B (2015) Magmatic fragmentation. In: Sigurdsson H, Houghton B, McNutt SR, Rymer H, Stix J (eds) Encyclopedia of Volcanoes, Second edition. Academic Press, London, pp 459-471

Cashman KV, Sturtevant B, Papale P, Navon O (2000) Magmatic fragmentation. In: Sigurdsson H, Houghton B, McNutt SR, Rymer H, Stix J (eds) Encyclopedia of Volcanoes. Academic Press, London, pp 421-430

Chough SK, Sohn YK (1990) Depositional mechanics and sequences of base surges, Songaksan tuff ring, Cheju Island, Korea. Sedimentology 37:1115-1135

Cranfield LC (1994) Maryborough - Sheet SG56-6, 1:250,000 Geological Series - Explanatory Notes. Geological Survey of Queensland, Brisbane, Australia, $120 \mathrm{p}$.

Corbett GJ, Leach TM (1998) Southwest Pacific Rim goldcopper systems: structure, alteration, and mineralization. Society of Economic Geologists, Special Publication 6, $238 \mathrm{p}$.

Davies AGS (2002) Geology and genesis of the Kelian gold Deposit, East Kalimantan, Indonesia. PhD thesis, University of Tasmania, Australia.

Davies AGS, Cooke DR, Gemmell JB, van Leeuwen T, Cesare P, Hartshorn G (2008a) Hydrothermal breccias and veins at the Kelian gold mine, Kalimantan, Indonesia: genesis of a large epithermal gold deposit. Econ. Geol. 103:717-757

Davies AGS, Cooke DR, Gemmell JB, Simpson KA (2008b) Diatreme breccias at the Kelian gold mine, Kalimantan, Indonesia: precursors to epithermal gold mineralization. Econ. Geol. 103:689-716

Delaney PT, Pollard DD (1981) Deformation of host rocks and flow of magma during growth of minette dikes and breccia-bearing intrusions near Ship Rock, New Mexico. US Geological Survey, Professional Paper 1202, 61 p.

Delpit S, Ross P-S, Hearn BC (2014) Deep-bedded ultramafic diatremes in the Missouri River Breaks volcanic field, Montana, USA: $1 \mathrm{~km}$ of syn-eruptive subsidence. Bull. Volc. 76:Art. 832

Erickson AA (2007) Phreatomagmatic eruptions of rhyolitic magma: a case study of Tepexitl tuff ring, SerdánOriental basin, Mexico. MSc thesis, Northern Arizona University, USA, $234 \mathrm{p}$.

Evolution Mining Limited (2016) Annual mineral resources and ore reserves statement, 21 April 2016, 66 p. Downloaded from http://www.evolutionmining.com.au on June 8, 2016.

Fisher RV, Waters AC (1970) Base surge forms in maar volcanoes. Am. J. Sci. 268:157-180

Gençalioğlu-Kuşcu G, Nemeth K, Stewart RB (2012) Morphological and chemical diversity of maars in Central Anatolian Volcanic Province (Turkey). Fourth 
international maar conference, Auckland, New Zealand; Abstract volume, p. 31-32

Gifkins CC, Allen RL, McPhie J (2005) Apparent welding textures in altered pumice-rich rocks. J. Volcanol. Geotherm. Res. 142:29-47

Graettinger AH, Valentine GA, Sonder I, Ross P-S, White JDL (2015) Facies distribution of ejecta in analog tephra rings from experiments with single and multiple subsurface explosions. Bull. Volc. 77:Article 66

Gurney JJ, Menzies AH (1998) Small mines field guide. Seventh International Kimberlite Conference, Cape Town, 40 p.

Hanson RE, Wilson TJ (1993) Large-scale rhyolitic peperites (Jurassic, southern Chile). J. Volcanol. Geotherm. Res. 54:247-264

Hayman PC, Cas RAF (2011) Reconstruction of a multi-vent kimberlite eruption from deposit and host rock characteristics: Jericho kimberlite, Nunavut, Canada. J. Volcanol. Geotherm. Res. 200:201-222

Heiken G (1974) An atlas of volcanic ash. Smithsonian Contributions to the Earth Sciences No. 12, 101 p.

Heiken G, Wohletz K (1987) Tephra deposits associated with silicic domes and lava flows. In: Fink JH (ed) The Emplacement of Silicic Domes and Lava Flows. Geological Society of America, Special Paper 212, p. 5576

Hewson N, Leary S, Feier N (2005) Tarina and Rodu: gold mineralisation hosted in maar-diatreme contact environments in the Apuseni Mountains, Romania. AuAg-Te-Se deposits, Proceedings of the 2005 Field Workshop, Kiten, Bulgaria, p. 93-101

Howell FH, Molloy JS (1960) Geology of the Braden orebody, Chile, South America. Econ. Geol. 55:863-905

Kereszturi G, Németh K, Cronin SJ, Procter J, Agustín-Flores J (2014) Influences on the variability of eruption sequences and style transitions in the Auckland Volcanic Field, New Zealand. J. Volcanol. Geotherm. Res. 286:101-115

Kienle J, Kyle PR, Self S, Motyka R, Lorenz V (1980) Ukinrek Maars, Alaska, I. Eruption sequence, petrology and tectonic setting. J. Volcanol. Geotherm. Res. 7:11-37

Lefebvre NS, White JDL, Kjarsgaard BA (2013) Unbedded diatreme deposits reveal maar-diatreme-forming eruptive processes: Standing Rocks West, Hopi Buttes, Navajo Nation, USA. Bull. Volc. 75:1-17

Leys CA (1983) Volcanic and sedimentary processes during formation of the Saefell tuff-ring, Iceland. Transactions of the Royal Society of Edinburgh: Earth Sciences 74:1522

Lorenz V (1973) On the formation of maars. Bull. Volc. 37:183204

Lorenz V (1986) On the growth of maars and diatremes and its relevance to the formation of tuff rings. Bull. Volc. 48:265-274

Lorenz V (2007) Syn- and posteruptive hazards of maar-diatreme volcanoes. J. Volcanol. Geotherm. Res. 159:285-312

Lorenz V, Haneke J (2004) Relationship between diatremes, dykes, sills, laccoliths, intrusive-extrusive domes, lava flows, and tephra deposits with unconsolidated watersaturated sediments in the late Variscan intermontane Saar-Nahe Basin, SW Germany. In: Breitkreuz C, Petford $\mathrm{N}$ (eds) Physical geology of high-level magmatic systems. Geological Society, London, Special Publication 234, pp 75-124

Lorenz V, Kurszlaukis S (2007) Root zone processes in the phreatomagmatic pipe emplacement model and consequences for the evolution of maar-diatreme volcanoes. J. Volcanol. Geotherm. Res. 159:4-32

Lorenz V, Zimanowski B (2008) Volcanology of the West Eifel maars and its relevance to the understanding of kimberlite pipes [fieldtrip guidebook]. Ninth International Kimberlite Conference, Frankfurt am Main, Germany, 84 p.

Lorenz V, Suhr P (2012) On differences and similarities between maar-diatreme volcanoes and explosive collapse calderas. Fourth international maar conference, Auckland, New Zealand; Abstract volume, p. 58-59

Manske SL, Hedenquist JW, O'Connor G, Tămaş C, Cauuet B, Leary S, Minut A (2006) Roşia Montană, Romania: Europe's largest gold deposit: Society of Economic Geologists Newsletter 64:1-15

Mitchell RH (1986) Kimberlites: mineralogy, geochemistry and petrology. Plenum Press, New York, 442 p.

Németh K, Kereszturi G (2015) Monogenetic volcanism: personal views and discussion. International Journal of Earth Sciences 104:2131-2146

Nemeth K, Risso C, Maeno F (2009) Different eruption mechanisms forming similar landforms; large maars and small calderas from Argentina and Japan. Programme with Abstracts, International Geomorphology Conference, Melbourne, Australia, Abstract no. 50

Ort MH, Carrasco-Núñez G (2009) Lateral vent migration during phreatomagmatic and magmatic eruptions at Tecuitlapa maar, east-central Mexico. J. Volcanol. Geotherm. Res. 181:67-77.

Palladino DM, Valentine GA, Sottili G, Taddeucci J (2015) Maars to calderas: end-members on a spectrum of explosive volcanic depressions. Frontiers in Earth Science 3, article 36

Pirrung M, Büchel G, Lorenz V, Treutler H-C (2008) Posteruptive development of the Ukinrek East Maar since its eruption in 1977 A.D. in the periglacial area of southwest Alaska. Sedimentology 55:305-334

Porritt LA, Cas RAF, Crawford BB (2008) In-vent column collapse as an alternative model for massive volcaniclastic kimberlite emplacement: an example from the Fox kimberlite, Ekati Diamond Mine, NWT, Canada. J. Volcanol. Geotherm. Res. 174:90-102

Pyle DM (2000) Sizes of volcanic eruptions. In: Sigurdsson H, Houghton B, McNutt SR, Rymer H, Stix J (eds) Encyclopedia of Volcanoes. Academic Press, London, pp 263-269

Rogers RD (1983) Structural and geochemical evolution of a mineralized volcanic vent at Cerro de Pasco, Peru. PhD thesis, University of Arizona, USA

Ross P-S, White JDL (2006) Debris jets in continental phreatomagmatic volcanoes: a field study of their subterranean deposits in the Coombs Hills vent complex, Antarctica. J. Volcanol. Geotherm. Res. 149:62-84

Ross P-S, White JDL (2012) Quantification of vesicle characteristics in some diatreme-filling deposits, and the explosivity levels of magma-water interactions within diatremes. J. Volcanol. Geotherm. Res. 245-246:55-67

Ross P-S, White JDL, Zimanowski B, Büttner R (2008a) Rapid injection of particles and gas into non-fluidized granular material: volcanological implications. Bull. Volc. 70:1151-1168

Ross P-S, White JDL, Zimanowski B, Büttner R (2008b) Multiphase flow above explosion sites in debris-filled volcanic vents: insights from analogue experiments. J. Volcanol. Geotherm. Res. 178:104-112 
Ross P-S, Delpit S, Haller MJ, Németh K, Corbella H (2011) Influence of the substrate on maar-diatreme volcanoes an example of a mixed setting from the Pali Aike volcanic field, Argentina. J. Volcanol. Geotherm. Res. 201:253-271

Ross P-S, White JDL, Valentine GA, Taddeucci J, Sonder I, Andrews RG (2013) Experimental birth of a maardiatreme volcano. J. Volcanol. Geotherm. Res. 260:1-12

Rottas KM, Houghton BF (2012) Structure, stratigraphy, and eruption dynamics of a young tuff ring: Hanauma Bay, O’ahu, Hawai'i. Bull. Volc. 74:1683-1697

Rust AC, Cashman KV, Wallace PJ (2004) Magma degassing buffered by vapor flow through brecciated conduit margins. Geology 32:349-352

Schaefer J (2012) Montana Tunnels Mining, Inc., Mine Redevelopment: Part II. Presentation given at the Montana Tech Mine Design, Operations \& Closure Conference, downloaded from http://www.mtech.edu/mwtp/conference/2012 presentati ons/John\%20Schaefer.pdf on March 3, 2016

Sheridan MF, Updike RG (1975) Sugarloaf Mountain tephra - a Pleistocene rhyolitic deposit of base-surge origin in northern Arizona. Geol. Soc. Am. Bull. 86:571-581

Sieh K, Bursik M (1986) Most recent eruption of the Mono Craters, eastern central California. J. Geophys. Res. 91:12539-12571

Silberman ML, Noble DC (1977) Age of igneous activity and mineralization, Cerro de Pasco, central Peru. Econ. Geol. 72:925-930

Sillitoe RH (1985) Ore-related breccias in volcanoplutonic arcs. Econ. Geol. 80:1467-1514

Sillitoe RH (1994) Indonesian mineral deposits - introductory comments, comparisons and speculations. J. Geochem. Explor. 50:1-11

Sillitoe RH (1997) Characteristics and controls of the largest porphyry copper-gold and epithermal gold deposits in the circum-Pacific region. Australian Journal of Earth Sciences 44:373-388

Sillitoe RH, Bonham HF (1984) Volcanic landforms and ore deposits. Econ. Geol. 79:1286-1298

Sillitoe RH, Angeles CA (1985) Geological characteristics and evolution of a gold-rich porphyry copper deposit at Guinaoang, Luzon, Philippines. In: Asian Mining' 85, Institution of Mining and Metallurgy, London, pp 15-26

Sillitoe RH, Baker EM, Brook WA (1984) Gold deposits and hydrothermal eruption breccias associated with a maar volcano at Wau, Papua New Guinea. Econ. Geol. 79:638655

Sillitoe RH, Grauberger GL, Elliott JE (1985) A diatreme-hosted gold deposit at Montana Tunnels, Montana. Econ. Geol. 80:1707-1721

Sillitoe RH, Tolman J, Van Kerkvoort G (2013) Geology of the Caspiche porphyry gold-copper deposit, Maricunga belt, northern Chile. Econ. Geol. 108: 585-604

Skewes MA, Arévalo A, Floody R, Zuñiga PH, Stern CR (2002) The giant El Teniente breccia deposit: hypogene copper distribution and emplacement. In: Goldfarb RJ, Nielsen RL (eds) Integrated Methods for Discovery: Global Exploration in the $21^{\text {st }}$ Century. Society of Economic Geologists, Special Publication 9, pp 299-332

Sparks RSJ, Baker L, Brown RJ, Field M, Schumacher J, Stripp G, Walters A (2006) Dynamical constraints on kimberlite volcanism. J. Volcanol. Geotherm. Res. 155:18-48
Stiefenhofer J, Farrow DJ (2004) Geology of the Mwadui kimberlite, Shinyanga district, Tanzania. Lithos 76:13960

Suhr P, Goth K, Lorenz V (2006) Long lasting subsidence and deformation in and above maar-diatreme volcanoes - a never ending story. Zeitschrift der Deutschen Gesellschaft für Geowissenschaften 157:491-511

Taddeucci J, Valentine GA, Sonder I, White JDL, Ross P-S, Scarlato P (2013) The effect of pre-existing craters on the initial development of explosive volcanic eruptions: an experimental investigation. Geophys. Res. Lett. 40:507510

Tămaş CG, Minuţ A (2012) Cetate Breccia, Roşia Montana, Romania - a dacite-related Au-Ag mineralized maardiatreme structure. Fourth international maar conference, Auckland, New Zealand; Abstract volume, p. 89-90

Tait MA, Cas RAF, Viramonte JG (2009) The origin of an unusual tuff ring of perlitic rhyolite pyroclasts: the last explosive phase of the Ramadas Volcanic Centre, Andean Puna, Salta, NW Argentina. J. Volcanol. Geotherm. Res. 183:1-16

Thompson TB, Trippel AD, Dwelley PC (1985) Mineralized veins and breccias of the Cripple Creek District, Colorado. Econ. Geol. 80:1669-1688

Tuffen H, Dingwell DB, Pinkerton H (2003) Repeated fracture and healing of silicic magma generate flow banding and earthquakes? Geology 31:1089-1092

Valentine GA, White JDL (2012) Revised conceptual model for maar-diatremes: subsurface processes, energetics, and eruptive products. Geology 40:1111-1114

Valentine GA, Graettinger AH, Sonder I (2014) Explosion depths for phreatomagmatic eruptions. Geophys. Res. Lett. 41:2014GL060096

Valentine GA, Graettinger AH, Macorps E, Ross P-S, White JDL, Döhring E, Sonder I (2015) Experiments with vertically- and laterally-migrating subsurface explosions with applications to the geology of phreatomagmatic and hydrothermal explosion craters and diatremes. Bull. Volc. 77:Art 15, doi:10.1007/s00445-015-0901-7

van Otterloo J, Cas RAF (2016) Low-temperature emplacement of phreatomagmatic pyroclastic flow deposits at the monogenetic Mt Gambier Volcanic Complex, South Australia, and their relevance for understanding some deposits in diatremes. J. Geol. Soc. 173:701-710

Vazquez JA, Ort MH (2006) Facies variation of eruption units produced by the passage of single pyroclastic surge currents, Hopi Buttes volcanic field, USA. J. Volcanol. Geotherm. Res. 154:222-236

Wallier S, Rey R, Kouzmanov K, Pettke T, Heinrich CA, Leary S, O'Connor G, Tămaş CG, Vennemann T, Ullrich T (2006) Magmatic fluids in the breccia-hosted epithermal $\mathrm{Au}-\mathrm{Ag}$ deposit of Roşia Montană, Romania. Econ. Geol. 101:923-954

Walters AL, Phillips JC, Brown RJ, Field M, Gernon T, Stripp G, Sparks RSJ (2006) The role of fluidisation in the formation of volcaniclastic kimberlite: grain size observations and experimental investigation. J. Volcanol. Geotherm. Res. 155:119-137

White JDL (1989) Basic elements of maar-crater deposits in the Hopi Buttes volcanic field, northeastern Arizona, USA. J. Geol. 97:117-125

White JDL (1991) Maar-diatreme phreatomagmatism at Hopi Buttes, Navajo Nation (Arizona), USA. Bull. Volc. $53: 239-258$ 
White JDL, Schmincke H-U (1999) Phreatomagmatic eruptive and depositional processes during the 1949 eruption on La Palma (Canary Islands). J. Volcanol. Geotherm. Res. 94:283-304

White JDL, Houghton BF (2006) Primary volcaniclastic rocks. Geology 34:677-680

White JDL, Ross P-S (2011) Maar-diatreme volcanoes: a review. J. Volcanol. Geotherm. Res. 201:1-29

White JDL, Valentine GA (2016) Magmatic versus phreatomagmatic fragmentation: absence of evidence is not evidence of absence. Geosphere, DOI 10.1130/GES01337.1

Woolsey TS, McCallum ME, Schumm SA (1975) Modeling of diatreme emplacement by fluidization. First international conference on kimberlites, Physics and Chemistry of the Earth 9, Pergamon, pp 11-24

Zimanowski B, Büttner R (2002) Dynamic mingling of magma and liquefied sediments. J. Volcanol. Geotherm. Res. 114:37-44
Zimanowski B, Fröhlich G, Lorenz V (1991) Quantitative experiments on phreatomagmatic explosions. J. Volcanol. Geotherm. Res. 48:341-358

Zimanowski B, Fröhlich G, Lorenz V (1995) Experiments on steam explosion by interaction of water with silicate melts. Nuclear Engineering and Design 155:335-343

Zimanowski B, Büttner R, Lorenz V, Häfele H-G (1997a) Fragmentation of basaltic melt in the course of explosive volcanism. J. Geophys. Res. 102:803-814

Zimanowski B, Büttner R, Lorenz V (1997b) Premixing of magma and water in MFCI experiments. Bull. Volc. $58: 491-495$

Zimanowski B, Büttner R, Delino P, White JDL, Wohletz K (2015) Magma-water interaction and phreatomagmatic fragmentation. In: Sigurdsson H, Houghton B, McNutt SR, Rymer H, Stix J (eds) Encyclopedia of Volcanoes, Second edition. Academic Press, London, pp 473-484

Zimmer BW, Riggs NR, Carrasco-Núñez G (2010) Evolution of tuff ring-dome complex: the case study of Cerro Pinto, eastern Trans-Mexican Volcanic Belt. Bull. Volc. 72:1223-1240 


\section{Figures}

Fig. 1. Information from the Hoya de Estrada rhyolitic tuff ring in Mexico, mostly obtained from Cano-Cruz and Carrasco-Núñez (2008). (a) Location map within central part of the Trans-Mexican Volcanic Belt. (b) Local geology (coordinates are longitude/latitude), Hoyuela and H. Blanca are other incomplete volcanic structures. (c) Photo of undulating contact (marked) between lower unit and upper unit. (d) Undulating beds and duneforms showing flow direction from left to right in the lower unit (members B and C).

Fig. 2. Composite stratigraphic column for Hoya de Estrada (a), median diameter (b), sorting (c), lapilli componentry (d) and schematic interpretation of eruptive sequence (e) for Hoya de Estrada, translated from CanoCruz and Carrasco-Núñez (2008). Only non-indurated samples have been analyzed in (b)-(d). This figure omits the mafic spatter accumulation in the crater of the felsic tuff ring, which was the last event.

Fig. 3. Photos of well bedded tuff ring deposits at Hoya de Estrada. (a) Cross-bedding in Member A. (b) Member B showing an alternation of clast-supported lapilli layers with fine indurated ash, some showing some soft-deformation structures. (c) Block sag within cross-bedded ash deposits in lower portion of Member C. (d) Upper part of Member $\mathrm{C}$ showing a stratified sequence comprising clast-supported lapilli layers and matrix-supported ashy layers. (e) Overview of upper unit. (f) Detail of Member D showing plane parallel bedding filling irregular paleotopography in an undulating contact with member C. Gardening tool on (a), (b) and (c) is about $25 \mathrm{~cm}$ high whereas camera case on (d) is about $10 \mathrm{~cm}$ high. (a)-(d) and (f) are new photos whereas (e) is from Cano-Cruz and Carrasco-Núñez (2008).

Fig. 4. Information from Tepexitl rhyolitic maar in Mexico, simplified from Austin-Erickson et al. (2008). (a) Location map. (b) Geologic map. (c) Half cross-section A-A', see map (b) for location. (d) Composite stratigraphic section, marked CS on (b), with summary of componentry trends for the 2 phi fraction (armored lapilli are omitted for ease of visualization). Map coordinates are longitude/latitude. Note different scale between map and crosssection.

Fig. 5. Geologic map and cross-section of Wau maar (diatreme)-dome complex, simplified from Sillitoe et al. (1984). Rocks of the Wau complex are in yellow and orange colors. Map coordinates are longitude/latitude. Note different scale between map and cross-section.

Fig. 6. Interpretative E-W cross-sections of Wau maar (diatreme)-dome complex, redrawn from (a) Sillitoe et al. (1984); (b) Corbett and Leach (1998). See text for discussion.

Fig. 7. Geologic map and cross-section of Montana Tunnels diatreme, Montana, simplified from Sillitoe et al. (1985). Rocks of the diatreme, delimited by the red line, include the diatreme 'breccia', three quartz latite porphyry dikes, domains of brecciated Upper Elkhorn Mountain Volcanics, and domains of Lowland Creek Volcanics. The value of 0.02 ounces of gold per ton is approximately $0.6 \mathrm{~g} / \mathrm{t} \mathrm{Au}$. Map coordinates are probably a local grid; center of current open pit mine (not shown) is located at about longitude $112.132^{\circ} \mathrm{W}$, latitude $46.373^{\circ} \mathrm{N}$. Note different scale between map and cross-section.

Fig. 8. Geologic map and cross-sections of Cerro de Pasco diatreme-dome complex. Map is simplified from Baumgartner et al. (2009) and features UTM coordinates. Cross-sections are modified from Rogers (1983) and show bedding in Rumiallana Agglomerate and flow foliation in dacite porphyries. Note that the geology shown on the sections does not correspond exactly to that of the map, and that the location of sections on the map is approximate, since they come from different sources.

Fig. 9. Map and cross-section of Kelian diatremes, simplified from Davies et al. (2008b). Approximate location of drill holes on map, and trace of cross-section, taken from Davies (2002). Map coordinates are a local grid; center of former open pit (not shown) is located at about latitude $0.027^{\circ} \mathrm{S}$ and longitude $115.443^{\circ} \mathrm{E}$.

Fig. 10. Photos of diatreme infills at Kelian (extracted from Davies 2002 in accordance with the University of Tasmania standard copyright license). (a) Country rock breccia (A1 facies) with clasts of carbonaceous mudstone and pyrite (PYR) vein fragments in Runcing Breccia. (b) Megablock of bedded pyroclastic rocks (facies B1-B2) within non-bedded pyroclastic rocks (facies A4, see text for details) in Runcing Breccia. (c) Bedded pyroclastic 
rocks (facies B1) in Runcing Breccia. (d) Accretionary lapilli (AL) within B1-B2 facies, Runcing Breccia. (e)-(f) A4 facies in Tepu Breccia and Burung Breccia, respectively, showing clasts of carbonaceous mudstone/sandstone (marked 'c'), volcaniclastic siltstone/sandstone (marked ' $\mathrm{v}$ '), andesite, and rhyolite (QP, QFP). One clast of facies $\mathrm{A} 3$ is also present in (f). These non-bedded pyroclastic rocks are cut by pyrite \pm sphalerite veins (stages $2 \mathrm{~A}$ or $3 \mathrm{~A}$ of Davies 2002). (g)-(h) A3 facies in Tepu Breccia, including a wispy QP clast with ragged margins in (g).

Fig. 11. Pre-mining geological map of Mt. Rawdon diatreme, simplified from a late 1990s company map, itself based largely on Angus and Lewis (1996). Outline of current open pit is added, along with areas covered by mining activities and some diamond drill holes mentioned in this paper $(1=$ MRDD204469-1; $2=$ MTRRCD097; $3=$ MRDD204240-1; 4 = MRDD204250-2; 5 = MRDD203600-1; 6 = MRDD7203700-1). Drill hole DDH12 is not shown but its approximate location is $\sim 250 \mathrm{~m}$ east of \#4. Grid is Australian Map Grid zone 56 (AGD84).

Fig. 12. Photos of dacitic volcaniclastic rocks from Mt. Rawdon diatreme. (a) Thin beds of coarse tuff and fine lapilli tuff in DDH12, near $215 \mathrm{~m}$ downhole depth. (b) Accretionary lapillus (outlined) at 2.2 m in MRDD204469-1. The core of porphyritic juvenile dacite is surrounded by a rim of gray ash several mm thick. (c) Ashy top of normally graded bed at $678.3 \mathrm{~m}$ in MRDD203600-1. Stratigraphic younging is uphole (leftward on the photo). (d) Lithic-rich lapilli tuff near $359 \mathrm{~m}$ in MRDD204240-1. (e) Juvenile-rich lapilli tuff near $360 \mathrm{~m}$ in MRDD204240-1. (f) Two large juvenile dacite clasts with dark phenocrysts at about $291 \mathrm{~m}$ in MRDD204250-2. (g) Coarse lapilli tuff containing clasts of welded ignimbrite, the largest of which is outlined, in MRDD7203700-1. Abbreviations: $\mathrm{D}=$ dark clast (see text); $\mathrm{G}=$ granitoid clast; $\mathrm{J}=$ juvenile dacite clast; $\mathrm{WI}=$ welded ignimbrite clast.

Fig. 13. Photos of country rocks breccias from Mt. Rawdon diatreme, drill hole MTRRCD097. (a) Monomict clastsupported breccia formed of either metasediment and schist (first two rows), or granitoid (bottom row), near 566.2 $\mathrm{m}$ downhole depth. (b) Polymict breccia containing clasts of metasediment, schist and granitoid, within a dark matrix, at about $556.3 \mathrm{~m}$. (c) Polymict breccia with a dark matrix (first and third row). In middle row, matrix is locally greener, and one juvenile dacite clasts occurs near red arrow. About $528.5 \mathrm{~m}$. Abbreviations: $\mathrm{G}=$ granitoid clast; $\mathrm{J}=$ juvenile dacite clast; $\mathrm{S}=$ schist fragment.

Fig. 14. Generalized cross-sections of maar-diatreme volcanoes: (a) ultramafic-mafic (modified from Lorenz and Zimanowski 2008) and (b) felsic (this study, with inspiration from Sillitoe et al. 1984, Brooker and Jaireth 1995, and Corbett and Leach 1998). For felsic maar-diatremes, the approximate structural level of the seven main localities reviewed here is indicated. There are no felsic domes preserved at Hoya de Estrada and Tepexitl. Dikes in the felsic diatreme may have peperitic margins (not illustrated). A root zone is not shown for felsic diatremes because of a lack of documentation, and stock-like body of dacite or rhyolite under the diatreme is hypothetical. Distribution of country rock breccias is very schematic. Also shown are cases where magmatic activity, whether explosive or effusive, becomes dominant late in the volcano's life: (c) ultramafic-mafic diatreme overlain by a scoria cone (modified from White 1991); (d) felsic dome within a pyroclastic ring (redrawn from Heiken and Wohletz 1987 with the possible diatreme added).

Supplementary Figure S1: Ar-Ar dating results for Tepexitl tuff ring. See main text for sample information and methods.

Tables

Table 1. Summary of some important features of the seven reviewed localities. 
a

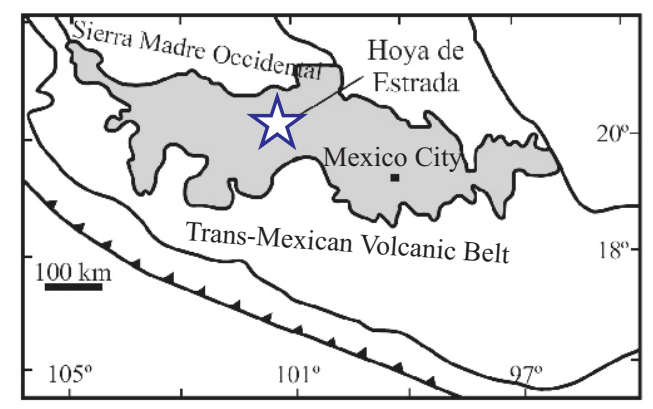

b

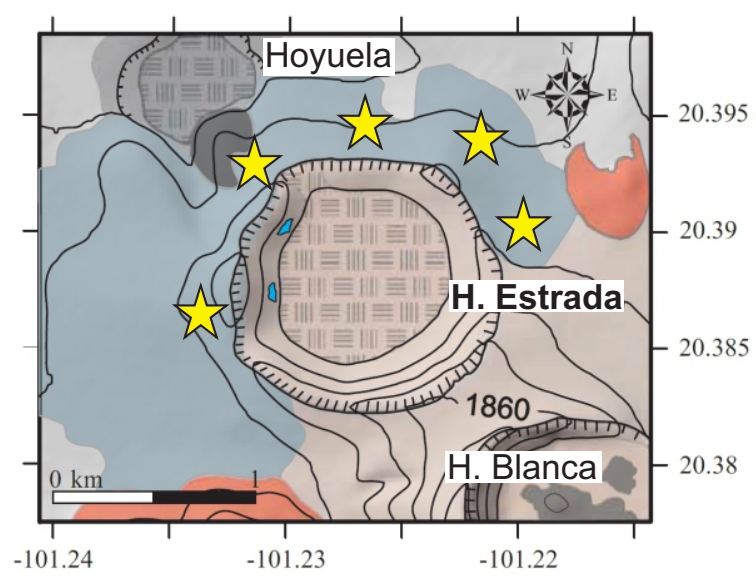

$-101.24$

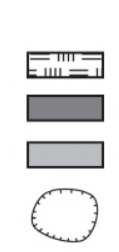

Legend
Alluvium $\square$ Hoya Blanca
Scoria cone
Hoyuela
Crater rim $\hat{W}$ Logged sections
Scoria cone
Scoria deposit Hoya de Estrada
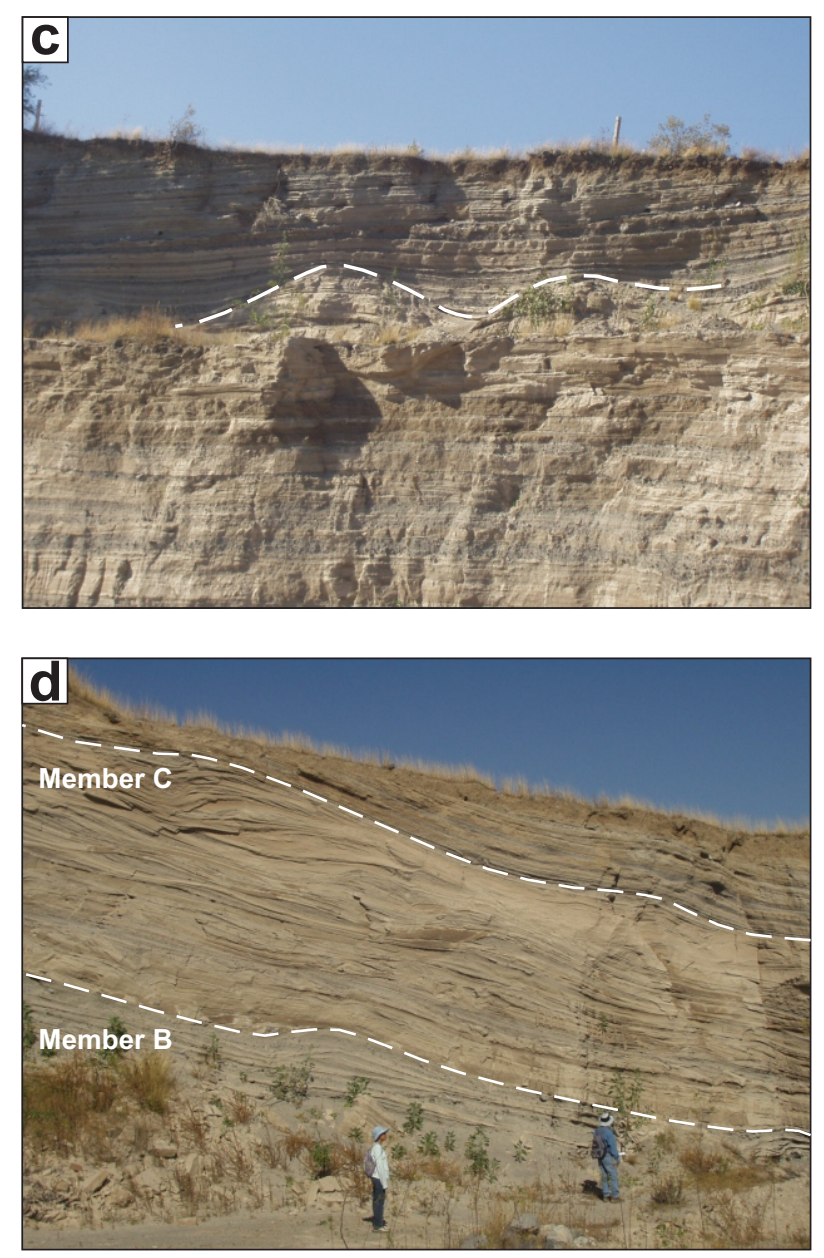

Ross et al., Fig. 1 
a

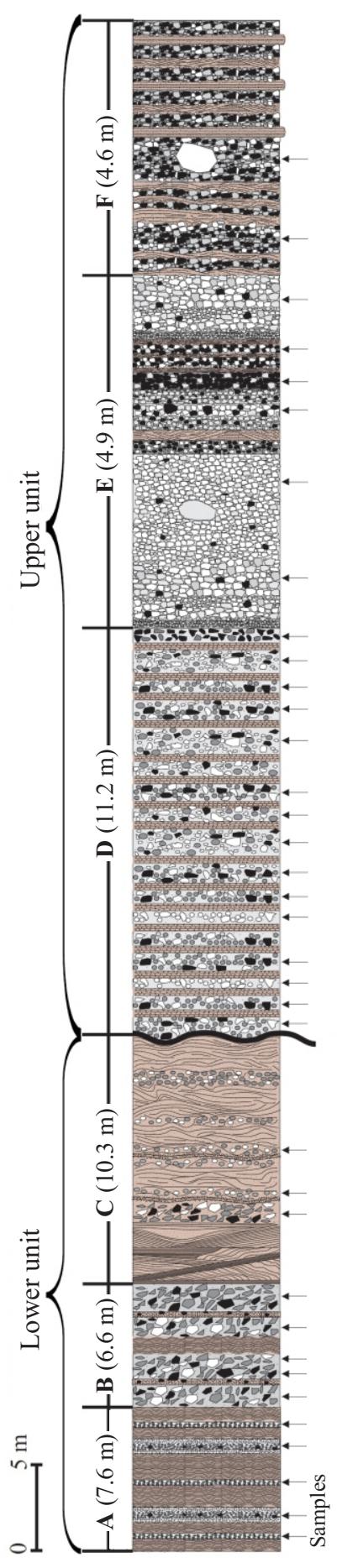

$\uparrow$

- Rhyolite

- Lithic clast

a Rhyolitic pumice b

C

Median diameter Sorting
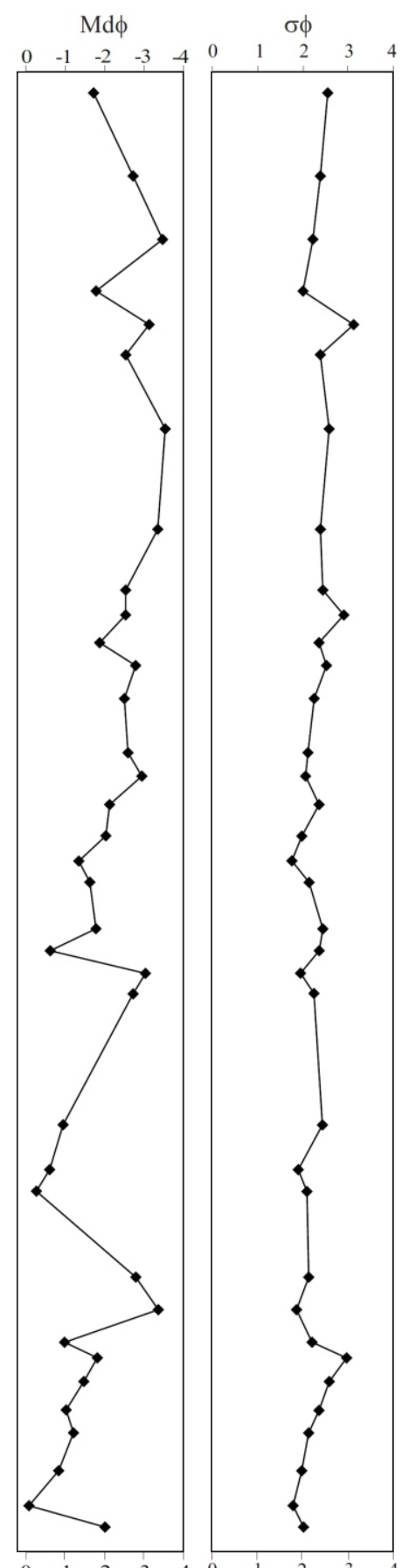

d
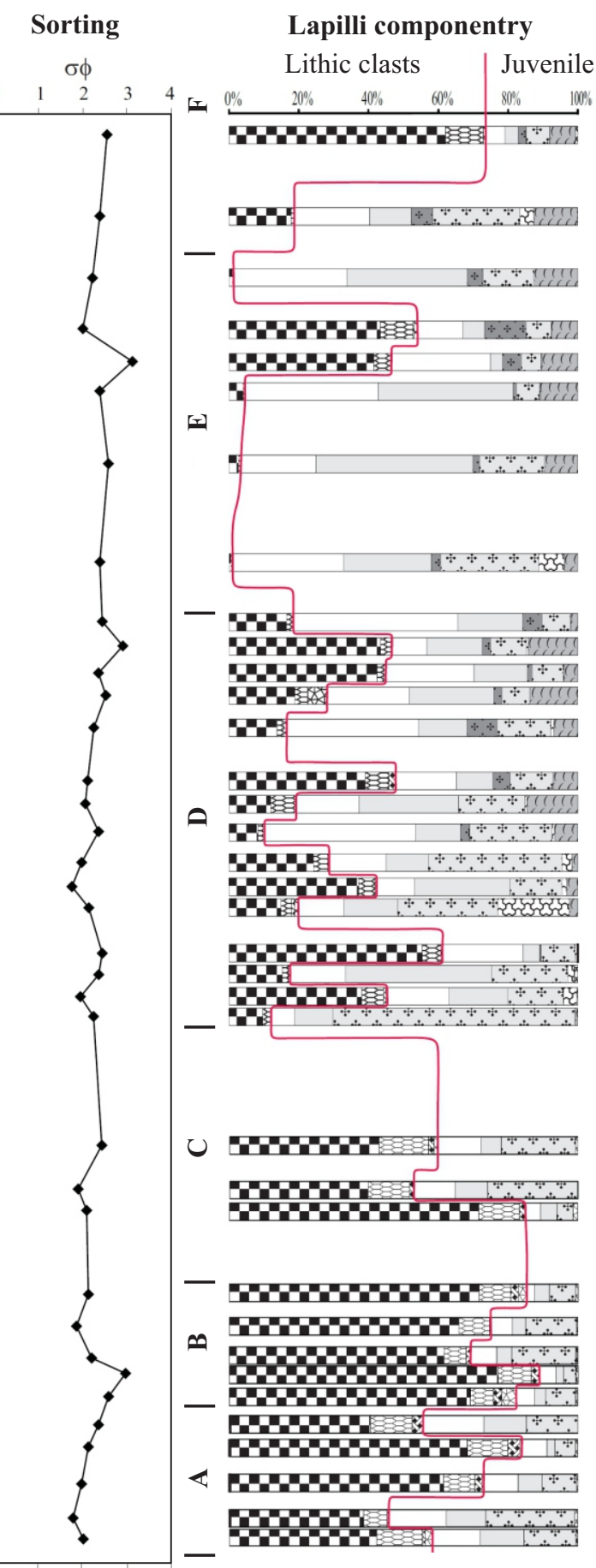

\begin{tabular}{lllll}
$00 \%$ & $20 \%$ & $40 \%$ & $60 \%$ & $80 \%$ \\
\hline
\end{tabular}

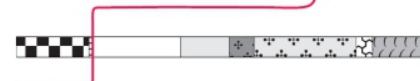

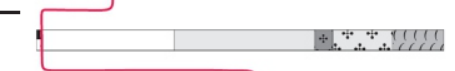

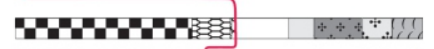

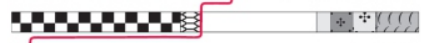

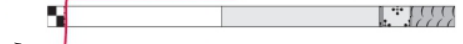

되
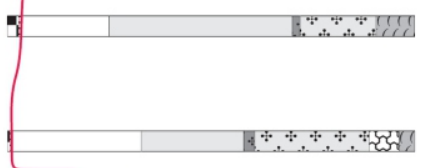

두를

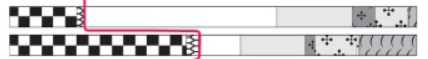

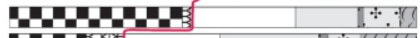

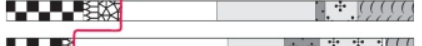

In-

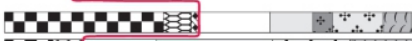

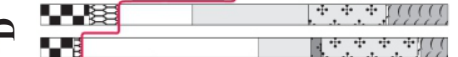

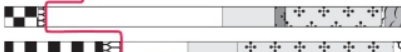

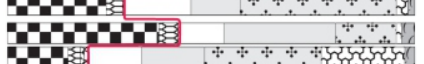

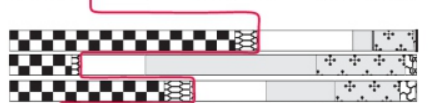

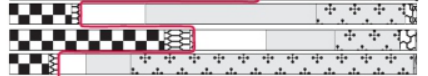

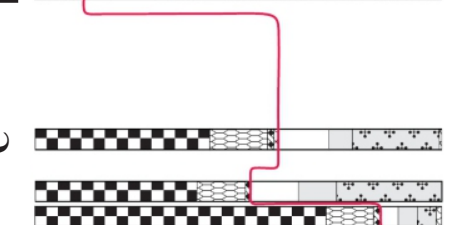

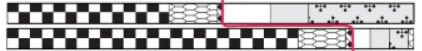

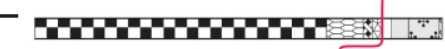

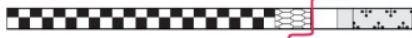

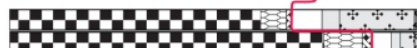

CDC

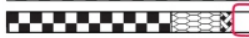

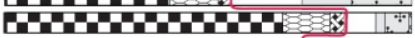

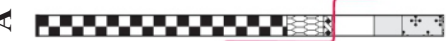

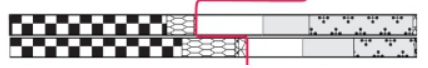

\section{-}

Lithic clasts

D Andesite

图 Altered and/or oxidized

Basaltic scoria

Altered vesicular basalt

圂 Agglomerate e
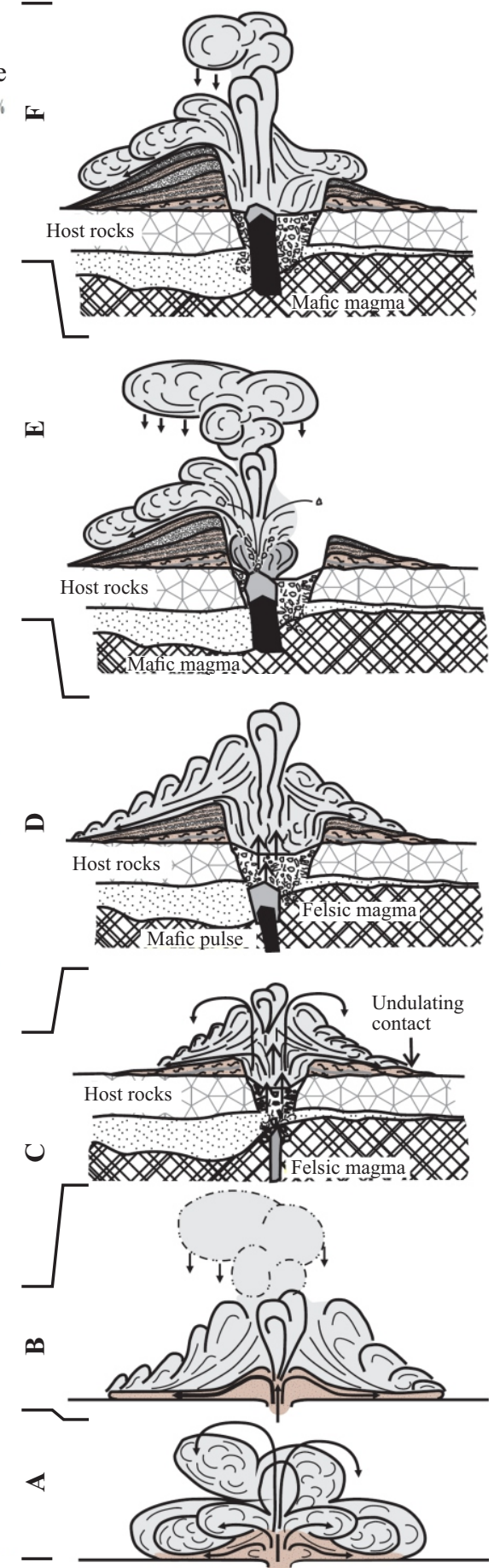

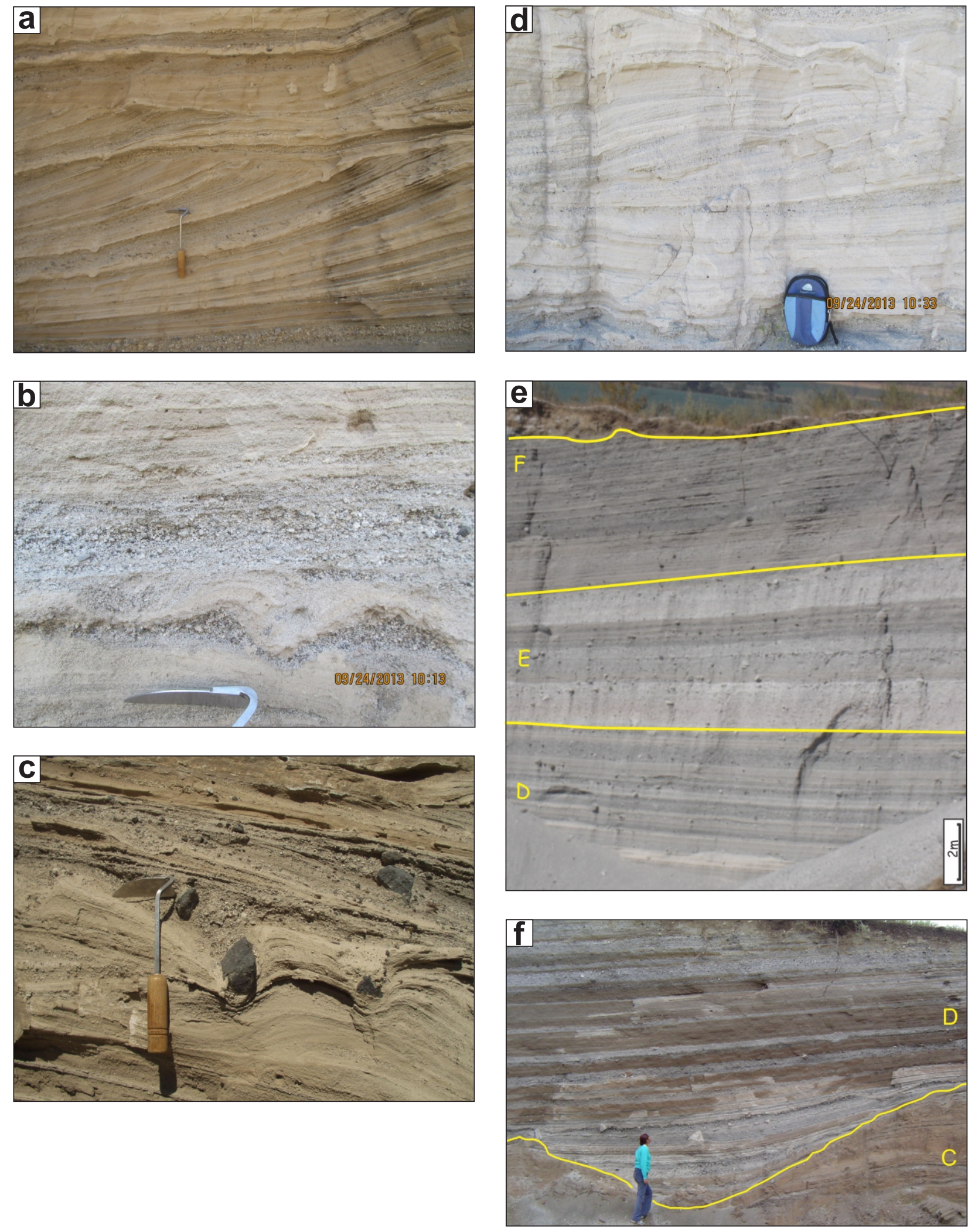

Ross et al., Fig. 3 
a

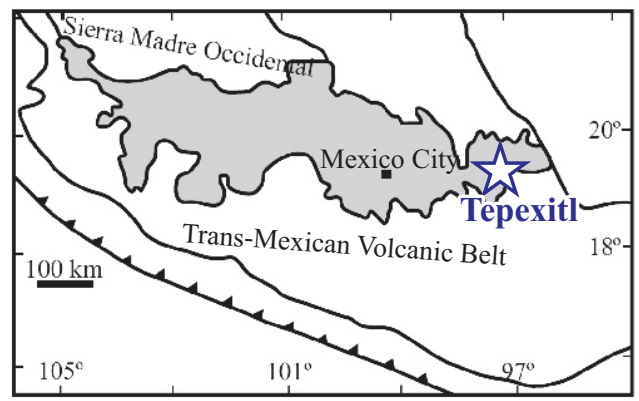

b

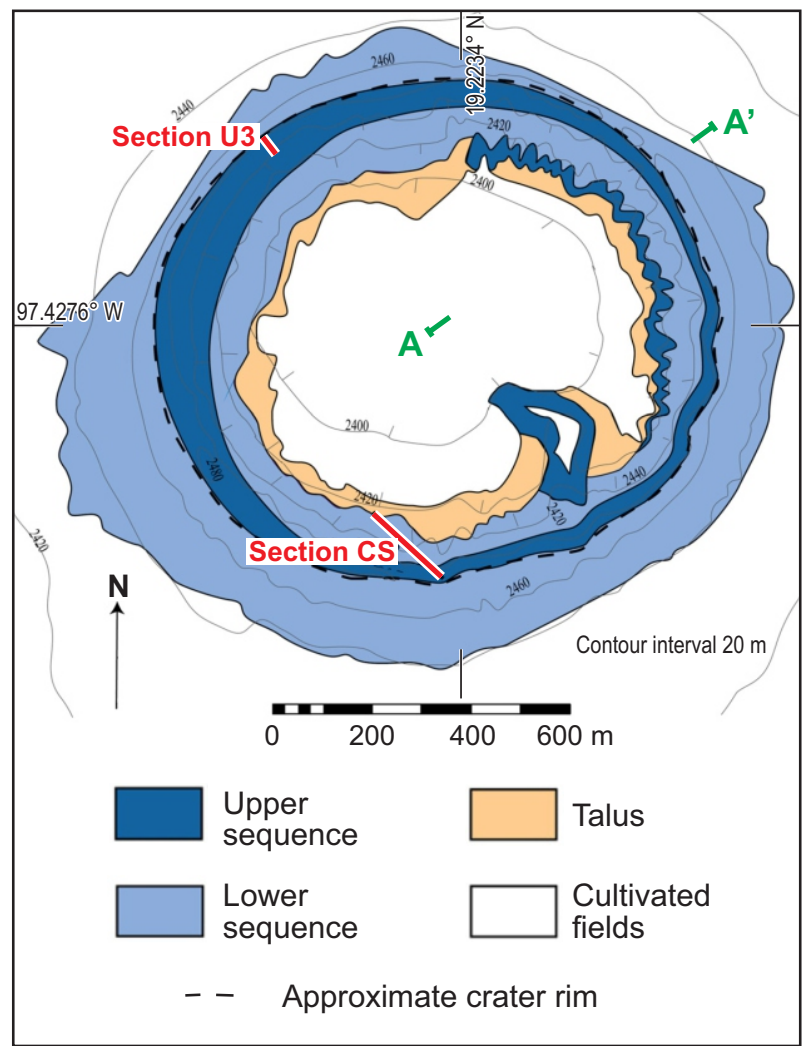

\section{C}
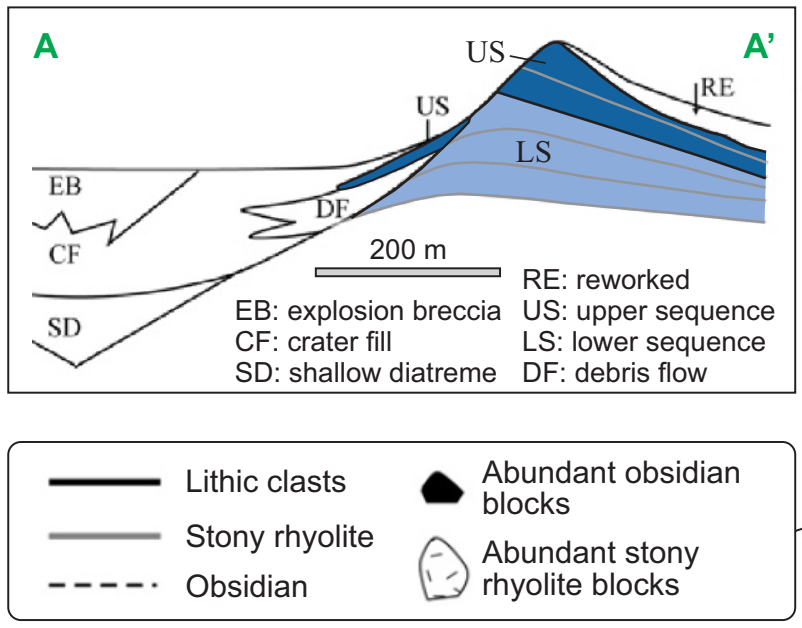

d

U2

U1

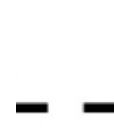

L5

L4
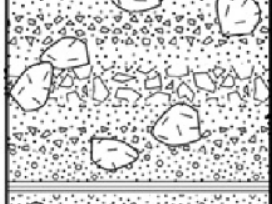

Q.6.

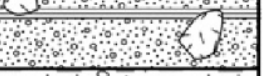

0000

$\frac{1-0.6}{-0}$

$0 ?$
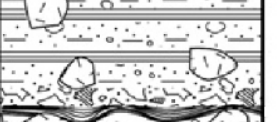

$7 \quad 0009$
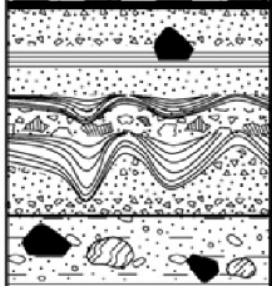

10
0
0
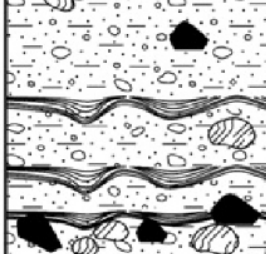

L3

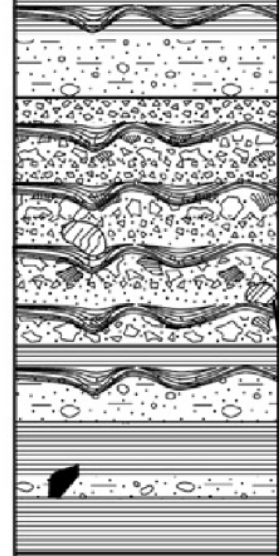

L2

L1<smiles></smiles>

55

$m$

(1)
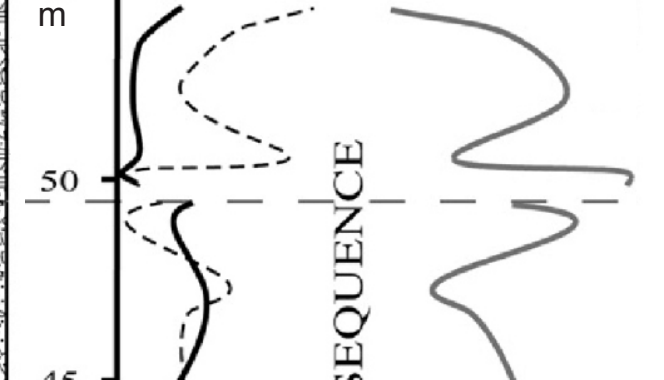

45
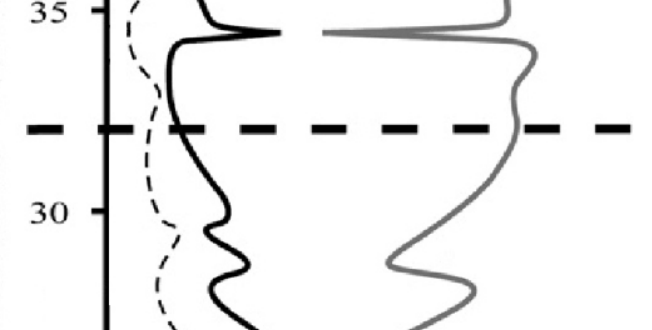

-
25

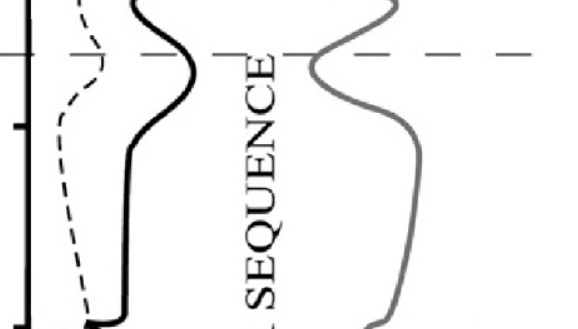

20

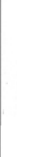

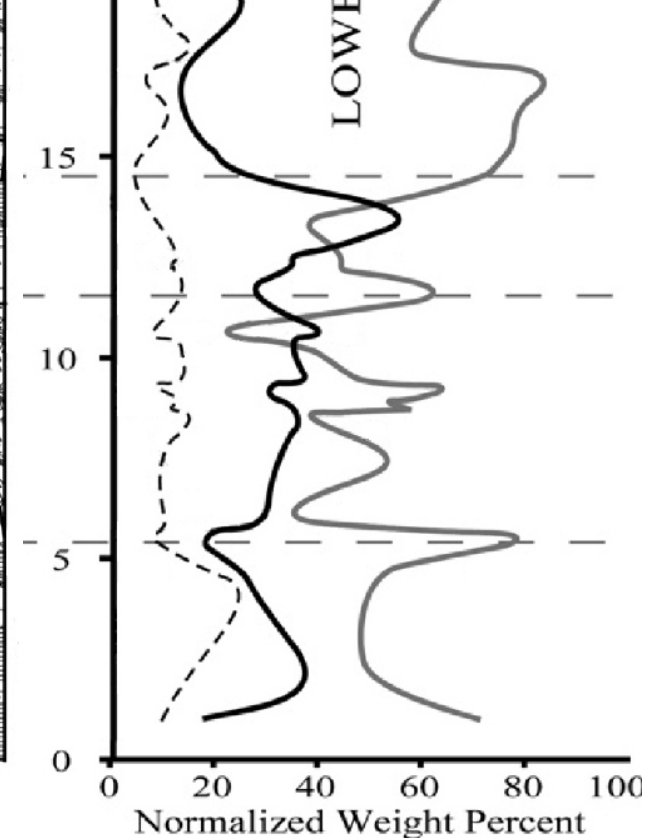

Ross et al., Fig. 4 


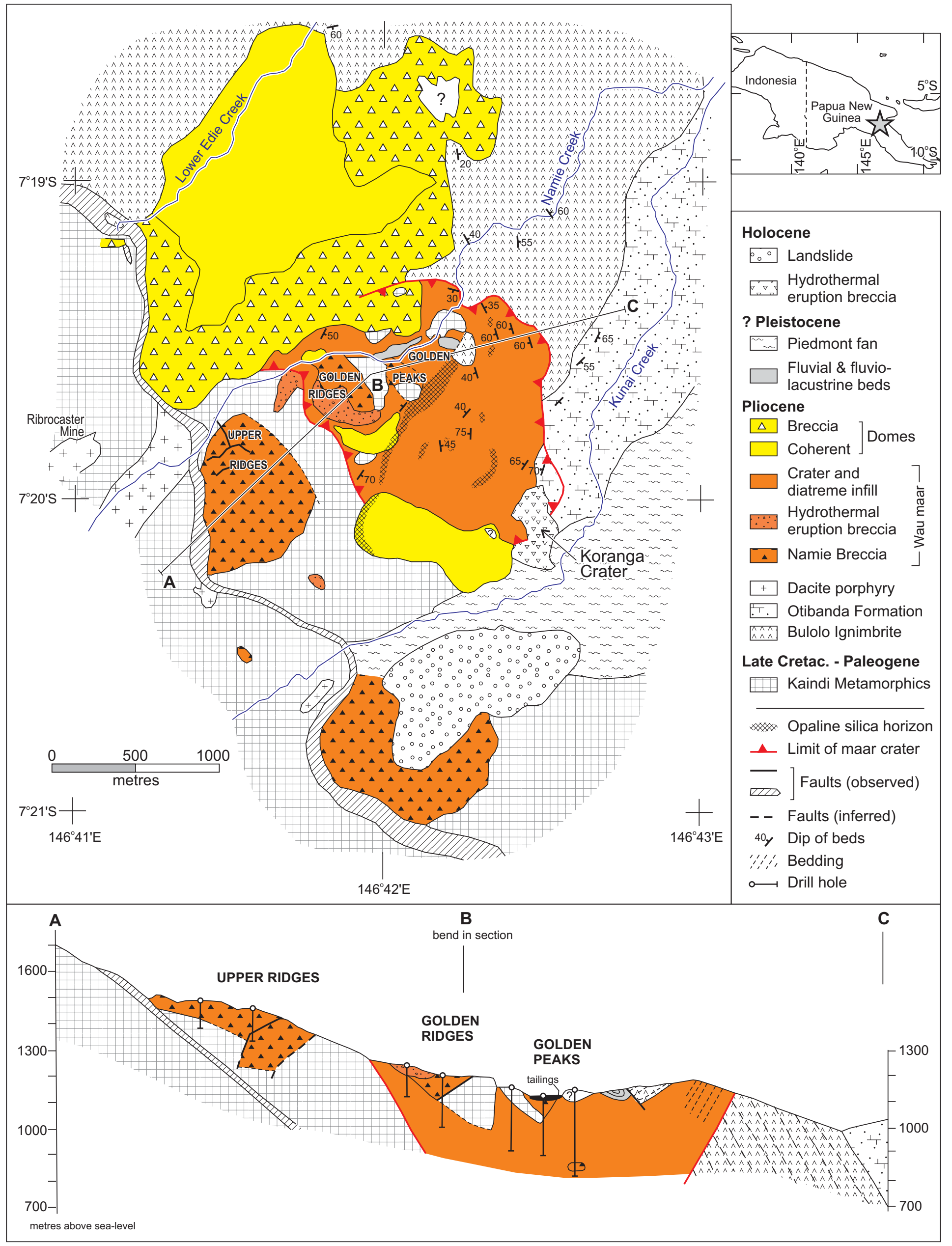

Ross et al., Fig. 5 
a

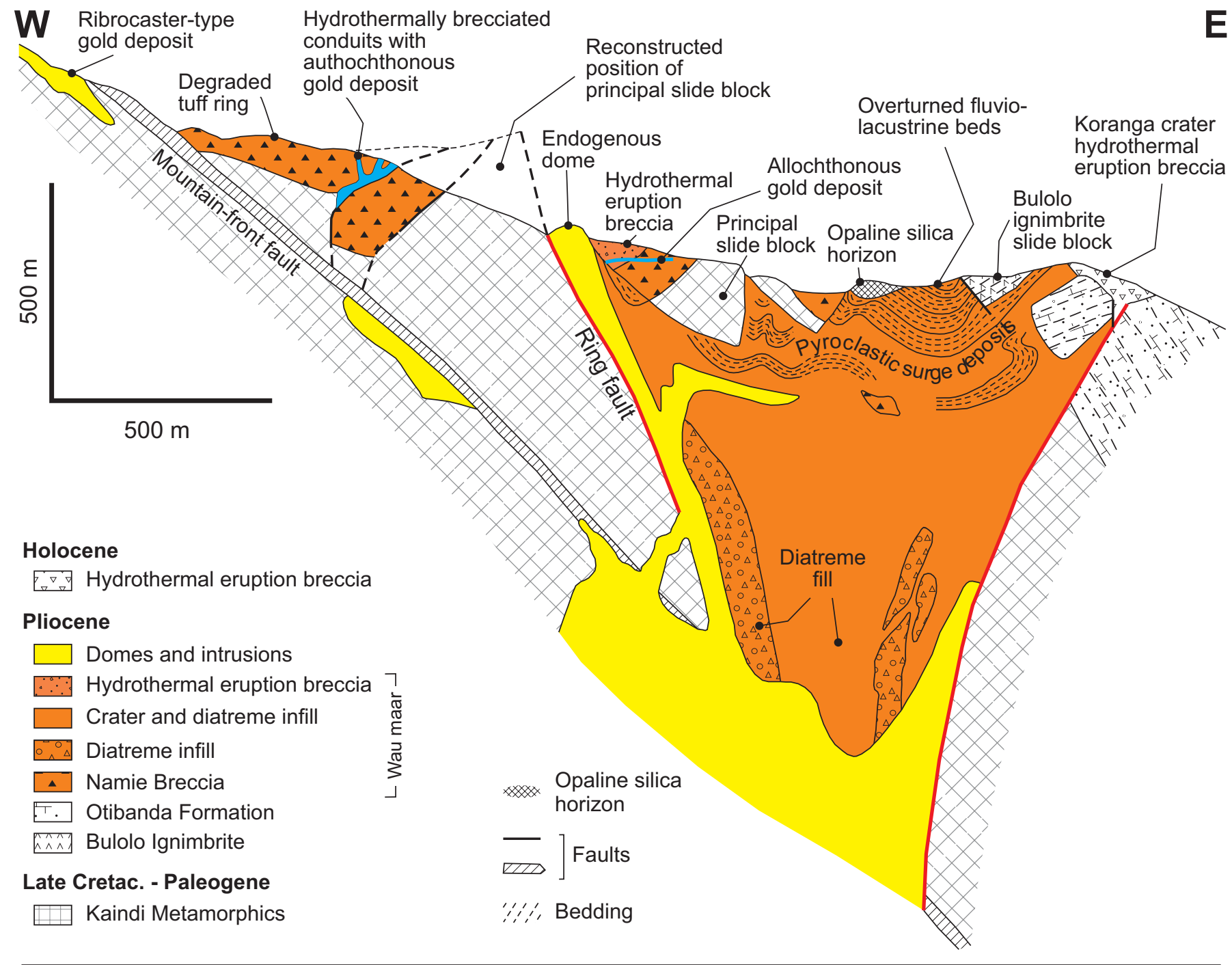

b $\mathbf{W}$

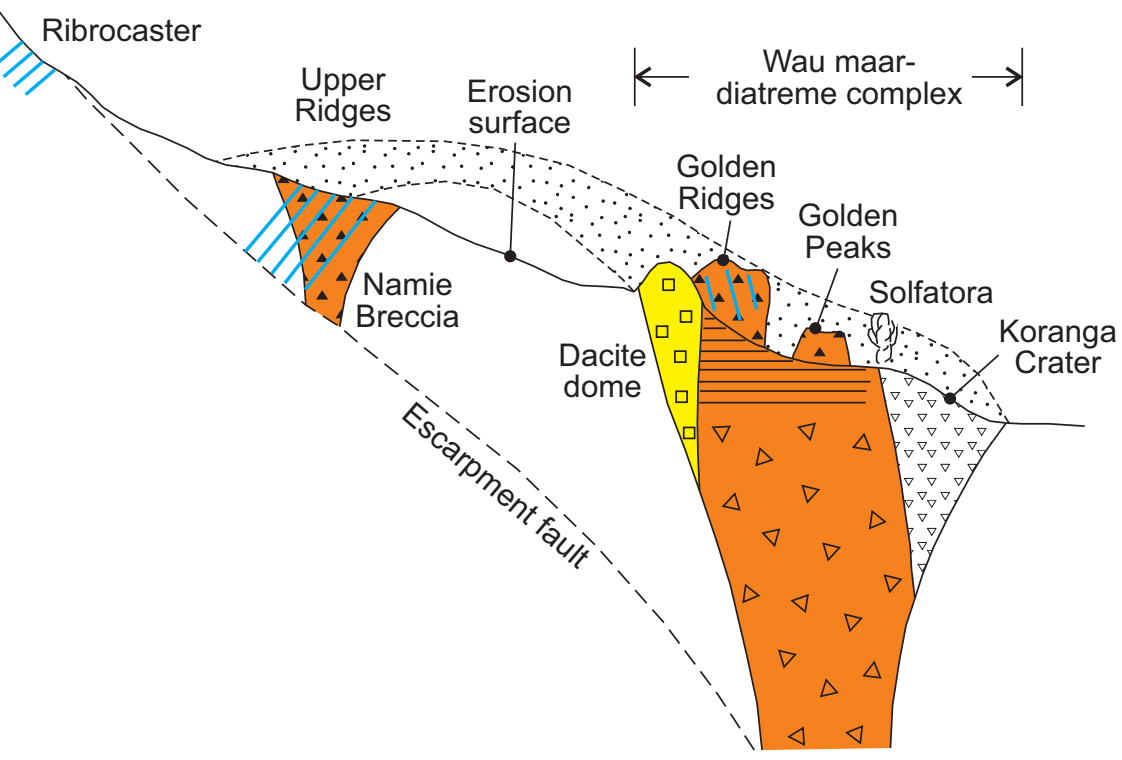

E

Ross et al., Fig. 6 


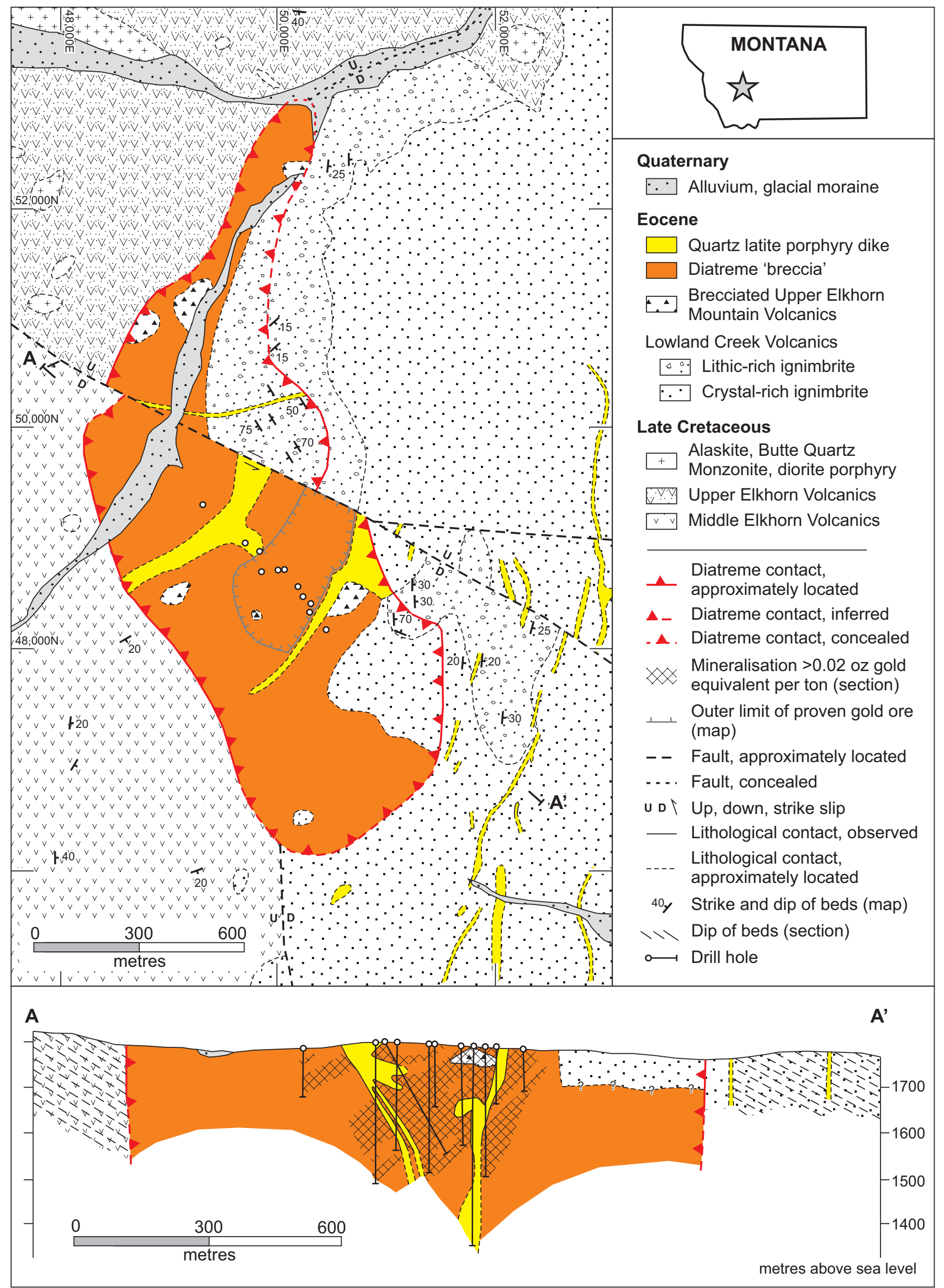

Ross et al., Fig. 7 


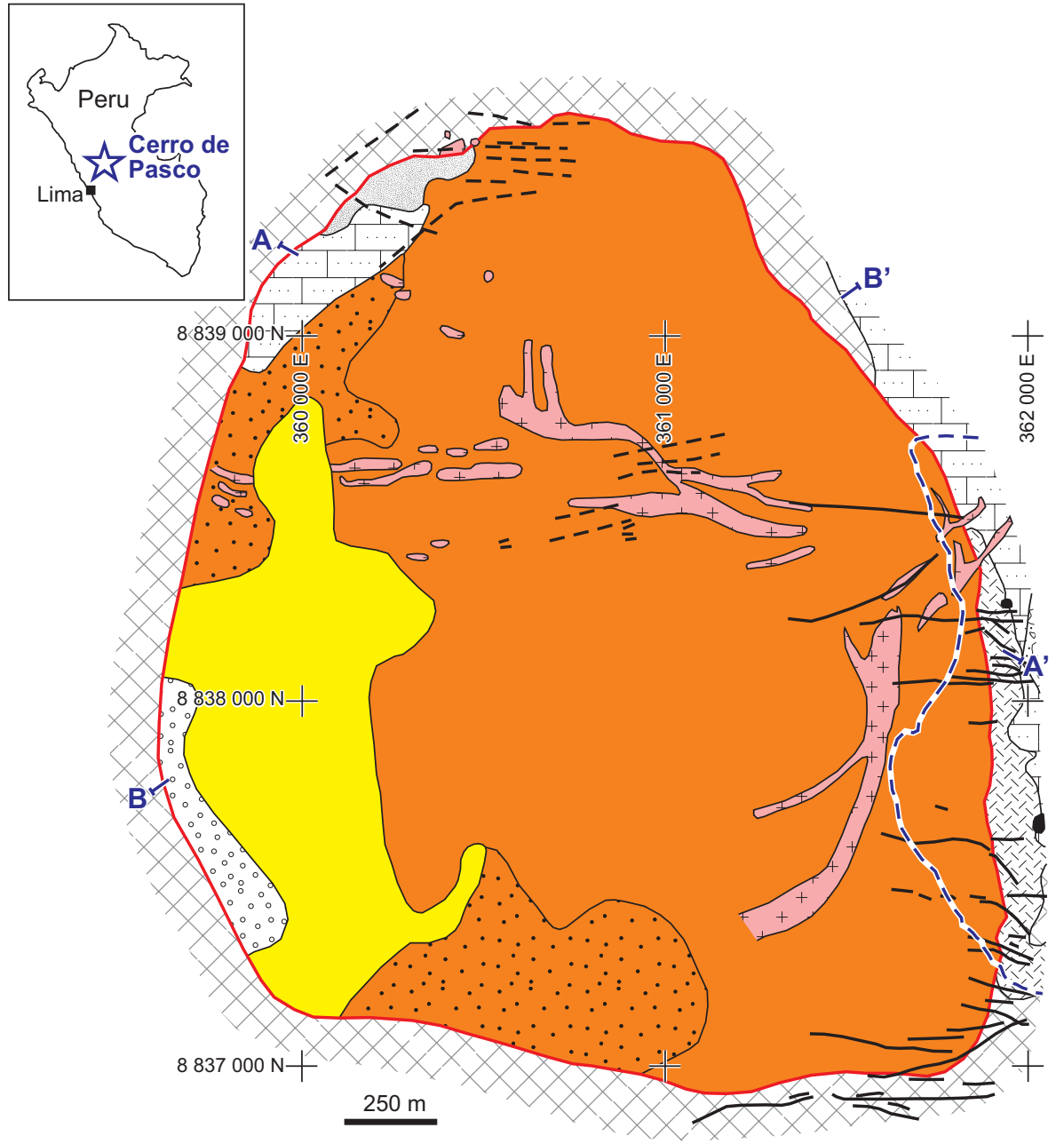

A

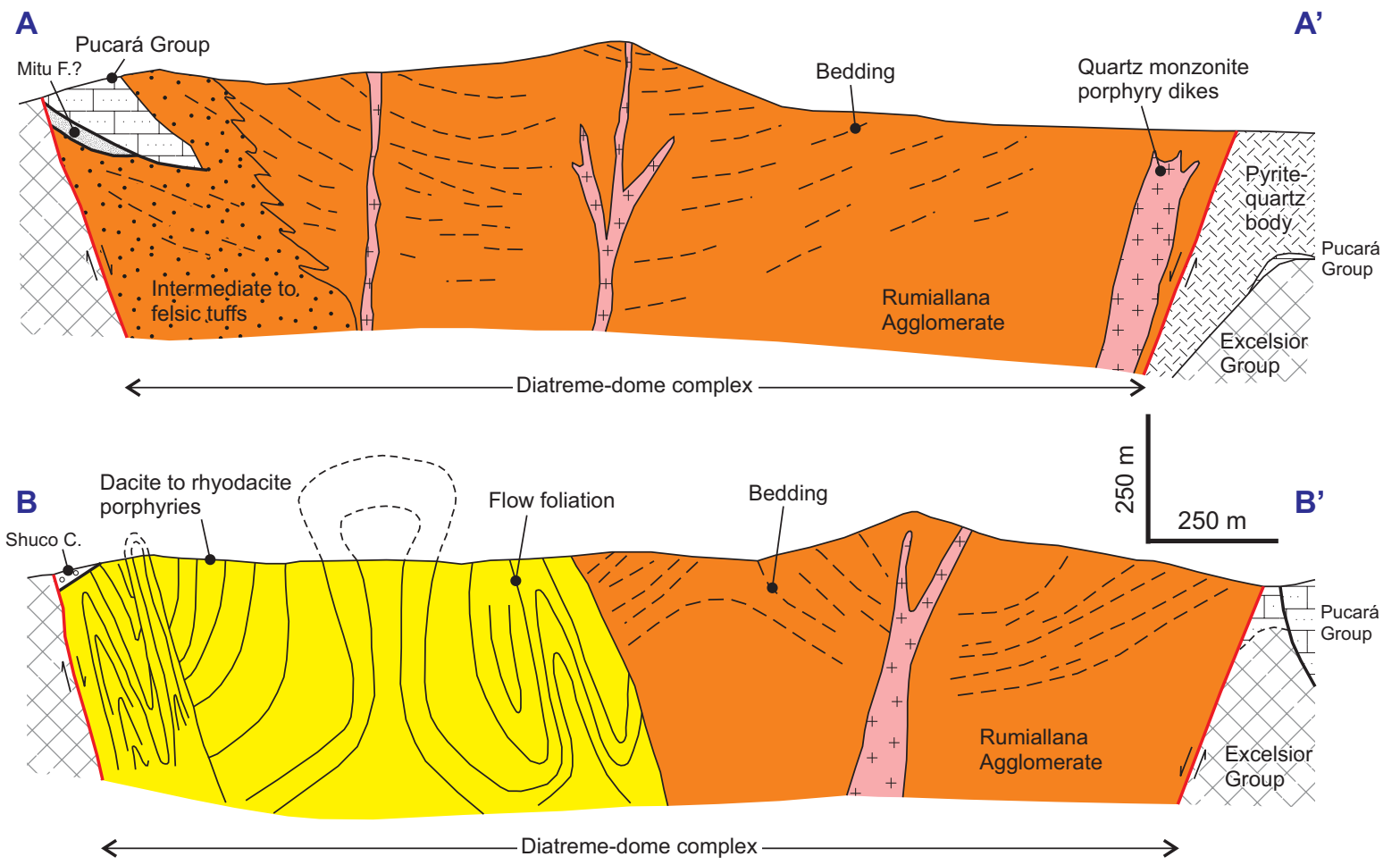

\section{Mineralisation}

Western Cu-Ag-(Au$\mathrm{Zn}-\mathrm{Pb}$ ) enargite-pyrite veins

Pipe-like pyrrhotite bodies

Pyrite-quartz body

\section{Mid-Miocene}

B.: Polymictic breccia

Quartz monzonite porphyry dikes

Dacite to rhyodacite porphyries (showing domal structures)

Intermediate to felsic tuffs

Diatreme 'breccia'

(Rumiallana

Agglomerate)

\section{Pre-Miocene rocks}

$\because \circ$ Eocene Shuco Conglomerate

Upper Triassic-Lower Jurassic Pucará Group

Permian-Triassic Mitu

Formation

Devonian Excelsior Group

Border of diatremedome complex

Fault and fracture-

- controlled veins

- - Contour of open pit

\section{$A^{\prime}$}



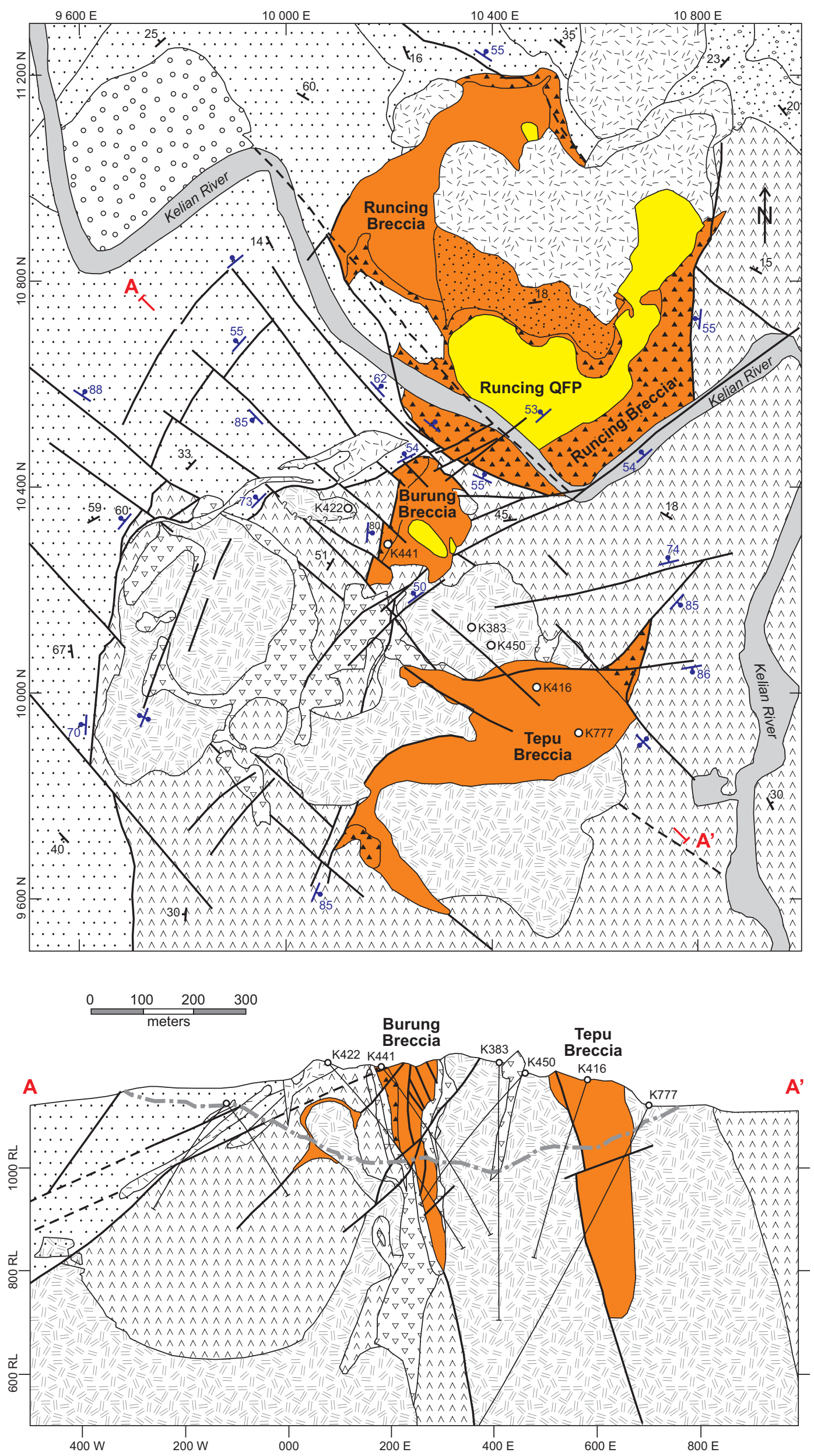

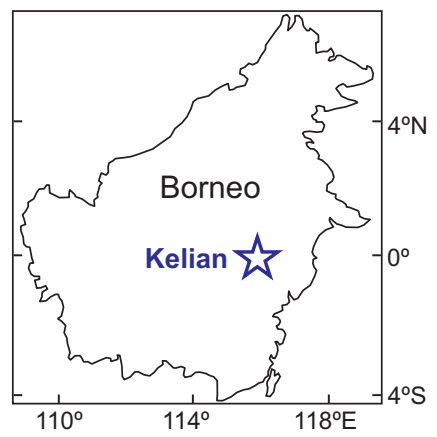

Quaternary

ए० Alluvium

Pliocene-Pleistocene

Mafic volcanic rocks, dikes, sediments

\section{Miocene}

C facies: polymict and monomic hydrothermally cemented breccias

$\therefore$ B facies: stratified polymict carbonaceous 'breccia'

A facies: polymict

carbonaceous 'breccias' (undifferentiated)

A facies: monomict

$\triangle$ carbonaceous mudstoneand sandstone-clast breccias

QFP rhyolite

Andesite

\section{Eocene-Oligocene}

$\square$ Carbonaceous and other sedimentary rocks

\section{Eocene}

Mudstone, sandstone conglomerate

\section{Upper Cretaceous}

$\Lambda \wedge \wedge$ Felsic volcaniclastic rocks

_ Fault, defined

- - Fault, approximate

40y Strike and dip of beds

${ }^{86}$ Strike and dip of faults

$\mathrm{O}_{\mathrm{K} 477}$ Selected drill holes (colars, map)

$\longrightarrow$ Drill holes (cross-section)

- Open pit outline (section only) 

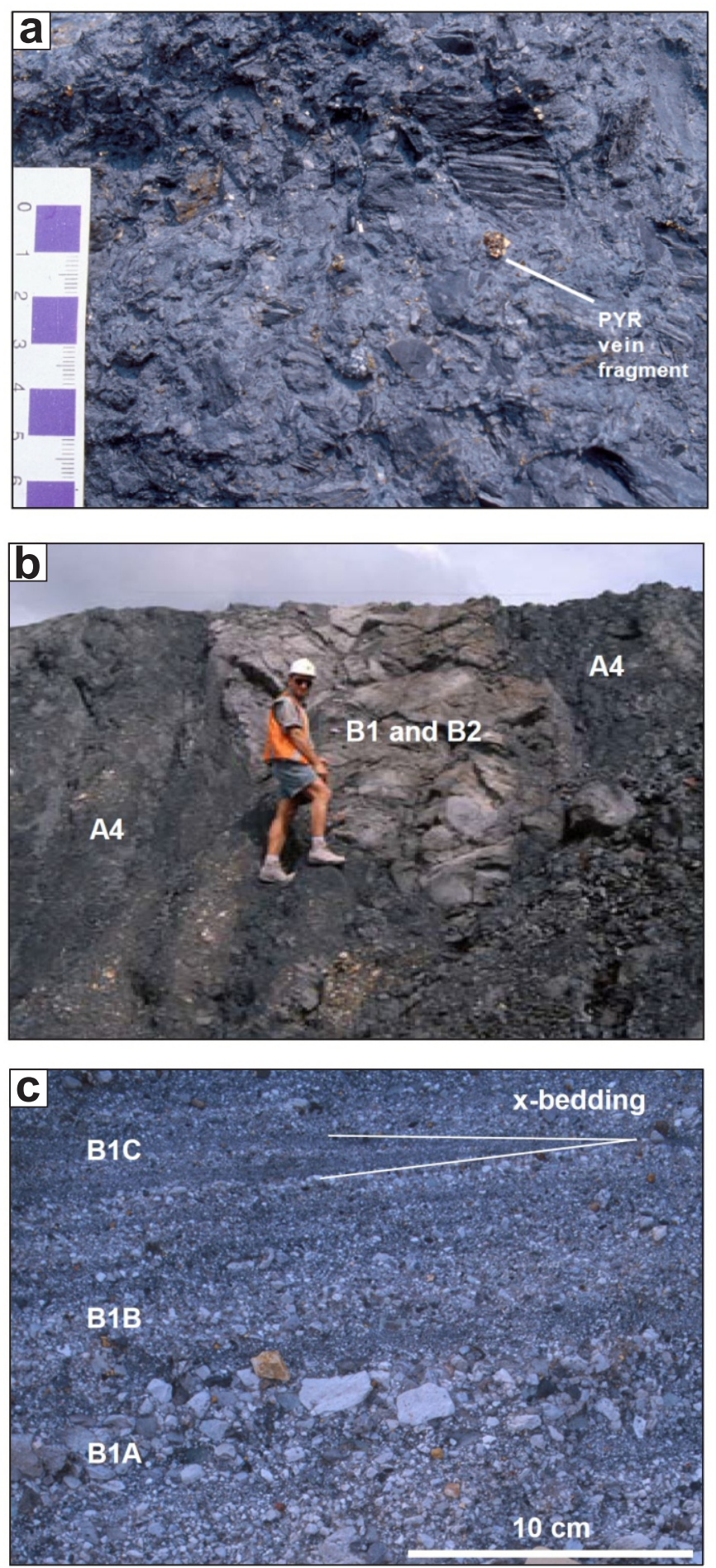
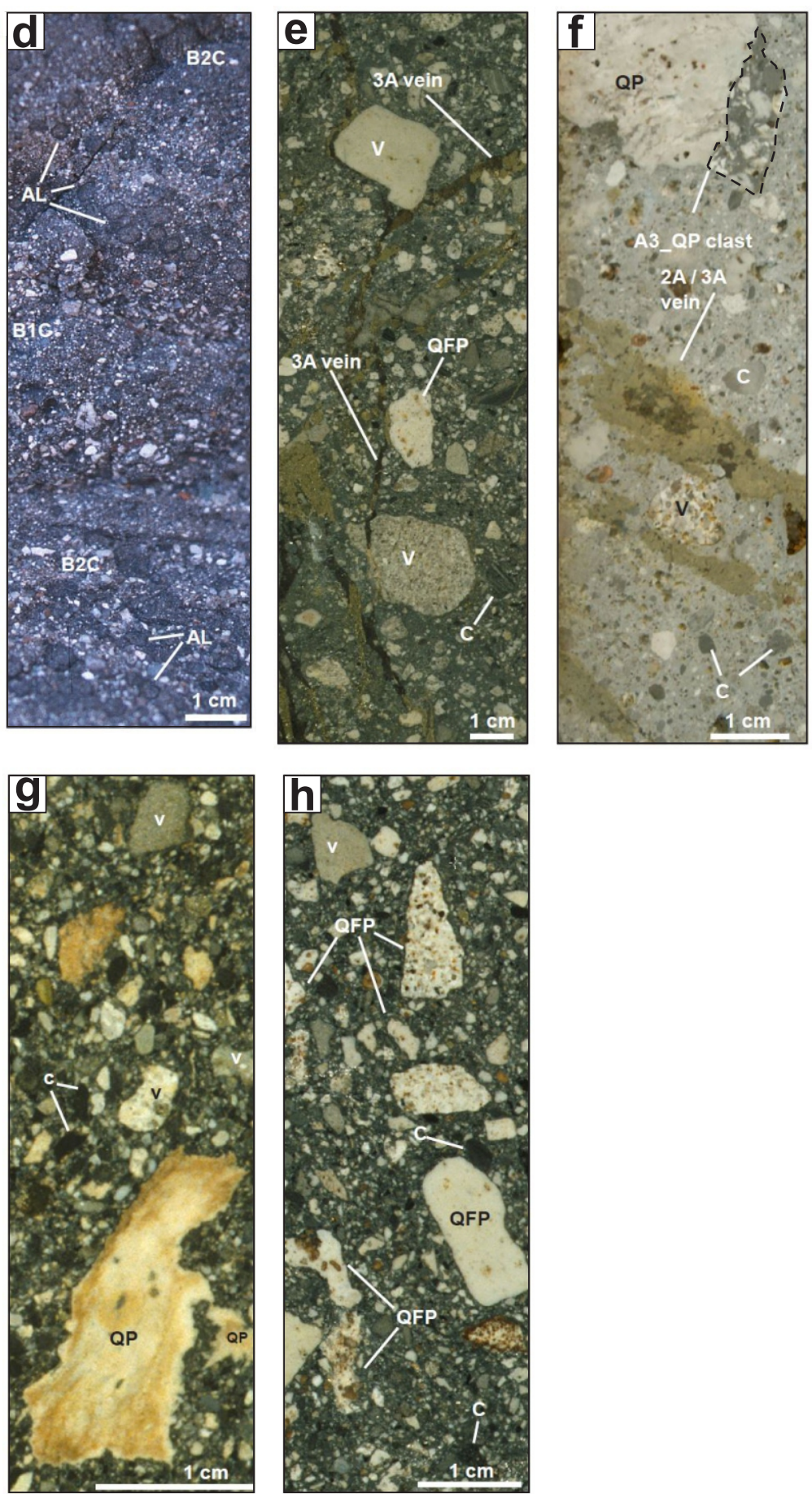

Ross et al., Fig. 10 


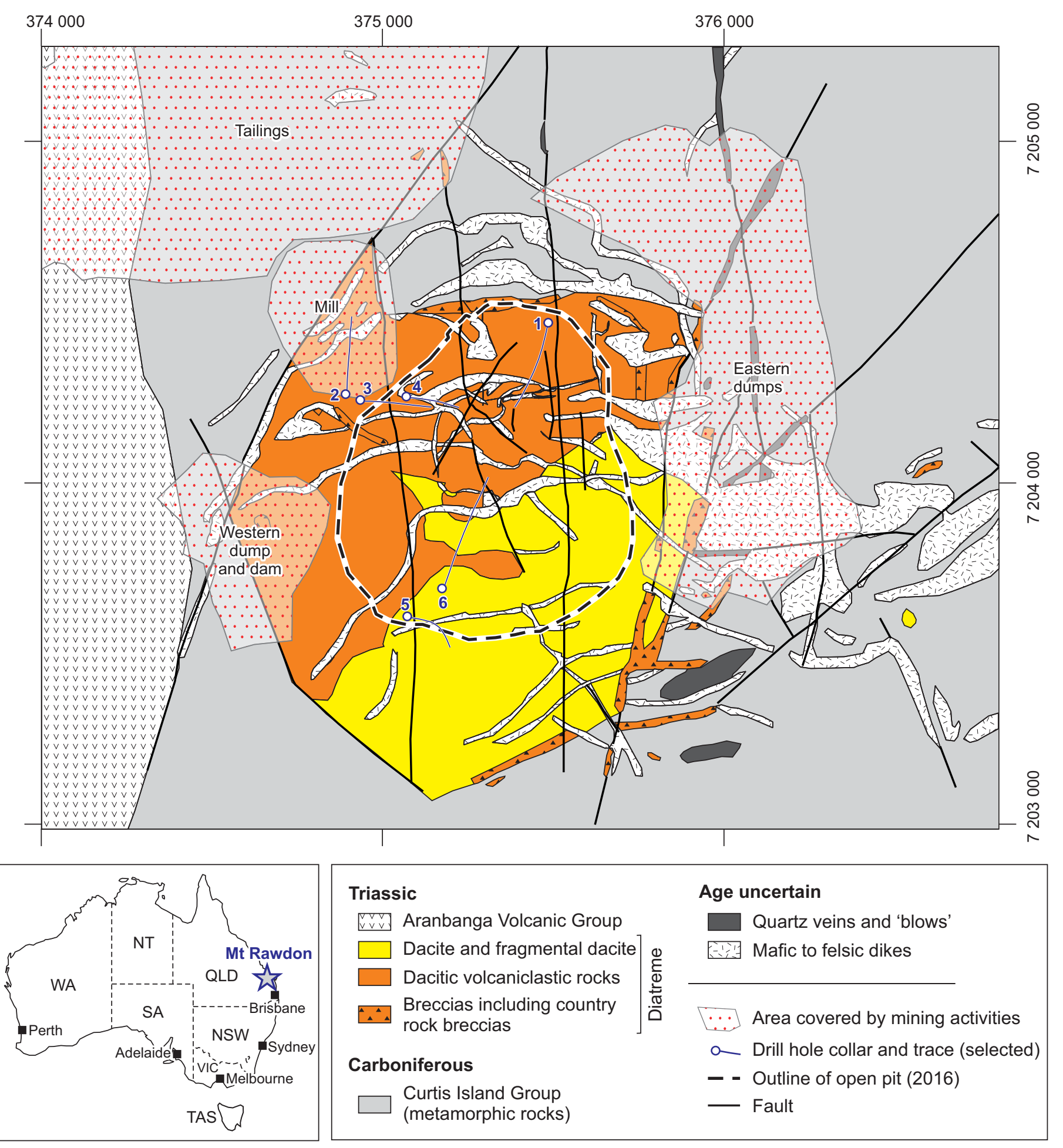

Ross et al., Fig. 11 

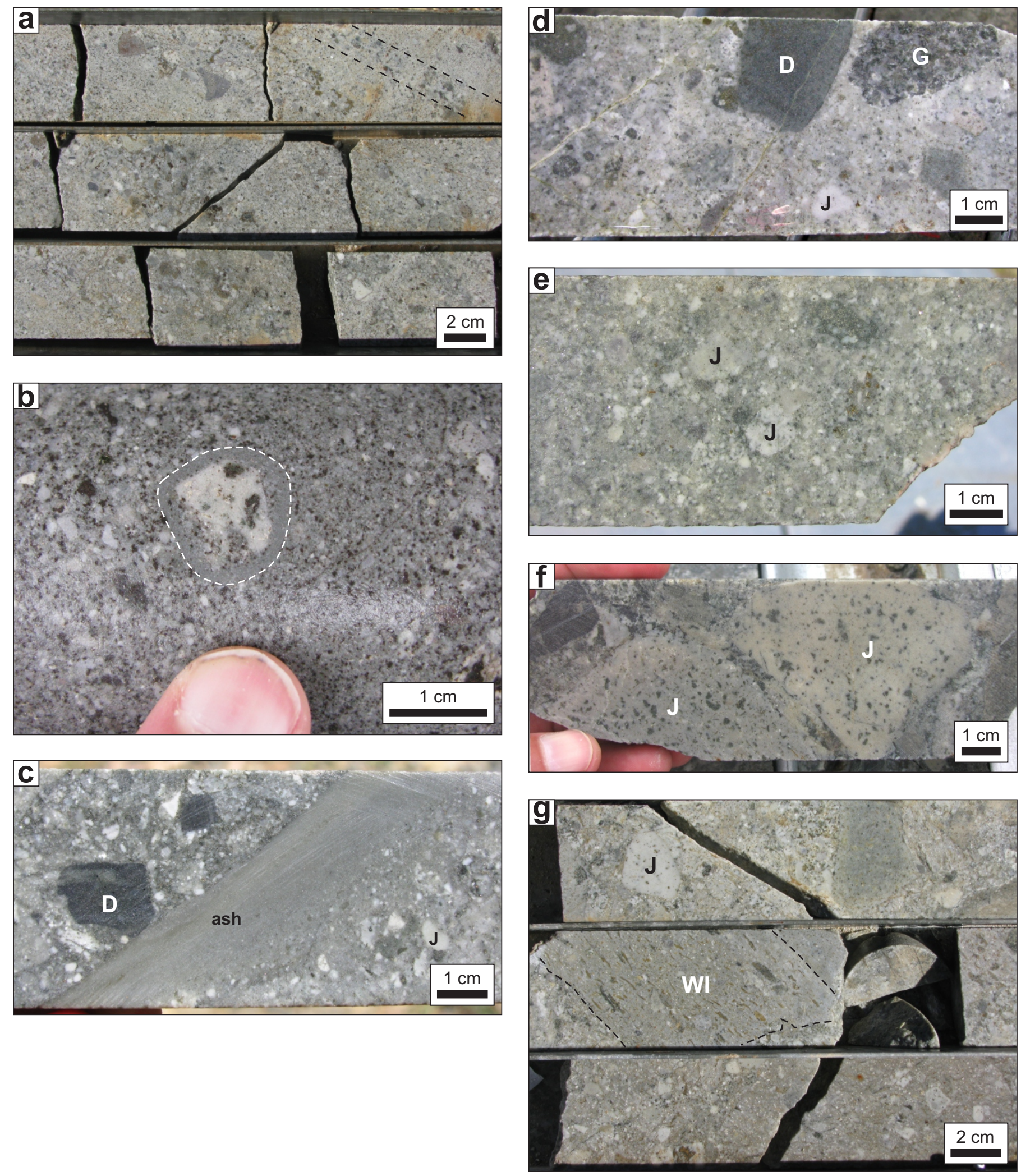

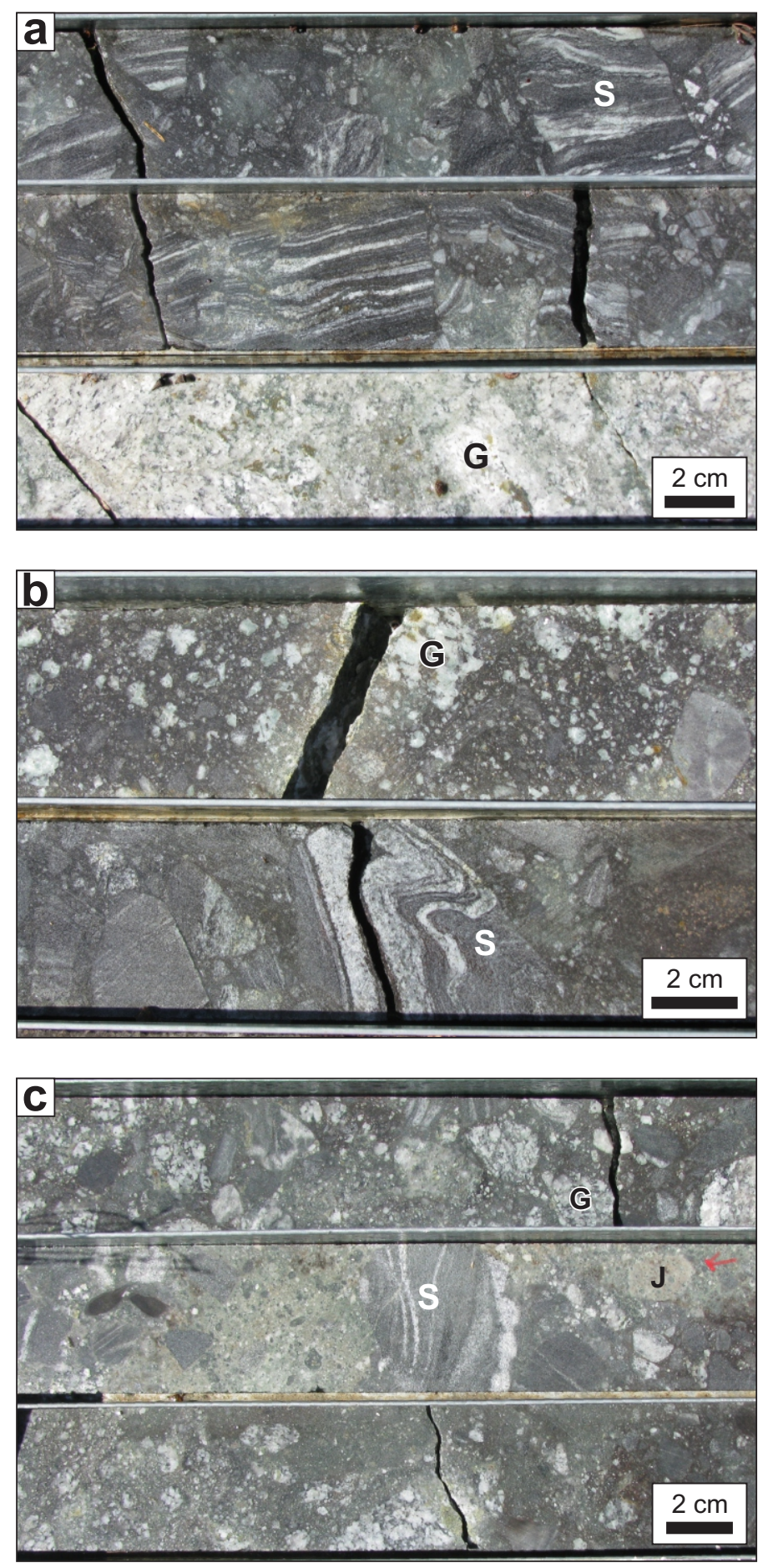

Ross et al., Fig. 13 

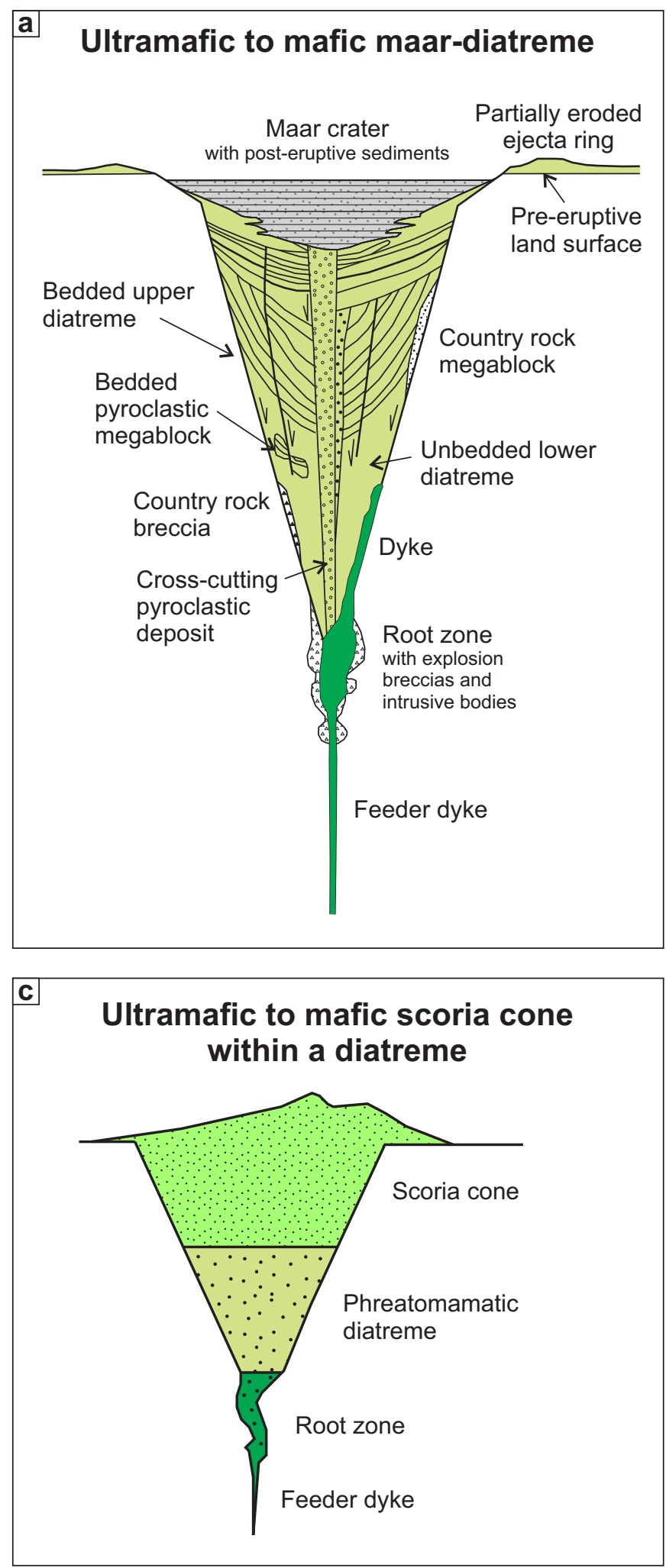

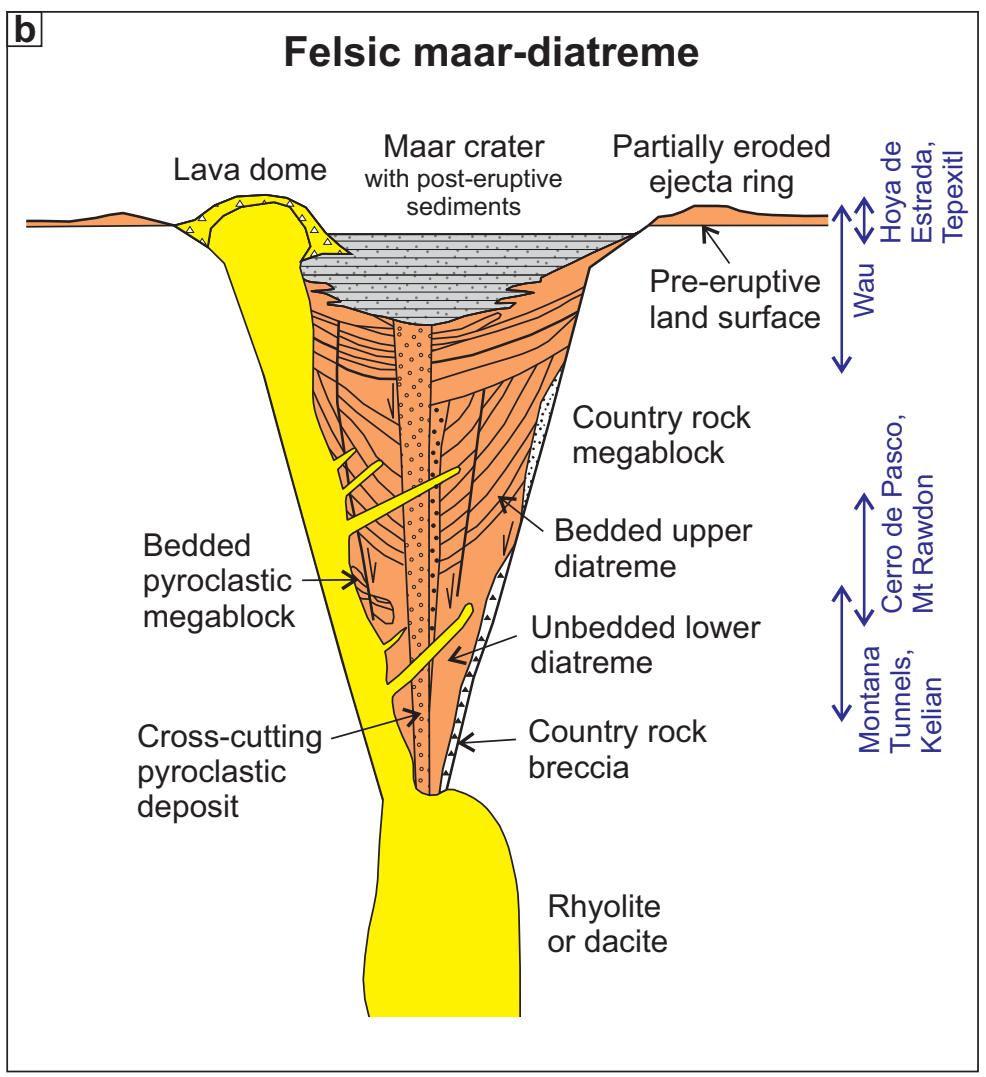

\section{d Felsic maar, tuff ring or tuff cone with lava flow or dome}

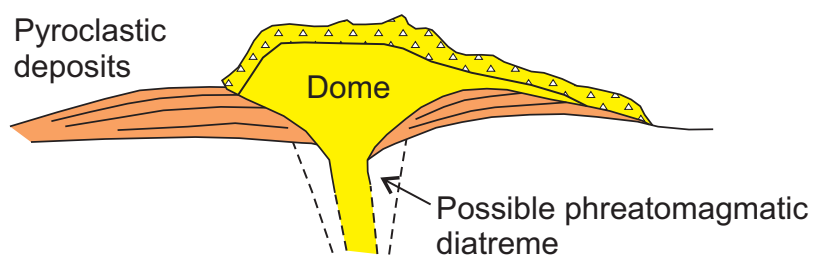


Ross et al., felsic maar-diatreme review

\section{Supplementary material}

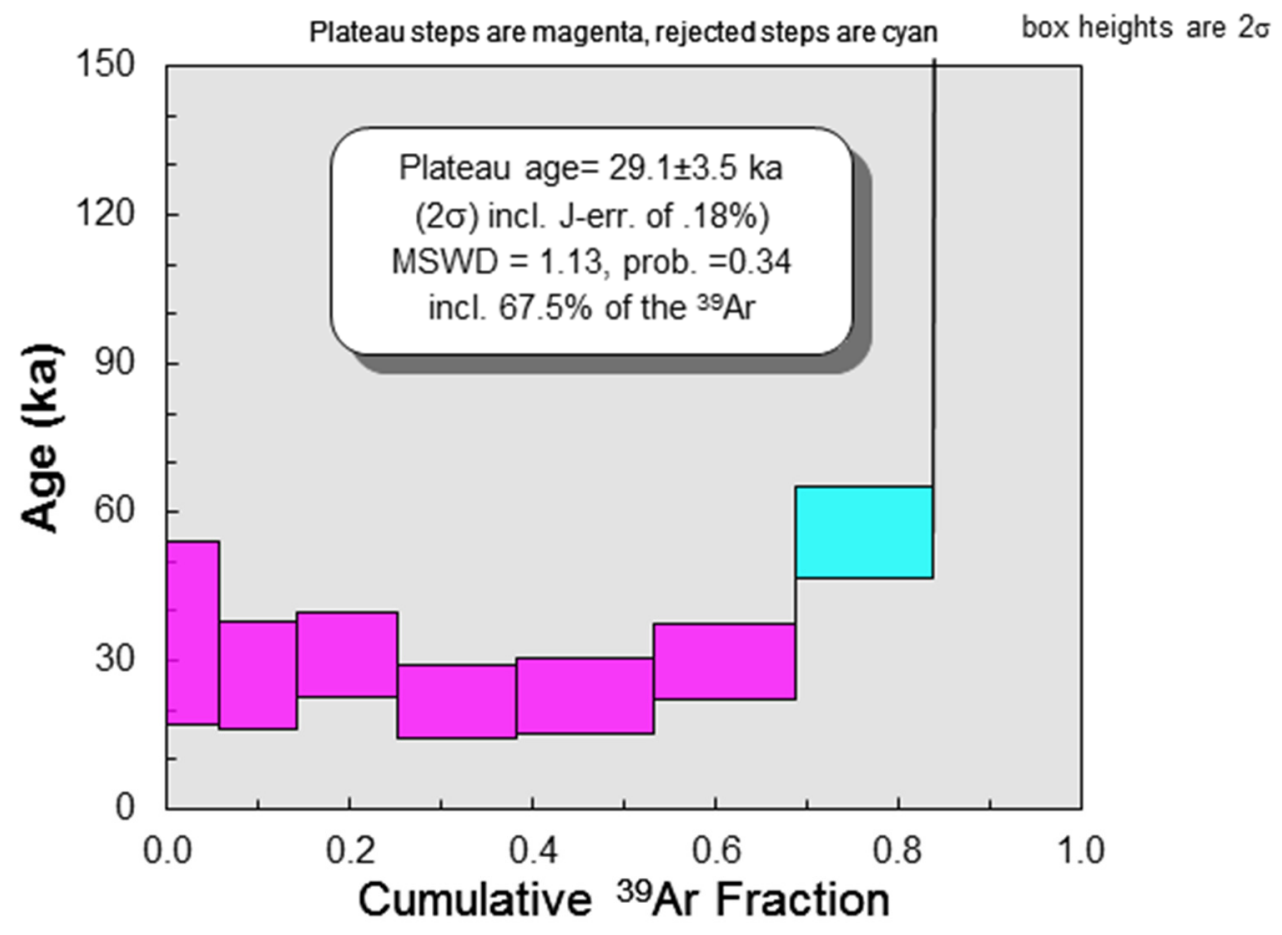

Figure S1: Ar-Ar dating results for the Tepexitl tuff ring. See main text for sample information and methods. 
Table 1. Summary of some important features of the seven reviewed localities.

\begin{tabular}{|c|c|c|c|c|c|c|c|}
\hline \multirow[t]{2}{*}{ Volcano } & \multirow[t]{2}{*}{ Age } & \multirow[t]{2}{*}{ Host rocks } & \multicolumn{2}{|c|}{ - - - - - Crater - - - - - } & \multicolumn{3}{|c|}{ - - - - - - Ejecta ring - - - - - - } \\
\hline & & & Dimensions & Deposits & Thickness & $\begin{array}{c}\text { Lateral } \\
\text { extent }\end{array}$ & Deposits \\
\hline Hoya de Estrada & $\begin{array}{l}0.18 \pm \\
0.03 \mathrm{Ma}\end{array}$ & Andesite lavas & $\begin{array}{l}1.23 \mathrm{~km} \text { diameter; } \\
\text { depth is } 60 \mathrm{~m} \text { below } \\
\text { rim }\end{array}$ & $?$ & $>27 \mathrm{~m}$ & $1.8 \mathrm{~km}$ & Pyroclastic fall and surge deposits \\
\hline Tepexitl & $\begin{array}{l}29.1 \pm 3.5 \\
\mathrm{ka}\end{array}$ & $\begin{array}{l}\text { Reworked } \\
\text { Quaternary unconsolidated material, } \\
\text { limestone basement }\end{array}$ & $\begin{array}{l}1 \mathrm{~km} \text { diameter; crater } \\
\text { floor is } 20 \mathrm{~m} \text { below } \\
\text { local terrain }\end{array}$ & $?$ & $50+m$ & $1.5 \mathrm{~km}$ & Pyroclastic fall and surge deposits \\
\hline Wau & $\sim 2.4 \mathrm{Ma}$ & $\begin{array}{l}\text { Metamorphics, ignimbrite, sedimentary } \\
\text { rocks }\end{array}$ & $\begin{array}{l}1.4 \mathrm{~km} \text { (eroded crater } \\
\emptyset)\end{array}$ & $\begin{array}{l}\text { Reworked pyroclastics, grits, } \\
\text { sandstones, laminated mudstones } \\
\text { local travertine \& sinter }\end{array}$ & $200 \mathrm{~m}^{\text {(a) }}$ & $\begin{array}{l}1.6 \mathrm{~km} \\
\varnothing\end{array}$ & $\begin{array}{l}\text { Bedded pyroclastics, including } \\
\text { surge deposits }\end{array}$ \\
\hline Montana Tunnels & $50 \pm 2 \mathrm{Ma}$ & $\begin{array}{l}\text { Felsic ignimbrites, andesitic sediments, } \\
\text { felsic intrusions }\end{array}$ & $\mathrm{n} / \mathrm{a}$ & $\mathrm{n} / \mathrm{a}$ & $\mathrm{n} / \mathrm{a}$ & $\mathrm{n} / \mathrm{a}$ & $\begin{array}{l}\text { (b) Bedded pyroclastics, similar to } \\
\text { but finer-grained than diatreme } \\
\text { infill. Cross-beds, dune forms }\end{array}$ \\
\hline Cerro de Pasco & $\sim 15.4 \mathrm{Ma}$ & $\begin{array}{l}\text { Shale, phylite, quartzite, sandstone, } \\
\text { conglomerate, limestone, dolomite }\end{array}$ & $\mathrm{n} / \mathrm{a}$ & $\mathrm{n} / \mathrm{a}$ & $\mathrm{n} / \mathrm{a}$ & $\mathrm{n} / \mathrm{a}$ & $\begin{array}{l}\text { (b) Dacitic tuff with cross-bedding } \\
\text { and accretionary lapilli }\end{array}$ \\
\hline $\begin{array}{l}\text { Kelian (3 } \\
\text { diatremes: Runcing; } \\
\text { Burung; Tepu) }\end{array}$ & $\begin{array}{l}\sim 19.8- \\
19.5 \mathrm{Ma}\end{array}$ & $\begin{array}{l}\text { Felsic volcanic rocks, sedimenrary rocks } \\
\text { andesitic intrusions }\end{array}$ & $\mathrm{n} / \mathrm{a}$ & $\mathrm{n} / \mathrm{a}$ & $\mathrm{n} / \mathrm{a}$ & $\mathrm{n} / \mathrm{a}$ & $\begin{array}{l}\text { (b) Planar- to cross-bedded, dune } \\
\text { structures, soft-sediment } \\
\text { deformation, accretionary lapilli }\end{array}$ \\
\hline Mt Rawdon & $\sim 230 \mathrm{Ma}$ & $\begin{array}{l}\text { Metasediments, granitoid intrusions at } \\
\text { least around three sides, dominantly } \\
\text { andesitic? volcanics to the W }\end{array}$ & $\mathrm{n} / \mathrm{a}$ & $\mathrm{n} / \mathrm{a}$ & $\mathrm{n} / \mathrm{a}$ & $\mathrm{n} / \mathrm{a}$ & $\mathrm{n} / \mathrm{a}$ \\
\hline
\end{tabular}

NOTES

(a) = The great thickness of the 'Namie Breccia' at Wau is thought to be "partly a consequence of repetition of the succession by flat faults" (Sillitoe et al. 1984)

(b) = preserved in megablocks within the diatreme 
Table 1 (cont.)

\begin{tabular}{|c|c|c|c|c|c|c|c|c|}
\hline \multirow[t]{2}{*}{ Volcano } & \multicolumn{5}{|c|}{$\begin{array}{l}-\ldots \\
\end{array}$} & \multicolumn{2}{|c|}{ 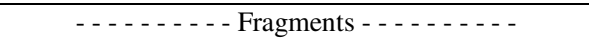 } & \multirow{2}{*}{$\begin{array}{l}\text { Domes, plugs and } \\
\text { dikes }\end{array}$} \\
\hline & Angle of walls & Depth $^{(c)}$ & Size ${ }^{(c)}$ & $\begin{array}{l}\text { Preserved } \\
\text { volume }\end{array}$ & Infill & Lithic & Juvenile & \\
\hline $\begin{array}{l}\text { Hoya de } \\
\text { Estrada }\end{array}$ & $\mathrm{n} / \mathrm{a}$ & $\mathrm{n} / \mathrm{a}$ & $\mathrm{n} / \mathrm{a}$ & $\mathrm{n} / \mathrm{a}$ & $\mathrm{n} / \mathrm{a}$ & $\begin{array}{l}0-80 \% \text { (andesite, } \\
\text { basalt, scoria) }\end{array}$ & $\begin{array}{l}\text { Stony rhyolite to } \\
\text { rhyolitic 'pumice' (5- } \\
55 \% \text { vesicles) > dacite } \\
\text { pumice, accretionary } \\
\text { lapilli }\end{array}$ & Not preserved \\
\hline Tepexitl & $\mathrm{n} / \mathrm{a}$ & $\mathrm{n} / \mathrm{a}$ & $\mathrm{n} / \mathrm{a}$ & $\mathrm{n} / \mathrm{a}$ & $\mathrm{n} / \mathrm{a}$ & $\begin{array}{l}27 \% \text { on average } \\
\text { (andesite, basalt, } \\
\text { altered rhyolite, } \\
\text { pumice, minor } \\
\text { limestone, some } \\
\text { xenocrysts) }\end{array}$ & $\begin{array}{l}\text { Rhyolite, } \\
\text { stony }>\text { obsidian (dense), } \\
\text { rare pumice; } \\
\text { accretionary lapilli }\end{array}$ & Not preserved \\
\hline Wau & $\begin{array}{l}50-70^{\circ} \text { inward } \\
\text { dip }\end{array}$ & $>300 \mathrm{~m}$ & See crater & $\mathrm{n} / \mathrm{a}$ & $\begin{array}{l}\text { Bedded phreatomagmatic deposits (fall and } \\
\text { surge) }\end{array}$ & $\begin{array}{l}\text { Metamorphics, } \\
\text { ignimbrite }\end{array}$ & $\begin{array}{l}\text { Dacite porphyry, } \\
\text { accretionary lapilli }\end{array}$ & $\begin{array}{l}\text { Two late-stage } \\
\text { domes just outside } \\
\text { the crater }\end{array}$ \\
\hline $\begin{array}{l}\text { Montana } \\
\text { Tunnels }\end{array}$ & Near vertical & $>310 \mathrm{~m}$ & $\begin{array}{l}2.1 \mathrm{~km} ; 1 \\
\mathrm{~km}^{2}\end{array}$ & $0.8 \mathrm{~km}^{3}$ & $\begin{array}{l}\text { Non-bedded, matrix-rich. Some cross-cutting } \\
\text { zones with finer-grained or coarser-grained } \\
\text { material. Megablocks of host rocks and ejecta } \\
\text { ring deposits. Country rock breccias. }\end{array}$ & $\begin{array}{l}\text { Felsic ignimbrite, } \\
\text { andesitic sediments, } \\
\text { quartz monzonite, } \\
\text { alaskite, aplite }\end{array}$ & $\begin{array}{l}\text { Quartz latite porphyry, } \\
\text { quartz, feldspar, biotite }\end{array}$ & $\begin{array}{l}\text { Quartz latite } \\
\text { porphyry dikes up to } \\
90 \text { m wide }\end{array}$ \\
\hline $\begin{array}{l}\text { Cerro de } \\
\text { Pasco }\end{array}$ & $\begin{array}{l}\text { Steep contacts, } \\
\text { faulted; sharp to } \\
1 \mathrm{~m} \text { thick } \\
\text { gradational } \\
\text { breccias }\end{array}$ & $>1 \mathrm{~km}$ & $\begin{array}{l}2.0-2.5 \mathrm{~km} \\
\varnothing\end{array}$ & $3.6 \mathrm{~km}^{3}$ & $\begin{array}{l}\text { Two facies in gradational contact: 1) lithic-rich, } \\
\text { heterolithic, matrix-supported, non-bedded to } \\
\text { bedded volcaniclastics rocks, and 2) crystal-rich } \\
\text { (quartz, feldspar and biotite), glass-shard bearing, } \\
\text { intermediate to felsic, white to gray and } \\
\text { commonly thinly bedded, volcaniclastic rocks } \\
\text { with rare eutaxitic textures. Infill contains } \\
\text { megablocks derived from ejecta ring and country } \\
\text { rock. }\end{array}$ & $\begin{array}{l}>90 \% \text { of clasts. } \\
\text { phylite, limestone, } \\
\text { chert }\end{array}$ & $\begin{array}{l}5-10 \%, \text { highly altered } \\
\text { porphyritic igneous, } \\
\text { possibly juvenile, clasts }\end{array}$ & $\begin{array}{l}\text { Dacite to rhyolite } \\
\text { porphyries }\end{array}$ \\
\hline $\begin{array}{l}\text { Kelian (3 } \\
\text { diatremes: } \\
\text { Runcing; } \\
\text { Burung; } \\
\text { Tepu) }\end{array}$ & $\begin{array}{l}\text { Steep, some } \\
\text { margins marked } \\
\text { by country rock } \\
\text { breccias }\end{array}$ & $\begin{array}{l}>500 \\
\mathrm{~m} ; \\
>450 \\
\mathrm{~m} ; \\
>500 \mathrm{~m}\end{array}$ & $\begin{array}{l}750 \times 750 \mathrm{~m} \\
275 \times 175 \mathrm{~m} \\
<750 \mathrm{~m}\end{array}$ & $\begin{array}{l}0.3 \mathrm{~km}^{3} \\
\mathrm{n} / \mathrm{a} \\
0.2 \mathrm{~km}^{3}\end{array}$ & $\begin{array}{l}\text { Pipe in pipe structures. Dominant infill is non- } \\
\text { bedded, poorly sorted, polymictic, juvenile-clast } \\
\text { bearing pyroclastic rocks with rare megablocks of } \\
\text { ejecta ring deposits. Less abundant rocks with } \\
\text { textures similar to blocky and fluidal peperites }\end{array}$ & $\begin{array}{l}\text { Carbonaceous } \\
\text { mudstone, fine } \\
\text { sandstone and coherent } \\
\text { andesite }\end{array}$ & $\begin{array}{l}5-30 \% \text { of clasts; dense } \\
\text { rhyolite (quartz and } \\
\text { quartz-feldspar } \\
\text { porphyritic), locally } \\
\text { abundant accretionary } \\
\text { lapilli }\end{array}$ & $\begin{array}{l}\text { Quartz feldspar } \\
\text { porphyry and quartz } \\
\text { porphyry plugs }\end{array}$ \\
\hline Mt Rawdon & $\begin{array}{l}\text { In places } \\
\text { marked by } \\
\text { country rock } \\
\text { breccias, 5-50 } \\
\text { thick, with steep } \\
\text { dips }\end{array}$ & $>915 \mathrm{~m}$ & $\begin{array}{l}1.45 \times 1.39 \\
\mathrm{~km}\end{array}$ & $0.9 \mathrm{~km}^{3}$ & $\begin{array}{l}\text { Upper } ~ 150 \mathrm{~m} \text { bedded (planar bedded, cross- } \\
\text { bedded, dune structures, ballistic sag structures, } \\
\text { possible megablocks); lower sequence non- } \\
\text { bedded to thickly bedded, poorly sorted, } \\
\text { polymictics lapilli tuffs. Possible cross-cutting } \\
\text { pyroclastic zones }\end{array}$ & $\begin{array}{l}<10 \% \text { to very } \\
\text { abundant; metaseds, } \\
\text { granite, dark aphyric } \\
\text { clasts (basalt or } \\
\text { metaseds) and rare } \\
\text { ignimbrite clasts }\end{array}$ & $\begin{array}{l}\text { Generally more } \\
\text { abundant than lithic } \\
\text { clasts; dacite } \\
\text { (porphyritic to aphyric; } \\
\text { non-vesicular), rare } \\
\text { accretionary lapilli }\end{array}$ & $\begin{array}{l}\text { Half the diatreme } \\
\text { occupied by dacitic } \\
\text { (porphyry) } \\
\text { intrusions; numerous } \\
\text { cross-cutting felsic } \\
\text { to intermediate dikes }\end{array}$ \\
\hline
\end{tabular}

NOTES

(c) = Depth relative to pre-mining surface, and size at pre-mining surface

(d) = This is the minimum preserved diatreme volume after natural erosion, calculated assuming a truncated cone with 70 degree walls for simplicity (see text for explanation) 